\title{
The middle ear muscles of the rat : morphological and functional aspects
}

Citation for published version (APA):

van den Berge, $H_{\text {. }}(1990)$. The middle ear muscles of the rat : morphological and functional aspects. [Doctoral Thesis, Maastricht University]. Maastricht University. https://doi.org/10.26481/dis.19900223hb

Document status and date:

Published: 01/01/1990

DOI:

10.26481/dis.19900223hb

Document Version:

Publisher's PDF, also known as Version of record

\section{Please check the document version of this publication:}

- A submitted manuscript is the version of the article upon submission and before peer-review. There can be important differences between the submitted version and the official published version of record.

People interested in the research are advised to contact the author for the final version of the publication, or visit the DOI to the publisher's website.

- The final author version and the galley proof are versions of the publication after peer review.

- The final published version features the final layout of the paper including the volume, issue and page numbers.

Link to publication

\footnotetext{
General rights rights.

- You may freely distribute the URL identifying the publication in the public portal. please follow below link for the End User Agreement:

www.umlib.nl/taverne-license

Take down policy

If you believe that this document breaches copyright please contact us at:

repository@maastrichtuniversity.nl

providing details and we will investigate your claim.
}

Copyright and moral rights for the publications made accessible in the public portal are retained by the authors and/or other copyright owners and it is a condition of accessing publications that users recognise and abide by the legal requirements associated with these

- Users may download and print one copy of any publication from the public portal for the purpose of private study or research.

- You may not further distribute the material or use it for any profit-making activity or commercial gain

If the publication is distributed under the terms of Article $25 \mathrm{fa}$ of the Dutch Copyright Act, indicated by the "Taverne" license above, 


\section{THE MIDDLE EAR MUSCLES OF THE RAT}

morphological and functional aspects 



\title{
THE MIDDLE EAR MUSCLES OF THE RAT
}

\section{morphological and functional aspects}

\author{
PROEFSCHRIFT
}

\author{
ter verkrijging van de graad van doctor \\ aan de Rijksuniversiteit Limburg te Maastricht, \\ op gezag van de Rector Magnificus, Prof. Dr. F.I.M. Bonke, \\ volgens het besluit van het College van Dekanen, \\ in het openbaar te verdedigen \\ op vrijdag 23 februari 1990 om 16.00 uur
}

door

HERBERT VAN DEN BERGE geboren te Maastricht op 12 oktober 1958 


\section{Promotores:}

Prof. Dr. E.H.M.A. Marres

Prof, Dr. J. Drukker

\section{Co-promotor:}

Dr. H. Kingma

\section{Beoordelingscommissie:}

Prof. Dr. J.W. Arends, Rijksuniversiteit Limburg (voorzitter)

Prof. Dr. P. van den Broek, Katholieke Universiteit Nijmegen

Prof. Dr. W.P.M.A. Lamers, Rijksuniversiteit Limburg

Prof. Dr. R.H. Rozendal, Universiteit van Amsterdam

Prof. Dr. F. Spaans, Rijksuniversiteit Limburg

\section{CIP-DATA KONINKLIJKE BIBLIOTHEEK, DEN HAAG}

Berge, Herbert van den

The middle ear muscles of the rat : morphological and functional aspects / Herbert van den Berge. - Mastricht : Datawyse. - III.

Thesis Maastricht. - With ref. - With summary in Dutch. ISBN $90-5291-017-0$ siso 598.95 UDC $611.85: 599.32(043.3)$

Subject headings: middle ear muscles ; rats / sound transmission / musculus tensor tympani.

Produktie en layout: Datawyse Maastricht, Ruud Leliveld Omslagontwerp: Hans Rensema Druk: Krips Repro Meppel 
Voor Mieke en Minke

Voor mijn ouders 
Deze studie werd mede financieel mogelijk gemaakt door de Stichting het Heinsius-Houbolt fonds.

Het verschijnen van dit proefschrift werd mede mogelijk gemaakt door financiële steun van: Stichting bevordering wetenschappelijk onderzoek KNO-heelkunde Maastricht, het Scholten-Cordes Fonds, Sarva-Syntex Nederland, Entermed B.V., Abbott B.V., Astra Pharmaceutica B.V., DG Lederle Nederland B.V., Veenhuis Medical Audio, Glaxo B.V., Oticon Nederland B.V.

De kleuren illustraties werden financieel mogelijk gemaakt door Duphar Nederland B.V. 


\section{Table of contents}

\section{CHAPTER 1}

\section{Introduction}

1.1 General introduction ............. 11

1.2 Historical review . . . . . . . . . . . 12

1.3 Aim of the study ............. 15

1.4 Contents of the study . . . . . . . . . . 16

1.5 References .............. 17

\section{CHAPTER 2}

Three dimensional reconstruction of the tympanic bulla of the rat with special reference to the middle ear muscles

Summary ................ . 21

2.1 Introduction . . . . . . . . . . 22

2.2 Materials and methods . . . . . . . . . 22

2.2.1 Preparation . . . . . . . . . . . . . 22

2.2.2 Plotting and drawing methods . . . . . . . 23

2.3 Results . . . . . . . . . . . . . . 24

2.4 Discussion .................. 33

2.5 References ................... 35

\section{CHAPTER 3}

Detailed morphology of the tensor tympani muscle of the rat An integrated light microscopical, morphometrical, histochemical, immunohistochemical and electron microscopical study in relation to function

Summary ................. . . 37

3.1 Introduction ................. 38

3.2 Materials and methods . . . . . . . . . 39

3.3 Results .................. . . 40

3.3 .1 Gross anatomy .............. 40 
3.3.2 Microscopic anatomy . . . . . . . . . . 40

3.3.3 Morphometry ... . . . . . . . . . . . 44

3.3.4 Enzyme histochemical characterization ..... 44

3.3.5 Immunohistochemistry . . . . . . . . . 47

3.3 .6 Electron microscopy $\ldots \ldots . . . . .47$

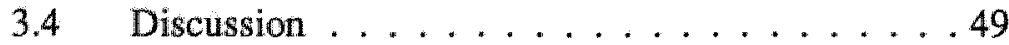

3.5 References ................ . . 54

\section{CHAPTER 4}

Detailed morphology of the stapedius muscle of the rat An integrated light microscopical, morphometrical, histochemical, immunohistochemical and electron microscopical study in relation to function

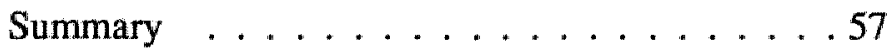

4.1 Introduction ................... . . . . . .

4.2 Materials and methods . . . . . . . . . . . 59

4.3 Results . . . . . . . . . . . . . . . 61

4.3.1 Gross anatomy . . . . . . . . . . . 61

4.3.2 Microscopic anatomy . . . . . . . . . . 661 6

4.3 .3 Morphometry ... . . . . . . . . . . 63

4.3.4 Enzymehistochemistry . . . . . . . . . . 64

4.3.5 Immunohistochemistry . . . . . . . . . . . 67

4.3.6 Electron microscopy . . . . . . . . . . . 69

4.4 Discussion ...................... 71

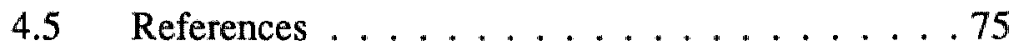

\section{CHAPTER 5}

The innervation of the middle ear muscles of the rat

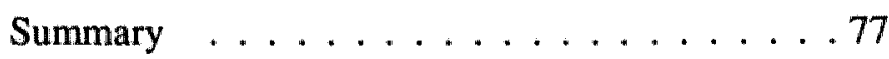

5.1 Introduction . . . . . . . . . . 78

5.2 Materials and methods . . . . . . . . . .79

5.3 Results . . . . . . . . . . . . . . . . .80

5.3.1 Gross innervation . . . . . . . . . . . 80

5.3 .2 Nerve fibre morphometry . . . . . . . . . . . . . . 83

5.3 .3 Motor innervation . . . . . . . . . . . . . 84 
5.3 .4 Sensory innervation .......... . . 87

5.4 Discussion ............... . . 90

5.5 References ................... 93

\section{CHAPTER 6}

Electrophysiological aspects of the middle ear muscle reflex in the rat

Latency, rise time and effect on sound transmission Summary .................. . . 95

6.1 Introduction . . . . . . . . . . . 96

6.2 Materials and methods ... . . . . . . . . 997

6.3 Results .................. 101

6.4 Discussion ............... 111

6.5 References .............. 115

\section{CHAPTER 7}

General discussion and conclusions $\ldots \ldots \ldots \ldots$

\section{CHAPTER 8}

Summary . . . . . . . . . . . . . 125

Samenvatting . . . . . . . . . . . 129

Nawoord .................... 133

Curriculum vitae $\ldots \ldots \ldots \ldots$ 



\section{CHAPTER 1}

\section{Introduction}

\subsection{General introduction}

Hearing is an elementary sensory function. It can warn us about dangers, it helps us in our orientation to the environment, and last but not least, it has an important function in communication. At the basis of this is a very complex hearing organ. Sounds pass through the outer ear, middle ear and inner ear, and are finally converted into electrical signals, which reach the brain, where perception takes place. The perception of sounds can be influenced by many factors, such as raising and twisting of the outer ears in an animal, or turning towards the source of the sound, but also by factors such as alertness and concentration, background noise, etc. In addition, the transmission of sounds over the ossicular chain can be influenced by the middle ear muscle reflex in mammals and many lower animals. In mammals, two small muscles are contained within the middle ear: the tensor tympani muscle and the stapedius muscle. They can be activated by various stimuli, such as sufficiently loud acoustic stimuli, self-phonation, swallowing, startle reactions and certain tactile stimuli (Djupesland, 1975). On contraction of these muscles, the biomechanical system of the middle ear is influenced, resulting in an attenuation, or sonetimes even an amplification of sound transmission over the ossicular chain. The function of these muscles in sound perception has been the subject of research for more than four centuries. Many speculations on their function have been made, and are still being made as research goes on. To elucidate the present hypotheses a short historical review may be helpful. 


\subsection{Historical review}

A general historical review was presented recently by Borg, Counter \& Rossler (1984) and much of the data presented here (vide infra) are derived from their work.

In the 16th century Bartholomeus Eustachius, and a few years later Constantius Varolius, first described respectively the tensor tympani and the stapedius muscle. Later on, some authors described up to six middle ear muscles. Apparently, they regarded the ligaments as muscles too. In this era the research was entirely morphological. Nevertheless speculations on the function of the middle ear muscles were already being made: Bartholomeus Eustachius proposed the idea that muscles are attached to the bones of a joint, and that therefore the ossicular chain is supplied with muscles too. The first speculation on a possible protective function of the muscles was made by Fabricius ab Aquapendente (1600). He suggested that the middle ear muscles serve a function in protecting the eardrum from damage caused by loud sounds. In the 17th century several authors started to relate contraction of the muscles with the conduction of sounds through the ossicular chain. Du Verney $( \pm 1683)$ suggested that the muscles accommodate the drum and the stapes footplate to sounds, analogous to accommodation of the eye. Later on, the muscles were thought to protect the ear from loud noises and to have a adaptive function in the receiving of faint sounds (Baptistae Morgagni, 1764). In the 19th century an intensivation of the research took place due to improved instrumentation and technology. Many experiments on various animals were performed, resulting in new and interesting findings. It was Politzer who initiated many of these experiments. For example, by stimulating the trigeminal and facial nerves in dogs, he showed that the tensor tympani muscle is innervated by the former and the stapedius muscle by the latter. It was Hensen (1878) who was the first to demonstrate the acoustic reflex. He observed that on stimulation with loud sounds the stapedial and tensor tympani muscles in dogs contracted reflexively. Up to the 1900 s the tensor tympani muscle was thought to fulfil the most important function. But in the basic animal experiments on cats and rabbits by Kato (1913) it became clear that the stapedius muscle contracted at a relatively lower sound level than the tensor tympani muscle. Kato also suggested that the muscles must be viewed as 
synergists, whereas previously they had been thought to act as antagonists.

Over the last forty years research on the middle ear muscles; both electrophysiologically and morphologically, intensified. This was mainly stimulated by the work of Metz (1946), who described the use of acoustic impedance measurements as a diagnostic tool in normal and pathological ears. It became apparent that with this non-invasive technique, the middle ear muscle activity could be shown and examined. During the last twenty years the development of the technique resulted in a worldwide routine use of acoustic impedance measurements as well as measurements of the stapedius reflexes as a diagnostic tool in hearing loss. The possibility of examining middle ear muscle activity, and the importance of the middle ear muscle reflex in the assessment and diagnosis of hearing loss stimulated basic research on the function of the middle ear muscles. It was now possible to measure in a non-invasive way parameters such as reflex thresholds, latency time and decay of the acoustic reflex. In man these studies mainly focussed on two aspects of the function of the middle ear muscle reflex: prevention of noise damage and improvement of speech perception. As regards the protection against noise damage, several studies have shown the protective effect of the reflex (Fletcher, 1960; Hilding, 1961; Sokolovski, 1973; Zakrisson, 1975; Brask, 1977; Zakrisson, 1979, Zakrisson, Borg, Lidén \& Nilsson, 1980). It was shown in several species that as a result of the middle ear muscle contraction, mainly the lower tones, i.e. below $2000 \mathrm{~Hz}$, are attenuated (Wever \& Bray, 1942; Borg, 1968, Cancura, 1970; Teig, 1973). The maximal attenuation was shown to be about $25 \mathrm{~dB}$ (Teig, 1972; Teig, 1973). In man, attenuation is also limited to frequencies below $2000 \mathrm{~Hz}$ (Pichler \& Bornschein, 1957). The maximal attenuation appeared to be about 20-30 dB (Borg, 1968; Brask, 1977; Zakrisson, 1979). However, these data were mainly derived from indirect measurements in open loop system during and after recovery of stapedius muscle paralysis (Bells palsy). The data suggest an important role of the reflex in the protection against noise damage. Of course it makes a lot of difference whether $110 \mathrm{dBnHL}$ or $85 \mathrm{dBnHL}$ reaches the inner ear. However, several objections can be made against the noise protection theory. First of all, only the very low frequencies as $250 \mathrm{~Hz}$ are attenuated that much. Around $2000 \mathrm{~Hz}$ attenuation is nihil, or a slight amplification occurs. Consequently there is no protection against higher pitch 
sounds. Secondly, the latency of the refier is considered to be too long to protect effectively against impulsive noise (Fletcher, 1960). The loud sound will have reached the inner ear before the mascles contract. Finally, 難 has been shown that after period of noise exposure a process of fatigue might occur, resulting in no protection at all. This phenomenon seems to occur especially during continous narrow band exposure (Thetze, 1969; Ferraro, Melnick \& Gerhardt, 1981). The reflex can, however, be reactivated when pitch or intensity is altered, as is the fact, for example, in most industrial noise. (See for references: Borg \& Nilsson, 1984).

The other important function attributed to the the middle ear muscle relex is the improvement of the perception of speech during vocalisation and in noise (Lidén, Nordlund \& Hawkins, 1964; Borg \& Zakrisson, $1975 a-b)$. The dynamic range of the inner ear has been shown to increase by $20 \mathrm{~dB}$ by the middle ear muscle reflex (Borg \& Zakrisson, $1973,1974,19756$ ). This is caused by attenuation of the lower tones wich would otherwise mask higher frequencies, which are especially important for the perception of speech. In addition, it has been shown that the reflex is often activated just prior to vocalisation (Salomon \& Star, 1963; Borg \& Zakrisson, 1975a). This might reduce low frequencies caused by the person's own voice and thereby improve the intelligability for external speech (Borg \& Zakrisson, 1975a-b).

From the recent literature it becomes apparent that major interspecies differences exist in both structure and function of the middle ear muscles. Most studies have concentrated on a certain aspect of morphology or electrophysiology in different species, and therefore no integration of these various aspects in one animal species was made. This is important since the function of the middle ear muscle reflex seems to be adapted to the special needs of a certain species. For example in the bat (Pteronotus parnelii), who's best frequency for hearing is $60.6 \mathrm{kHz}_{\text {; }}$ frequencies below $60.6 \mathrm{Khz}$ are being attenuated during vocalization (Pollak \& Henson, 1973), thereby possibly attenuating the amount of acoustic self stimulation during vocalization. The same is true for the perception of speech in man. In general the function of the reflex is described by Borg et al. (1984), who summarizes the function of the middle ear muscle reflex as prevention of desensitivation, interference and injury. 


\subsection{Aim of the study}

Still many questions related to the function of the muscles are left open such as: How do the middle ear muscles exert their function in the biomechanical system of the middle ear? What is the effect of contraction of the muscles on sound transmission? Are the muscles able to exert their function fast? Are the muscles able to exert their function for longer periods of time?

To get clues to the answers of these questions one would like to have a good three dimensional insight of the middle ear and the middle ear muscles-ossicular chain complex. In this way, more information about the biomechanical system of the middle ear could be obtained. Furthermore, one would like to know the morphological and biochemical characteristics of the muscle fibres. Are they able to contract fast? What type of myosin filaments do they consist of? Are they fatigue resistent? All are important questions to further analize the protective role of the reflex. One should also have more knowledge about the innervation of the muscles to get clues to the regulation of contraction of the muscles. How is the motor and sensory innervation organized? Can the muscles themselves participate in a feedback system with the cochlea? Therefore, a good insight in the innervation of the muscles is required.

The electrophysiological studies on the latency and rise time of the reflex have mostly been done by relatively indirect methods like for example impedance measurements. To obtain more precise data, more direct methods of measurement like electrocochleography and electromyography would be required.

Another question to be answered is: What is the contribution of the two muscles separately? In man only the stapedius muscle is believed to be active in the acoustic reflex, while the tensor tympani muscle would only be part of a more generalized startle reaction. Others suggest a function in the Eustachian tube opening (Ingelstedt \& Johnson 1967; Borg, 1973), or even no relevant function in hearing at all (Howell, 1984). In many animal species, however, both muscles have shown to be active in the acoustic reflex.

The aim of the study is to get clues to the answers of the morphological and electrophysiological questions above, in order to obtain an integrated insight in structure and function in one animal species. For this, one would need fresh middle ear muscles and one would need to do 
invasive electrophysiological studies. This impedes research in man. As previous morphologicall studies indicated that the middle ear muscles of the rat fairly resembled the human middle ear muscles, (Kobayashi, 1956a-b) we chose the rat as an animal model.

\subsection{Contents of the study}

This study is composed of five papers (Chapter 2 through 6 ) which are closely related to each other. Four of the papers concern anatomical studies. The fifth one presents the results of the electrophysiological study. It should be noted that the five studies are not presented in chronological order. Especially the three dimensional reconstruction (Chapter 2) has resulted in an even more realistic presentation of the topographical anatomy of the muscles than in Chapter 3 and 4.

First of all, to create an insight into the spatial relations in the tympanic bulla of the rat, computerized three dimensional reconstructions of the bulla are presented in Chapter 2. Special attention is given to the reconstruction of the ossicular chain-middle ear muscle complex, in order to get an insight into the biomechanics of the complex.

In Chapter 3 and 4 the detalled integrated morphology of the tensor tympani and stapedius muscle of the rat are presented. These Chapters intend to clarify the (sub)microscopical structure and histochemical characteristics of the muscle fibres. The functional implications are discussed.

In Chapter 5 the results of the study of the innervation of the muscles is presented. Various anatomical techniques are applied to shed light on the motor and sensory innervation of both muscles. The functional implications are discussed.

In Chapter 6 the effect on sound transmission, the effect of the eliciting stimulus on contraction of the muscles, the rise time and the latency of the reflex are studied. This is done in an experimental electrophysiological situation by means of methods such as electrocochleography and electromyography.

Chapter 7 tries to integrate and discuss the results of the studies presented. 


\subsection{References}

Borg, E. (1968). A quantitative study of the acoustic stapedius reflex on sound transmission through the middle ear of man. Acta Otolaryngologica 66,461 472.

Borg, E. (1973). Acoustic middle ear reflexes: A sensory-control system. Acta Otolaryngologica, Suppl. 304, 1-35.

Borg, E., Counter, S.A. \& Rösler, G. (1984). Theories about middle ear muscle function. In: The acoustic reflex; Basic principles and clinical applications (ed. S. Silman). Orlando, Florida: Academic Press.

Borg, E. \& Nilsson, R. (1984). Acoustic reflex in industrial noise. In: The acoustic reflex; Basic principles and clinical applications (ed. S. Silman). Orlando, Florida: Academic Press.

Borg, E., \& Zakrisson, J.-E. (1973). Stapedius reflex and speech features. The Journal of the Acoustical Society of America 54, 525-527.

Borg \& Zakrisson (1974). Stapedius reflex and monaural masking. Acta Otolaryngologica 78, 155-161.

Borg, E. \& Zakrisson, J.-E. (1975a). The activity of the stapedius muscle in man during vocalization. Acta Otolaryngologica 79, 325-333.

Borg, E. \& Zakrisson J.-E. (1975b). Stapedius muscle and speech perception. In: Sound perception in mammals. Symposia of the Zoological Society of London (Ed. R.J. Bench, A. Pye, \& J.D. Pye). No: 37, 51-68.

Brask, T. (1977). Extratympanic manometry in man. Scandiavian Audiology, Suppl. 7, 134-161.

Cancura, W. (1970). Der Einfluss der Binnenohrmuskulatur auf die Schallïbertragung im Mittelohr. Monatschrift für Ohrenheilkunde und Laryngolo-Rhinologie 19, 3-46.

Djupesland, G. (1975). Advanced reflex considerations. In: Handbook of Clinical Impedance Audiometry (ed. J.J. Jerger). Dobbs Ferry, New York: American Electromedics Cooperation, 85-125.

Du Verney, G.J. (1683) Traité de L'organe de L'ouie. Paris: Estienne Michalet.

Fabricius ab Aquapendente, Hieronymus. 1600. De visione, voce et auditu. Venice.

Ferraro, J.A., Melnick, W. \& Gerhardt, K.R. (1981). Effect of prolonged noise exposure in Chinchillas with severed middle ear muscles. American Journal of Otolaryngology 2, 13-18.

Fletcher, J.L. (1960). The protective effect of the acoustic reflex reflex for impulsive noise. Journal of Acoustic Society of America 32, 401-404. 
Fletcher, J.L. Riopelle, A.J. (1960). Protective effect of the acoustic reflex for impulsive noises. The Joumal of the Acoustical Society of America 32, 401404.

Hensen, $V .(1878)$. Beobachtungen uber die Thätigkeit des Trommelfell-spanners bei Hund und Katze. Archiv fur Anatomie und Physiologie, Physiologische Abtheilung $2,312-319$.

Hilling, D.A. (1961). The protective value of the stapedius reflex." An experimental study. Transactions-American Academy of Ophtalmology and Otolarygology $65,297-307$.

Howell, P. (1984). Are two muscles needed for the normal functioning of the mammalian middle ear? Acta Otolaryngologica 98, 204-207.

Ingelstedt, S. \& Johnson, G. (1967). Mechanisms of the gas exchange in the normal human middle ear middle ear. Acta Otolaryngologica, Suppl. 224, $452-461$.

Kobayashi, M. (1956a). Comparative anatomical studies of the morphology of the tensor tymani muscles of various mammals. Hirochima Journal of Medical Science 5, 85-108.

Kobayashi, M. (1956b). The comparative anatomical study of the stapedial muscles of the various kinds of mammalian animals. Hirochima Journal of Medical Science 5, 63-84.

Kato, T. (1913). Zur Physiology der Binnenmuskeln des Ohres. Plüger"s Archiv fur die gesamte Physiology des Menschen und der Tiere 150, 569-625.

Lidén, G., Nordlund, B. \& Hawkins jr, J.E. (1964). Significance of the stapedius reflex for the understanding of speech. Acta Otolaryngologica, Suppl. 188, 275-279.

Metz, O. (1946). The acoustic impedance measured on normal and pathological ears. Acta Otolaryngologica, Suppl. 63, 1-254.

Morgagni, J.B. (1764). Epistolae anatomicae. Patavii.

Pichler, H. \& Bornschein, H. (1957). Audiometrischer nachweis nichtakustisch ausgelóster Reflexcontraction der intrauuralen muskulatur. Acta Otolaryngologica, 48, 498-503.

Pollak, $\mathrm{G}_{\text {. \& Henson }}$ O. W. jr. (1973). Specialized functional aspects of middle ear muscles in bat, Vhilonycteris parnellii. Journal of Comparative Physiology $84,167-174$.

Salomon, G. \& Starr, A. (1963). Electromyography of the middle ear muscles during motor activities. Acta Neurologica Scandinavica 39, 161-168.

Sokolovski, A. (1973). The protective action of the stapedius muscle in noise-induced hearing loss in cats. Archiv für klinische und experimentelle Ohren-, Nasen- und Kehlkopfheilkunde 203, 289-309. 
Teig, E. (1972). Fonce and contraction velocity of the middle ear muscles in the cat and the rabbit. Acta Physiologica Scandinavica 84, 1-10.

Teig, E. (1973). Differential effect of graded contraction of middle ear muscles on the sound transmission of the ear. Acta Physiologica Scandinavica 88, 382391.

Tietze, G. (1969). Zum Zeitwerhalten des akustischen Reflexes bei Reizung mit Dauertönen. Archiv für klinische und experimentelle Ohren-, Nasen- und Kehlkopfheilkunde 193, 43-52.

Wever, E.G., \& Bray, C.W. (1942). The stapedius muscle in relation to sound conduction. Journal of Experimental Psychology 31, 35-43.

Zakrisson, J.-E. (1975). The role of the stapedius reflex in poststimulatory auditory fatigue. Acta Otolaryngologica 79, 1-10.

Zakrisson, J.-E. (1979). The effect of the stapedius reflex on attenuation and post-stimulatory auditory fatigue at different frequencies. Acta Otolaryngologica, Suppl. 360, 118-121.

Zakrisson, J.-E., Borg, E., Lidén, G. \& Nilsson, R. (1980). Stapedius reflex in industrial impact noise: Fatigability and role for temporary threshold shift (TTS). Scandinavian Audiology, Suppl. 12, 326-334. 


\section{Three dimensional reconstruction of the tympanic bulla of the rat with special reference to the middle ear muscles}

\section{Summary}

On the basis of functional questions, graphic three dimensional reconstructions of the tympanic bulla of the rat were made to gain insight into the spatial organisation of the content of the bulla and especially the tympanic membrane-ossicular chainmiddle ear muscles complex. For this purpose drawings of microscopical sections of complete bullae were fed into the computer to make three dimensional graphic reconstructions with hidden line removal. From these reconstructions plastic representations were made by the medical artist. The topographical anatomy of the tympanic bulla is discussed in detail and compared to the anatomy of the middle ear in man. On the basis of the topographical anatomy it is feasible that the muscles in the rat act synergistically in increasing the stiffness of the ossicular chain. It is postulated that despite differences in spatial organisation of the middle ear of the rat compared to that in man, the middle ear muscles influence the ossicular chain in a comparable way.

Berge, H. van den, Geest, A. van \& Rensema, H.

Submitted for publication. 


\subsection{Introduction}

The tensor tympani and stapedius muscles have been the subject of intensive study in the past. Many theories on the function of the muscles have been proposed and some of them rejected. There has been evidence of a role in protection against noise damage, in improvement of (speech) perception by selective attenuation of certain frequencies, and of a possible function in the attenuation of sounds during own vocalisation (Borg, Counter \& Rösler, 1984). In addition, the middle ear muscles have been thought just to have a function as a ligament, or even to be of no importance at all for normal hearing. From the studies in various animal species it became apparent that major interspecies differences exist in both structure and function of the muscles (For references see: Berge \& Wirtz (1989b) \& Borg, Counter \& Rösler (1984)). Therefore, we set out to perform an integrated anatomical and electrophysiological study in the rat. The detailed morphological characteristics of the muscle fibres of the tensor tympani and stapedius muscles and the innervation of the muscles have already been described (Berge \& Wirtz, 1989a; Berge \& Wirtz, 1989 b; Berge \& Wal, 1990). To obtain clues to what influence the middle ear muscles have on the biomechanical system of the middle ear and thereby to the influence on sound transmission, a good insight into the spatial organisation of the middle ear of the rat is necessary. Therefore, in this study we set out to create three dimensional reconstructions of the tympanic bulla of the rat with special reference to the middle ear muscles.

\subsection{Materials and methods}

\subsubsection{Preparation}

Two left tympanic bullae of two 12 weeks old male Lewis rats were studied. During Narcovet anaesthesia, perfusion fixation was carried out via the abdominal aorta with neutral formalin at $4^{\circ} \mathrm{C}$ (Lillie, 1954). The bullae were removed including a part of the occipital bone to spare the facial nerve, and trimmed of the tissues around them. Post fixation was done in neutral formalin for one night at $4^{\circ} \mathrm{C}$. For this purpose a 
small hole was made in the thin ventro-lateral wall of the bulla. After washing in running tap water, the bullae were dehydrated in a graded series of ethanol. The specimens were embedded in Technovit 7001 (methylmetacrylate). To promote impregnation, the uncatalysed plastic was introduced into the specimen via a graded series of mixtures with chloroform at $4^{\circ} \mathrm{C}$. These steps, up to $100 \%$ uncatalysed plastic, were carried out in a vacuum-exsiccator to promote impregnation of the mixture and evaporation of the gas components. The bullae were put in a mould on a bottom layer of already catalysed plastic and oriented for sectioning. Then the remainder of the catalysed plastic was poured into the mould. To avoid the development of too much heat and gas bubbles, the specimen was cooled. Finally, the plastic blocks were left to harden overnight at room temperature. The plastic blocks were trimmed at perpendicular angles. As reference marks, four parallel grooves were made perpendicular to the plane of sectioning on two sides of the blocks. Serial sections of $10 \mu \mathrm{m}$ were made with an LKB multirange microtome. The sections were collected on adhesive tape to prevent deformation and loss of tissue. Then floating sections were stained with a trichrome dye, Weigert/van Gieson (Romeis 1968, modified by Wal, 1988). Finally, the sections together with the adhesive tape were mounted on microscope slides with glycerin gelatin. (For a detailed description of the procedure see Lataster, Geest, Berge \& Drukker, 1990)

\subsubsection{Plotting and drawing methods}

The sections were projected with a Kindermann A.V. 100 slide projector with an adapted slide holder (magnification 18.5x) and line drawings were made by tracing the outlines of about 50 anatomical structures of the bulla to be reconstructed. The four grooves carved into the plastic block and the $90^{\circ}$ angles of the outline of the plastic block were used to produce reference points. In this way one drawing was made of every 5 sections, resulting in a distance of $50 \mu \mathrm{m}$ between each drawing. With a digitiser (Summagraphics ID series) 85 drawings (i.e. a total distance of about $4.3 \mathrm{~mm}$ ) and their reference points were fed into an MINC PDP $11 / 73$ computer. With the help of an especially designed drawing program (Beursgens, Mameren \& Drukker, 1987) three dimensional graphic reconstructions with "hidden line removal" 
of the bulla including the middle ear muscles could be made. These could be visualized on a Tektronix 4111 screen and a Tektronix 4696 hard copy unit. The computer program allowed for selecting individual structures to be reconstructed. By changing the point of view the structures were studied from different sides. (See for more details: Wal, 1988). From these data graphical refined plastic representations were made by the medical artist (H. Rensema).

In this paper the reconstructions of one of the tympanic bullae are presented. The other bulla, sectioned in a plane perpendicularly to the plane of the first bulla, was used as a reference.

\subsection{Results}

In Figure 2.1 (a-d) four hard copies of the computerized reconstructions are presented. The figure shows a part of the tympanic bulla (2.1a), the ossicular chain and middle ear muscles (2.1b), the tensor tympani muscle (2.1c), and the stapedius muscle (2.1d). The sections are shown mounted upon each other. Plastic representations of these reconstructions are presented respectively in Figure 2.3-2.6. For orientation, the planes of sections in Figure 2.3 are indicated in Figure 2.2. In Figure $2.3 \mathrm{a}$, a lateral view on the bulla is obtained. The outer ear canal, the tympanic membrane, the malleus, the facial nerve, and a part of the tympanic cavity can be seen. Figure $2.3 \mathrm{~b}$ presents a more medial view into the bulla, which presents an overview of the structures in the tympanic cavity. The ossicular chain, which is found in the dorsocaudal part, occupies only a relatively small part of the tympanic cavity. The ossicles are connected to the bony wall of the bulla by multiple ligaments. In this way also the head of the stapes is connected to the bony bulla wall by a ligament lateral to the tendon of the stapedius muscle.

The cranial part of the tympanic cavity is relatively large and empty. There the tensor tympani muscle is found in the medial wall of the

Fig. 2.1 (a-b). Computerized three dimensional graphic reconstructions of the tympanic bulla of the rat. (a) Reconstruction of a part of the tympanic bulla. Ventro-lateral view. (b) Reconstruction of the pars tensa of the tympanic membrane, ossicular chain and middle ear muscles. Ventral view. 


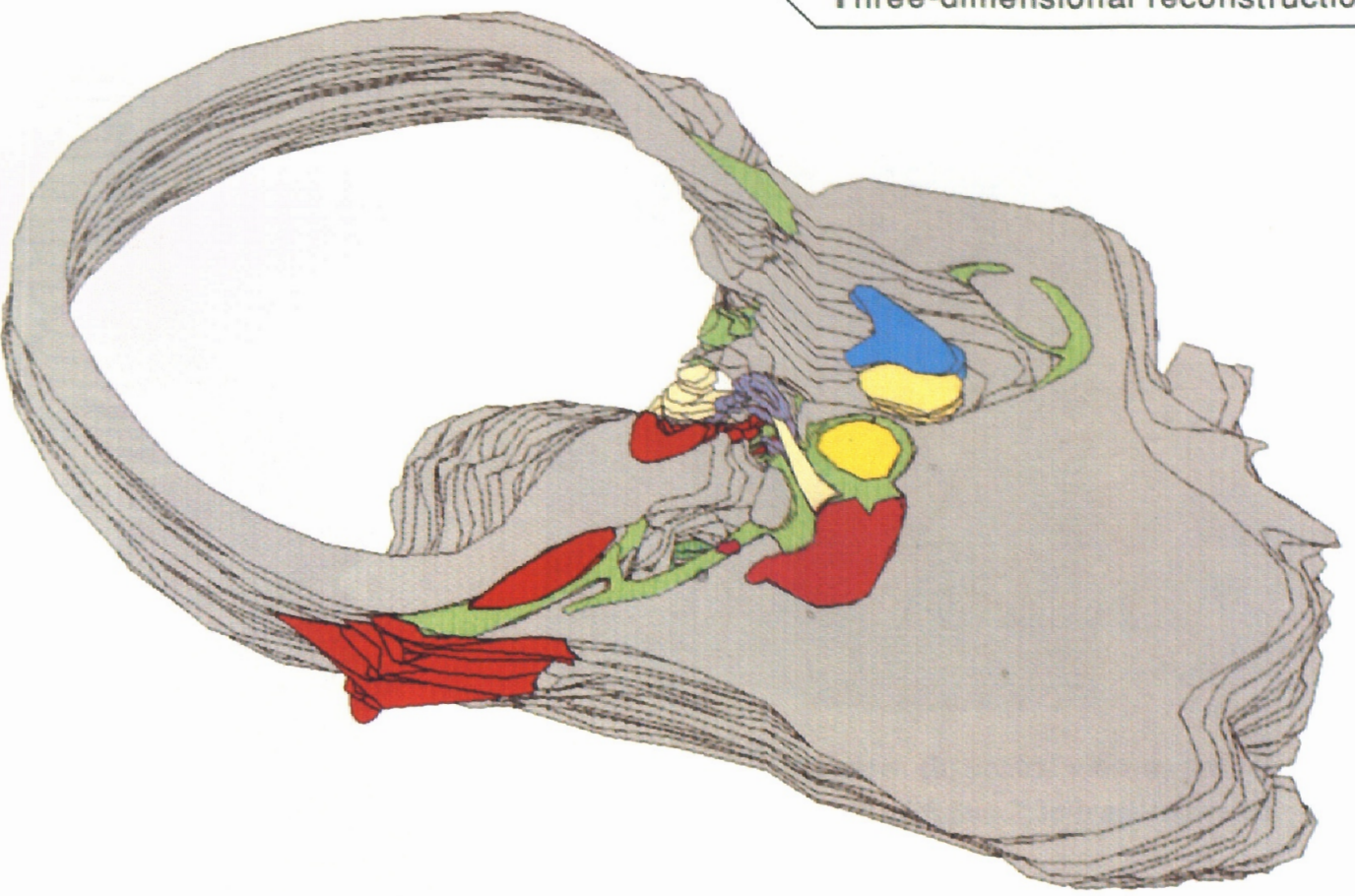

a

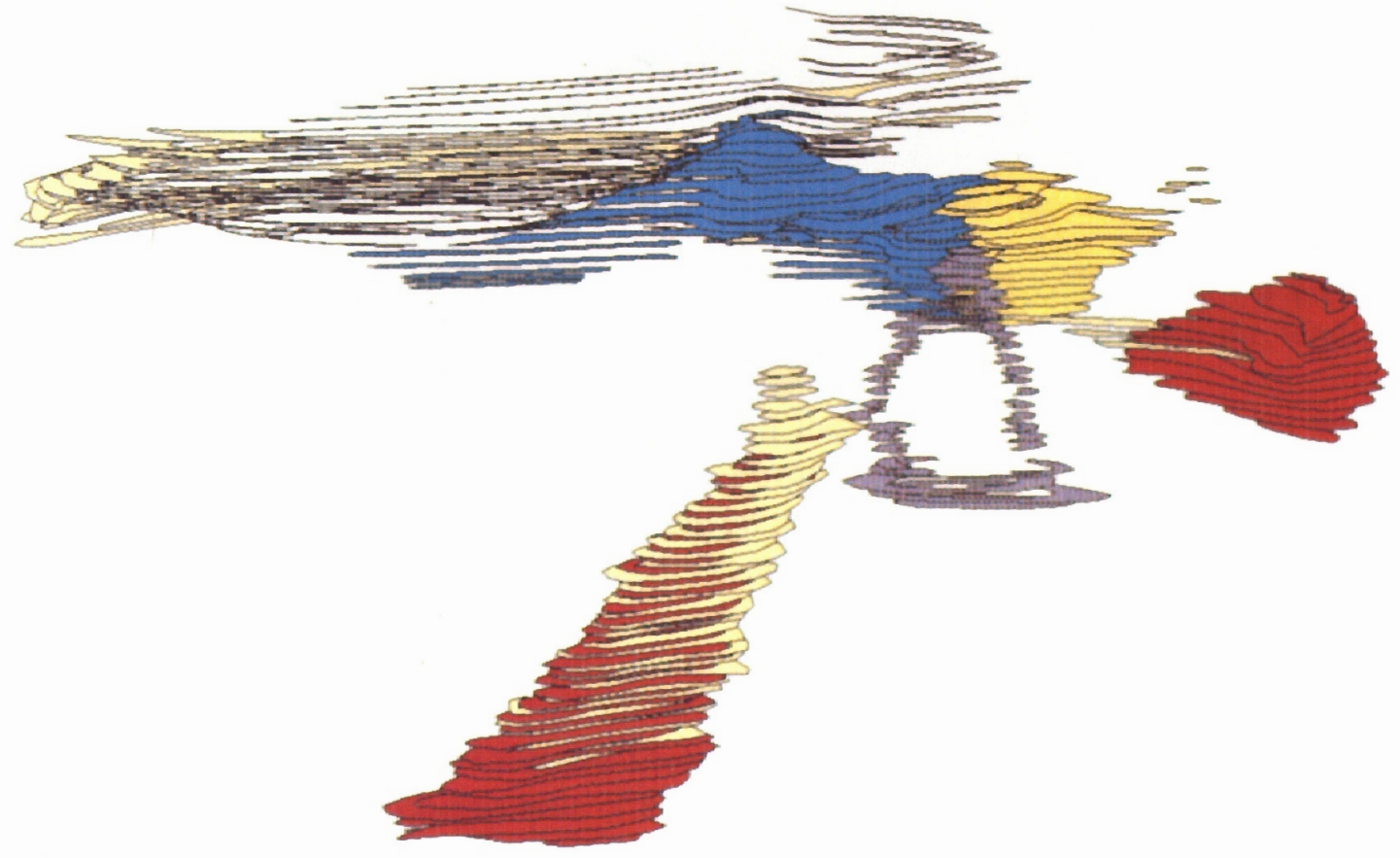

b 
Chapter 2

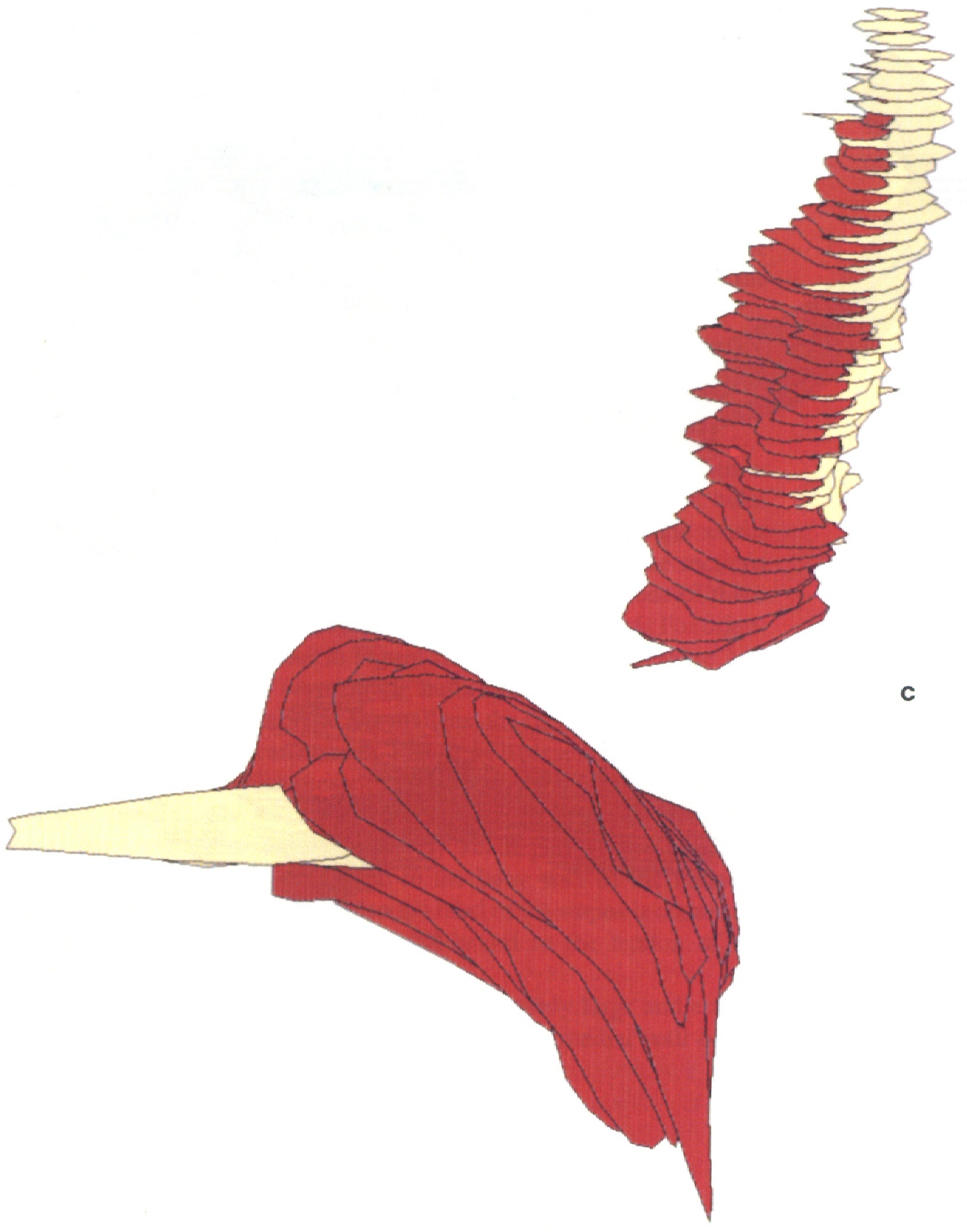

d 


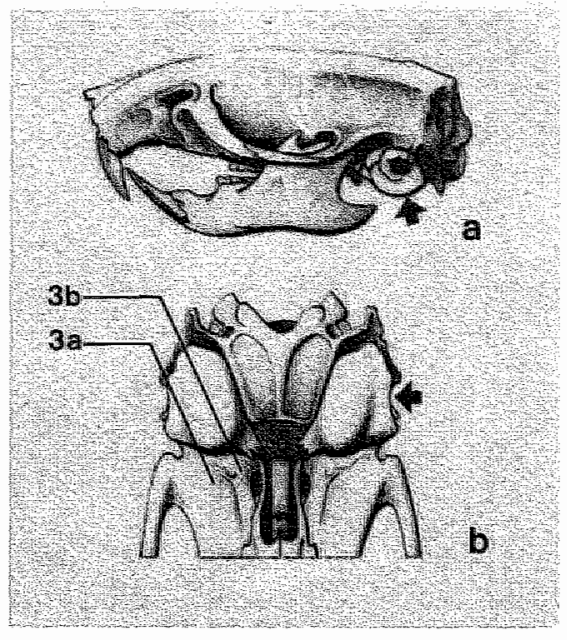

Fig. 2.2 (a,b). Skull of the rat. (a), Lateral view. (b) ventral view on the caudal part of the base of the skull. The planes of section of figure 2.3a-b are indicated.

Arrow: tympanic bulla.

bulla. The muscle is situated for a small part in a bony canal at the site of the tympanic orifice of the Eustachian tube. This canal develops into a bony semi-canal to the site of insertion resulting in an exposure of the lateral aspect of the muscle into the tympanic cavity.

In the caudo-ventral part of the bulla the round window niche and the stapedial artery, which passes between the crura of the stapes, are found. Caudally to the round window niche the stapedius muscle is situated within the bony wall of the bulla. The connective tissue covering the muscle presents itself in the tympanic cavity via a very narrow longitudinal slit in the bone, through which also the tendon leaves the bony cavity which contains the muscle.

It should be noted that not all the connective tissue elements were reconstructed, resulting in for example a space around the facial nerve. In Figure 2.4a ventral view on the isolated ossicular chain and middle ear muscles is presented. From this figure and Figure $2.3 \mathrm{~b}$ the spatial

$<$ Fig. 2.1 (c-d) Continued. Computerized three dimensional graphic reconstructions of the tympanic bulla of the rat. (c) Tensor tympani muscle. Cranial view. (d) Stapedius muscle. Lateral view. 


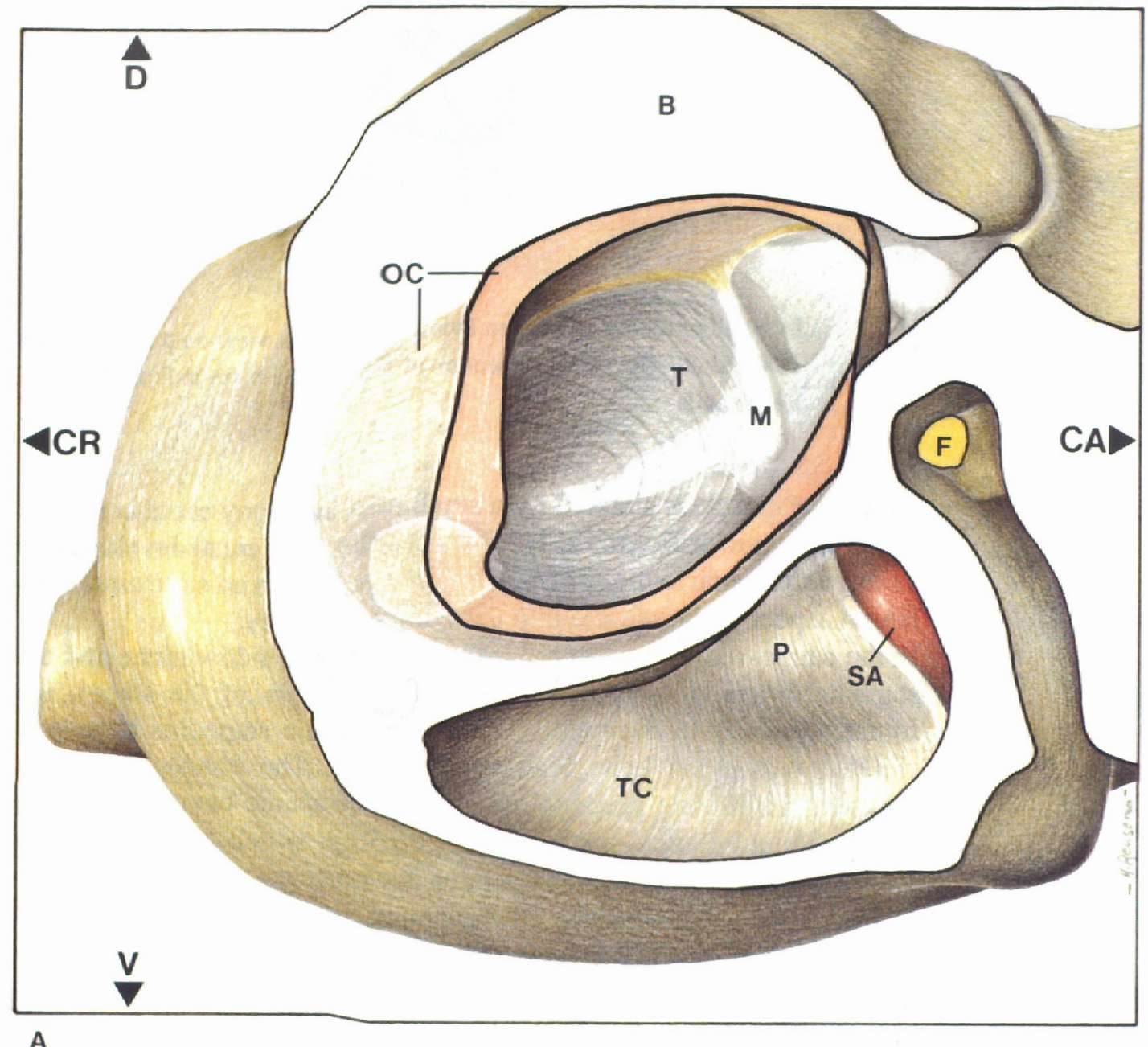




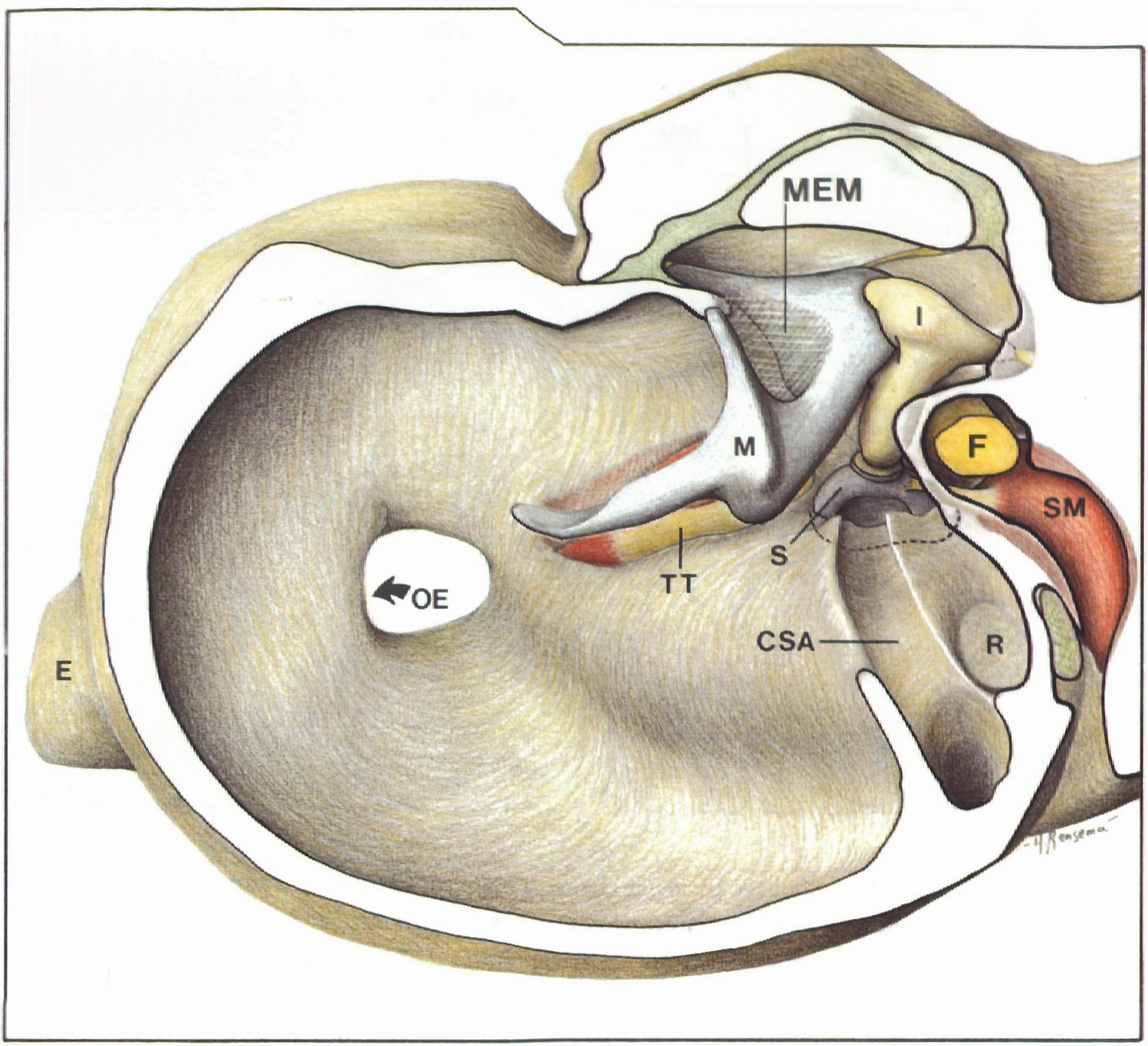

\section{A}

4 Fig. 2.3 (a-b). Plastic representation of a left tympanic bulla of the rat. (a,b) Lateral views into the bulla. The plane of section in (a) and (b) are indicated in figure $2.2 \mathrm{~b}$. $\mathrm{B}$, bony wall of tympanic bullia; CA, caudal side; CR, cranial side; CSA, canal of stapedial artery; D, dorsal side; E, Eustachian tube; F, facial nerve; M, malleus; MEM, membrane between anterior and cranial process of malleus; OC, outer ear canal; OE, tympanic orifice of Eustachian tube; $\mathrm{P}$, promontory; $\mathrm{R}$, round window niche; S, stapes; SA, stapediall artery; SM, stapedius muscle; T, tympanic membrane; TC, tympanic cavity; TT, tensor tympani muscle; V, ventral side. Nota bene: the chorda tympani and various connective tissue elements are not shown. 


\section{Chapter 2}

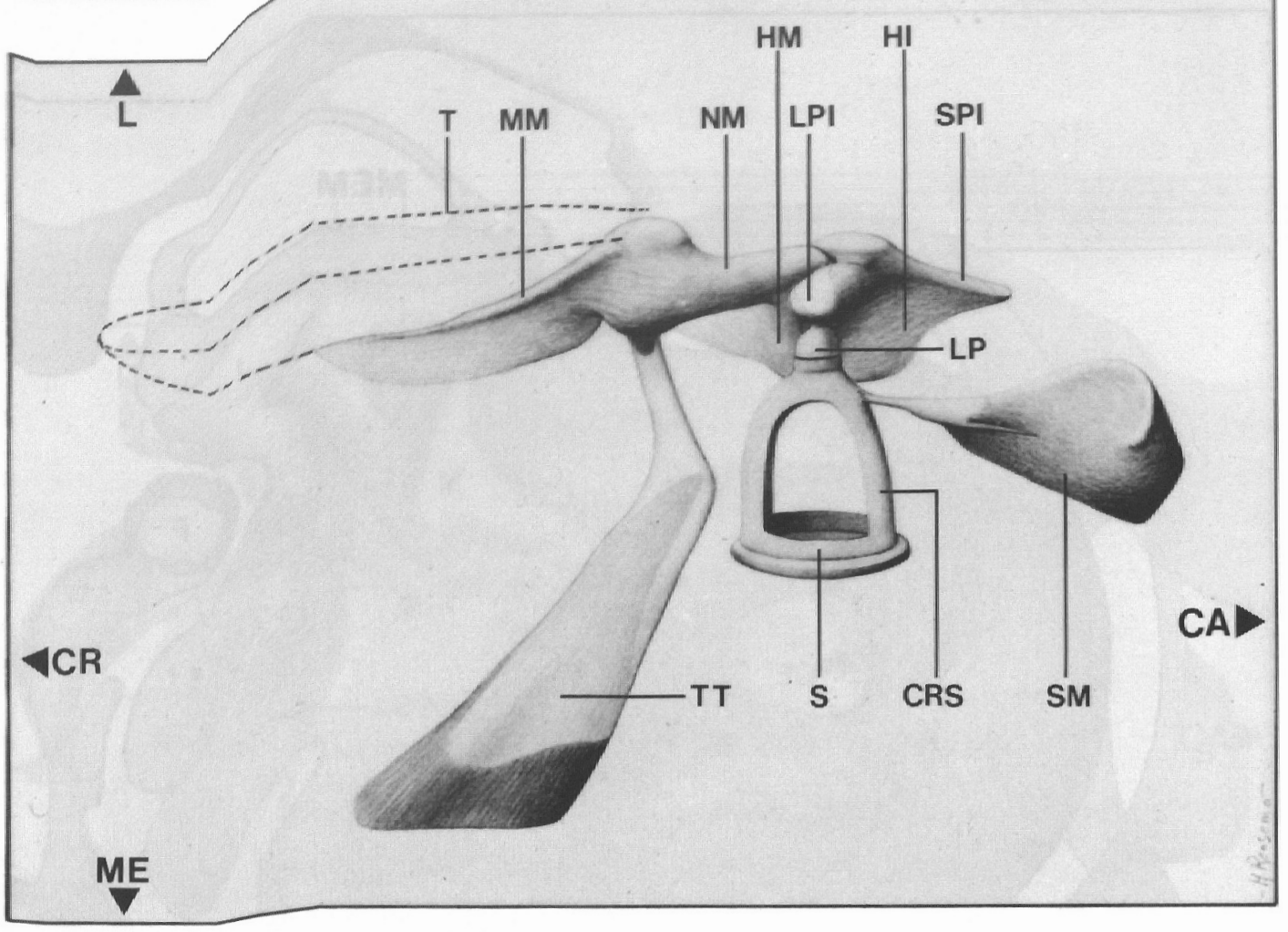

Fig. 2.4. Plastic representation of the ossicular chain, middle ear muscles and pars tensa of the tympanic membrane of the rat. Ventral view. CA, caudal side; CR, cranial side; CRS, caudal crus of stapes; HM, head of malleus; HI, head of incus; $L$, lateral side; LP, lenticular process of incus; LPI, long process of incus; ME, medial side; MM, manubrium of malleus; NM, neck of malleus; S, stapes; SM, stapedius muscle; SPI, short process of incus; T, pars tensa of tympanic membrane; TT, tensor tympani muscle.

configuration of the ossicular chain and middle ear muscle complex can be studied. As regards the ossicles, the neck of the malleus is relatively long, there is a cranial process (processus cephalicus) of the head of the malleus and a membrane between the dorsal process of the manubrium of the malleus (processus folianus) and the cranial process of the caput of the malleus. The malleo-incudal joint is saddle shaped. The lenticular proces of the incus is connected to the long process by 


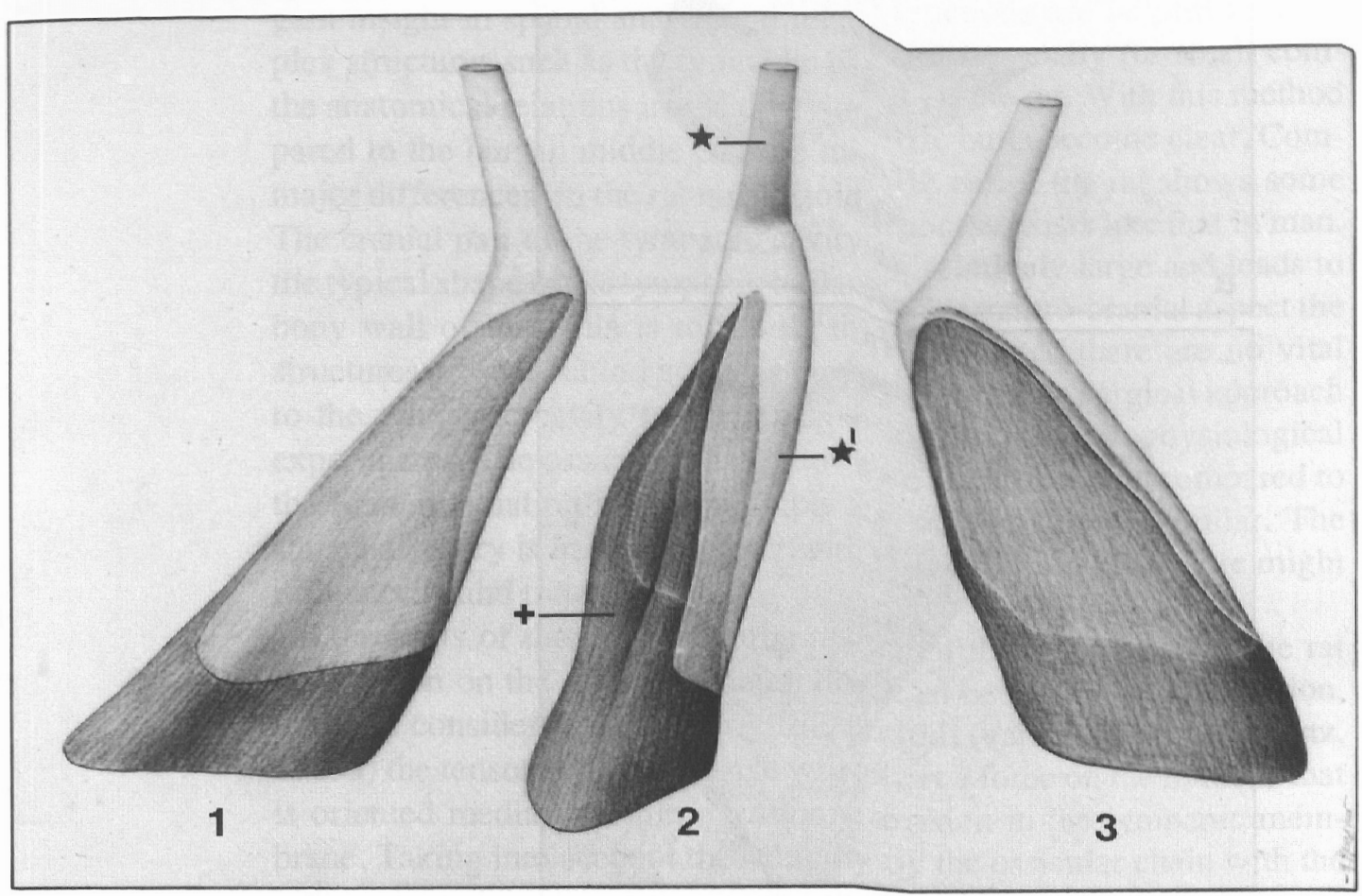

Fig. 2.5. Plastic representation of the tensor tympani muscle of the rat.

(1) Ventral view. (2) Cranial view. (3) Dorsal view.

$\star$, tendon; $\star^{1}$, tendon plate; + , muscular part.

a very thin osseous band, almost resulting in an fourth ossicle. The articular surfaces in the incudo-stapedial joint are flat. The stapes is situated in the deep fossa of the oval window niche. As regards the middle ear muscles, the tensor tympani muscle is attached to the medial process of the malleus. The tendon is relatively large and forms a large plate that partly envelopes the muscular part at the ventral site (Fig. 2.5). The stapedius muscle is attached to the caudal crus of the stapes by a very small tendon. The tendon leaves the muscle from its cranial aspect. The configuration of the muscle is presented in detail in Figure 2.6. 


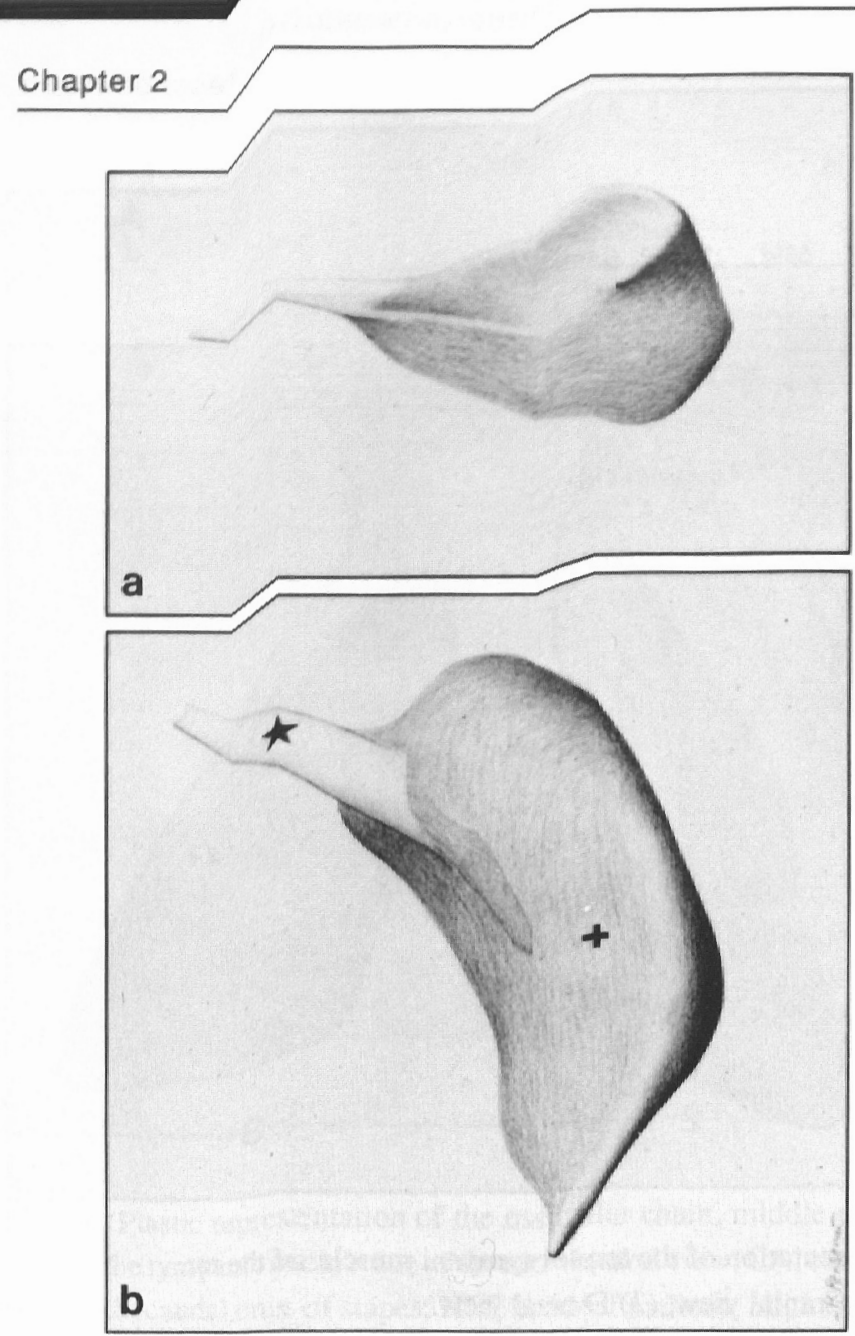

Fig. 2.6 (a,b). Plastic representation of the stapedius muscle of the rat. (a) Ventral view. (b) Lateral view. $\star$, tendon; +, muscular part. 


\subsection{Discussion}

Computerized three dimensional reconstructions are helpful tools to gain insight in spatial anatomical relations, especially for small complex structures such as the tympanic bulla of the rat. With this method the anatomical relations inside the tympanic bulla become clear. Compared to the human middle ear, the middle ear of the rat shows some major differences. In the rat no mastoid process exists like that in man. The cranial part of the tympanic cavity is relatively large and leads to the typical shape of the tympanic bulla. At the ventro-cranial aspect the bony wall of the bulla is relatively thin and since there are no vital structures present behind it, this is the ideal site for a surgical approach to the tympanic cavity for example to perform electrophysiological experiments. The ossicular chain shows some differences compared to the human situation but in principle its construction is similar. The stapedial artery is in close contact with the stapes and therefore might influence sound transmission.

On the basis of the spatial configuration of the middle ear of the rat speculation on the effect of contraction can be made. On contraction, which is considered to be nearly isometrical (van den Berge \& Wirtz, 1989a) the tensor tympani muscle will exert a force on the malleus that is oriented medially resulting in more tension in the tympanic membrane. Taking into account the anatomy of the ossicular chain with the saddle shaped malleo-incudal joint, this could result in an increase of stiffness in the incudo-stapedial joint. On contraction of the stapedius muscle the stapes will be tilted in caudal direction and its mobility in the oval window niche will be limited. In addition, a small translation in the incudo-stapedial joint and possibly compression in the malleoincudal joint might occur, also resulting in an increased stiffness of the ossicular chain. However, to verify this hypothesis, a dynamical three dimensional model of the middle ear of the rat would be desired to study the biomechanical changes in the ossicular chain caused by contraction of the muscles.

In conclusion, it seems likely that both middle ear muscles act synergistically in increasing the stiffness of the ossicular chain, as has been found in man (Møller, 1964). Despite the differences in architecture of the middle ear of the rat and the middle ear in man, the 
biomechanical organisation of the ossicular chain and the middle ear muscles seems to be similar in principle, which justifies comparative studies in this field.

\section{Acknowledgements}

We thank drs. L.M.A. Lataster for his valuable advices concerning the histological technique and ing. J.P.W.M. Beursgens for his management of computerized reconstruction. We thank Prof. dr. J. Drukker and Dr. H. van Mameren, from the department of Anatomy and Embryology, University of Limburg, for their constructive comments on the manuscript.

This study was supported by the Heinsius-Houbolt Foundation. 


\subsection{References}

Berge H. van den \& Wirtz P. (1989a) Detailed morphology of the tensor tympani muscle of the rat. An integrated light microscopical, morphometrical, histochemical, immunohistochemical and electron microscopical study in relation to function. Journal of Anatomy 164, 215-228.

Berge, H. van den \& Wirtz P. (1989b). Detailed morphology of the stapedius muscle of the rat. An integrated light microscopical, morphometrical, histochemical, immunohistochemical and electron microscopical study in relation to function. Journal of Anatomy 166, 157-169.

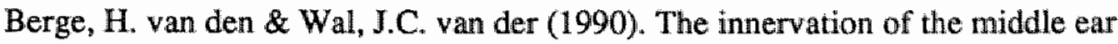
muscles of the rat. Journal of Anatomy (in press).

Beursgens J.P.W.M., Mameren, H. van \& Drukker, J. (1987). A computer-aided reconstruction technique in anatomical research and teaching. Acta Anatomica $130,11$.

Borg, E., Counter, S.A. \& Rösler, G. (1984). Theories about middle ear muscle function. In: The acoustic reflex; Basic principles and clinical applications (ed. S. Silman). Orlando, Florida: Academic Press, 63-100.

Lataster, L.M.A., Geest, A. van, Berge, H. van den \& Drukker, J. (1990). Histological preparation of non-decalcified bone and soft tissue for mesoscopic observations. Submitted for publication.

Lillie, R.D. (1954). Histopathologic technic and practical histochemistry. The Blakiston Company: New York, Toronto.

Møller, A.R. (1964). Effect of tympanic muscle activity on movement of the eardrum, acoustic impedance and cochlear microphonics. Acta. Otolaryngologica $58,525-534$.

Romeis, B. (1968). Microscopische Technik, 16th edition, R. Oldenburg Verlag, München-Wien, 174.

Wal, J.C. van der. (1988). The organization of the substrate of proprioception in the elbow region of the rat. Thesis. University of Limburg, Maastricht, The Netherlands. 


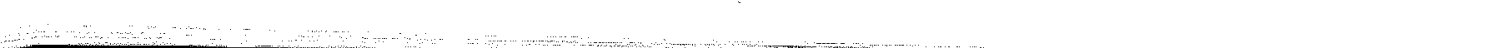




\title{
CHAPTER 3
}

\section{Detailed morphology of the tensor tympani muscle of the rat}

\author{
An integrated light microscopical, morphometrical, \\ histochemical, immunohistochemical and electron \\ microscopical study in relation to function
}

\section{Summary}

The gross anatomy, microscopical anatomy, morphometry, enzyme histochemistry, immunohistochemistry and electron microscopy of the tensor tympani muscle of the rat were studied. The aim of the study was to create an integrated insight in the morphology of the muscle and to discuss functional implications.

The tensor tympani muscle of the rat showed to be an atypical muscle. It is a small muscle composed of very small muscle fibres with a complex microscopical and submicroscopical architecture. Histochemically the muscle consists of mainly fast oxidative glycolytic fibres, but discrepancies are found when anti-heavy chain myosin antibodies are used for fibre typing. Different adult heavy chain myosins isotypes coexist in one single muscle fibre. The electron microscopical study shows that bundles of myofilaments branch and interconnect with other bundels of myofilaments.

The findings suggest that the muscle is able to contract fast and is fatigue resistant. Both features seem to suggest that the muscle can have a function in protecting the inner ear against noise damage.

Berge, H. van den \& Wirtz, P. (1989).

Journal of Anatomy 164, 215-228. 


\subsection{Introduction}

Despite extensive research throughout centuries the precise function of the smallest striated muscles in mammals, the stapedius muscle and the tensor tympani muscle, remains rather obscure. Several speculations about their function have been proposed (See for references: Guthrie, 1940; Borg, Counter \& Rösler, 1984). One of the most attractive theories on the function attributed to the middle ear muscles is that they protect the inner ear from noise damage. This theory, however, has become contested on the basis of assumptions that (i) contraction, especially of the tensor tympani muscle, takes place too slowly to protect the ear from loud impact noise and that (ii) a process of fatiguability of the muscle reflex occurs over longer periods of noise exposure (Borg \& Nilsson, 1984).

Detailed integrated knowledge of the morphological, enzyme histochemical and immunohistochemical characteristics would be of help in shedding light on the properties of the fibres of the tensor tympani muscle and hence help to understand their role in sound transmission in the middle ear. Most anatomical studies so far, however, have been focussed on one, or at most only a few, of the characteristics mentioned above (Zuckerkandl, 1884; Krebs, 1905; Spiesman, 1927; Malan, 1934; Kobayashi, 1956; Malmfors \& Wersäll, 1960; Brzezinski, 1962; Blevins, 1963; David, Gerhardt \& Uerlings, 1966; Mascarello, Carpenè, Veggeti, Rowlerson \& Jenny, 1982; Gerhardt, David \& Marx, 1966; Fernand \& Hess, 1969; Hirayama, Davidowitz \& Daly, 1974; Anderson, 1975; Haugsten, Bendiksen, Dahl \& Teig, 1982; Veggetti, Mascarello \& Carpenè, 1982; Mascarello, Veggetti, Carpenè \& Rowlerson, 1983; Haugsten, Dahl \& Teig, 1984; Jong, Wirtz, Kingma, van den Berge \& Marres, 1988). In addition most reports have dealt with different animal species showing major interspecies differences (Kobayashi, 1956; Mascarello et al., 1982; Veggeti et al., 1982; Mascarello et al., 1983). As a result, the integrated knowledge of the exact characteristics of middle ear muscles in a single species is not at present, available. We therefore set out to study the gross anatomy, microscopic anatomy, muscle fibre morphometry, enzyme histochemistry and electron microscopy of the tensor tympani muscle in the rat, in an attempt to gain insight in its possible role in sound transmission. 


\subsection{Materials and methods}

After studying the topographical anatomy, ten tensor tympani muscles of twelve weeks old male Lewis-rats were removed during pentobarbitone anaesthesia. Immediately after removal the muscles were frozen in liquid nitrogen-cooled isopenthane. Serial cryosections of $10 \mu \mathrm{m}$ were made and the following staining techniques were applied: (a) Sirius red (Sweat, Puchtler \& Rosenthal, 1964, modified by Lubbers, Loermans \& Wirtz, 1988); (b) myofibrillar ATPase (ATPase, EC 3.6.1.3, Dubowitz \& Brooke, 1973; Padykula \& Herman, 1955) preincubation $\mathrm{pH} 3.9,4.1,4.35,6.4,9.3$ and 10.3 ; (c) succinicdehydrogenase (SDH, EC 1.3.99.1, Nachlas et al. 1957); (d) alpha glycerophosphate dehydrogenase (GPox EC 1.1.99.5, Wattenberg \& Leong, 1960 , modified for GPox by Meijer \& De Vries, 1978); (e) immunohistochemical reactions with type-specific heavy chain myosin antibodies using the indirect peroxidase method (anti-embryonic, anti-neonatal, anti-slow, anti-slow plus IIA, anti-IIB and anti-slow tonic). As a second antibody RAMPO (rabbit anti-mouse peroxidase) was used.

Histochemical characterization of the fibres was done using serial cross-sections of four muscles stained for ATPase, SDH and GPox according to Wirtz, Loermans, Peer \& Reintjes (1983).

For the immunohistochemical stainings, reference sections of the soleus muscle and the extensor digitorum longus (EDL) muscle of the rat were included in the same series of incubation of tensor tympani muscle sections. This was done since the enzyme histochemical fibre type composition of the soleus and EDL is well documented (Zuurveld, Wirtz, Loermans \& Veerkamp, 1985) and a good correlation with the immunohistochemical reactions was found (Reggiani et al., in preparation). For the anti-slow tonic stainings, sections of the tensor tympani muscle of a dog served as a reference, since positively reacting slow tonic fibres are found in this species (Mascarello et al., 1982). For the anti-embryonic and anti-neonatal staining, sections of one-day-old mouse hind limb muscle served as a reference since positively reacting fibres were found in these sections (Reggiani et al., in preparation). The immunohistochemical characterization of the muscle fibre types was compared to the enzyme histochemical characterization.

The cross-sectional area (in $\mu \mathrm{m}^{2}$ ) of the individual fibres was determined with a MOPP videoplan 2000 digitiser. GPox-stained cross-sec- 
tions from the mid-belly of the muscle were used for this purpose. About 400 muscle fibres in a representative area of a crosssection were measured. In addition measurements were made of groups of fibres at successive levels from tendon to tendon. Measurements were made in three different muscles.

For a reconstruction of the anatomical structure of the muscle, $10 \mu \mathrm{m}$ serial frozen cross-sections from the origin to the insertion tendon were collected of three different muscles and stained with Sirius red. For electron microscopy, three muscles were dissected out following perfusion fixation through the heart. Thin sections were double contrasted with uranyl acetate and lead citrate and examined in a Philips electron microscope EM 300.

\subsection{Results}

\subsubsection{Gross anatomy}

The rat tensor tympani muscle is an unipennate muscle with a length of about $3 \mathrm{~mm}$, including the tendons, and a maximal diameter of about $1 \mathrm{~mm}$. Figure 3.1 shows schematically the anatomic relations. The muscle is situated in the medial wall of the middle ear bulla and has a somewhat $\mathrm{C}$-curved shape. A tympanic part and a small tubal part, allong the Eustachian tube, can be distinguished. The tympanic part of the muscle is only partially covered by bone near the Eustachian tube. The small tubal part is situated medial to the Eustachian tube and appears to be in contact with the muscles of the nasopharynx. The insertion tendon is relatively thick and has an angle of $135^{\circ}$ to the belly of the muscle and is attached to the medial processus of the malleus.

\subsubsection{Microscopic anatomy}

Figure 3.2 shows cross-sections stained with Sirius red, at successive levels from origin to insertion.

The muscle is surrounded by a thick epimysium, that can be discerned microscopically from the connective tissue of the tendons and from the 

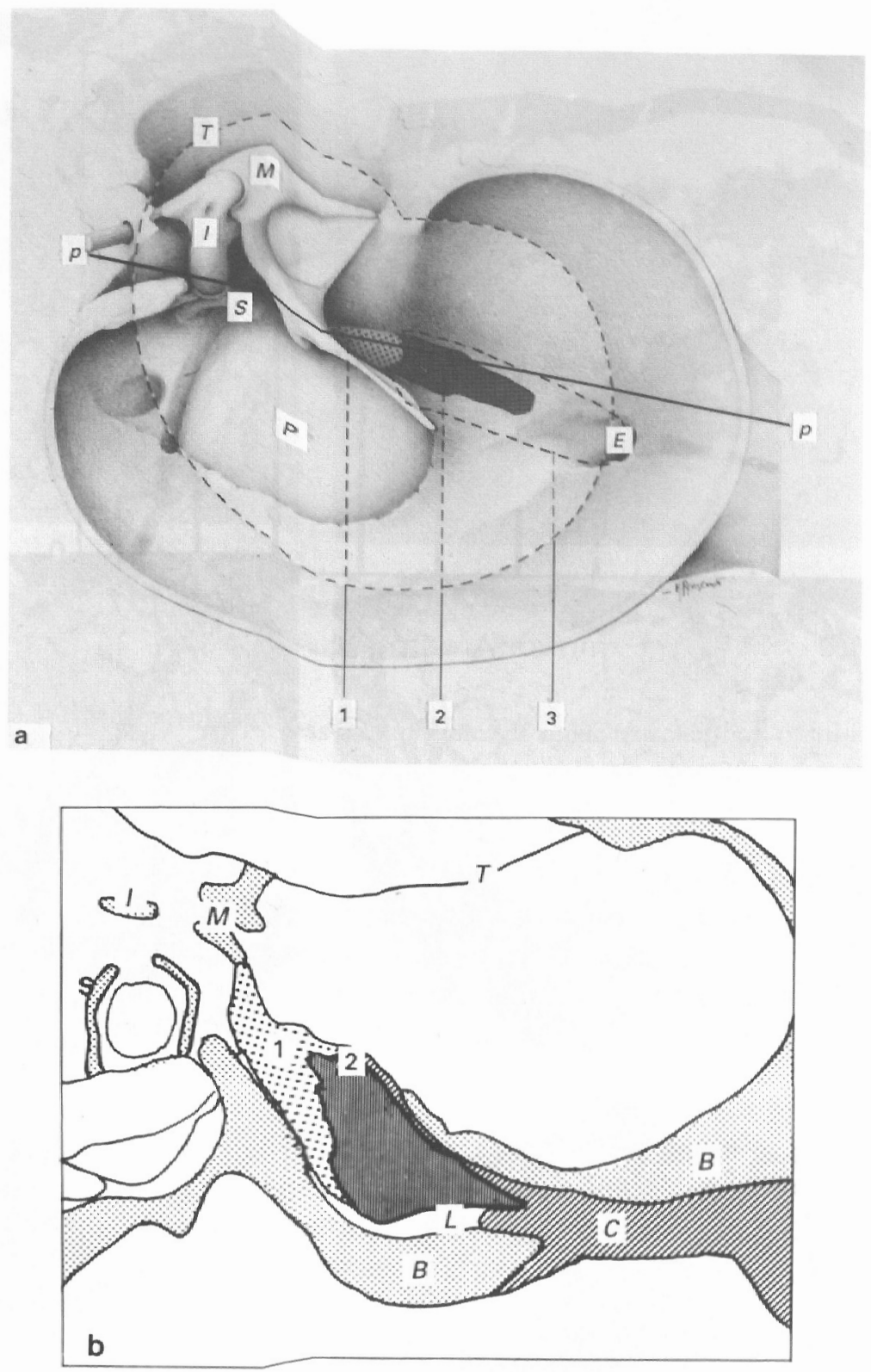

Fig. 3.1 (a-b). Schematic representation of the middle ear bulla of the rat (right ear). (a) Lateral view. (b) Section in the plane of line p-p in (a). T, tympanic membrane; M, malleus; I, incus; S, stapes; $P$, promontory; $E$, orifice of Eustachian tube; L, loose connective tissue; $\mathrm{C}$, connective tissue; $\mathrm{B}$, bone; $1-3$, tensor tympani muscle; 1 , tendon; 2, part of the muscle exposed in bulla; 3 , projection of the whole muscle. 

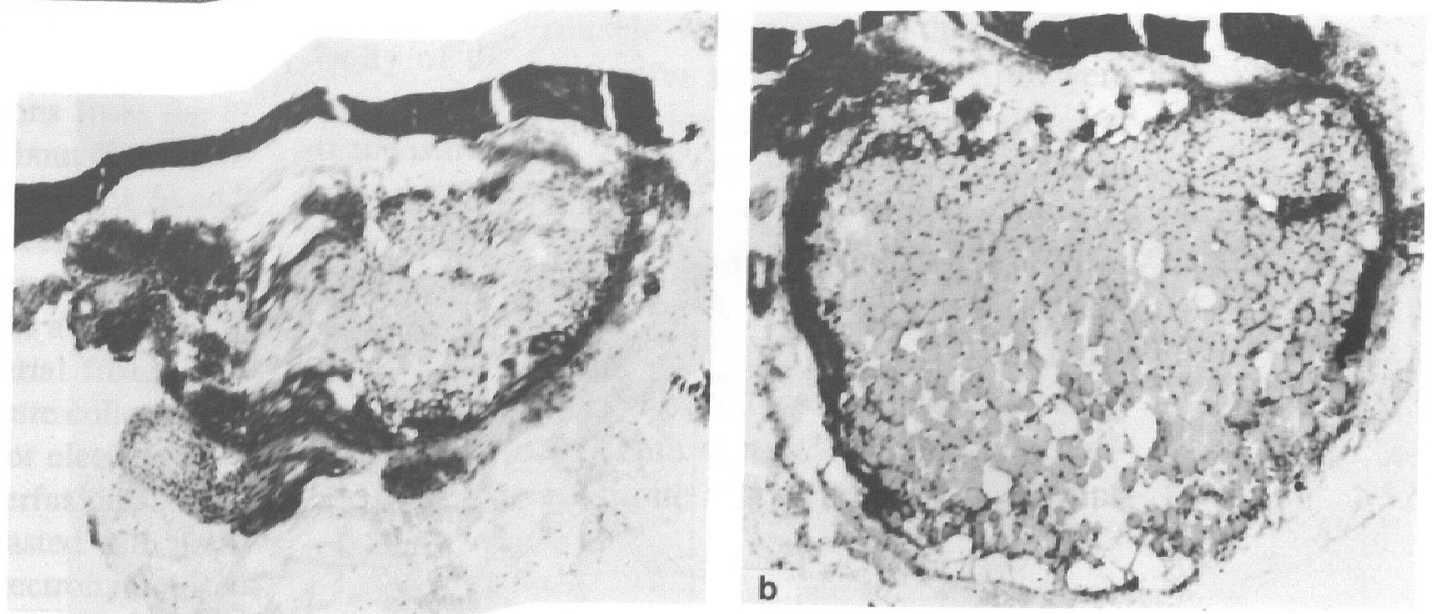

a
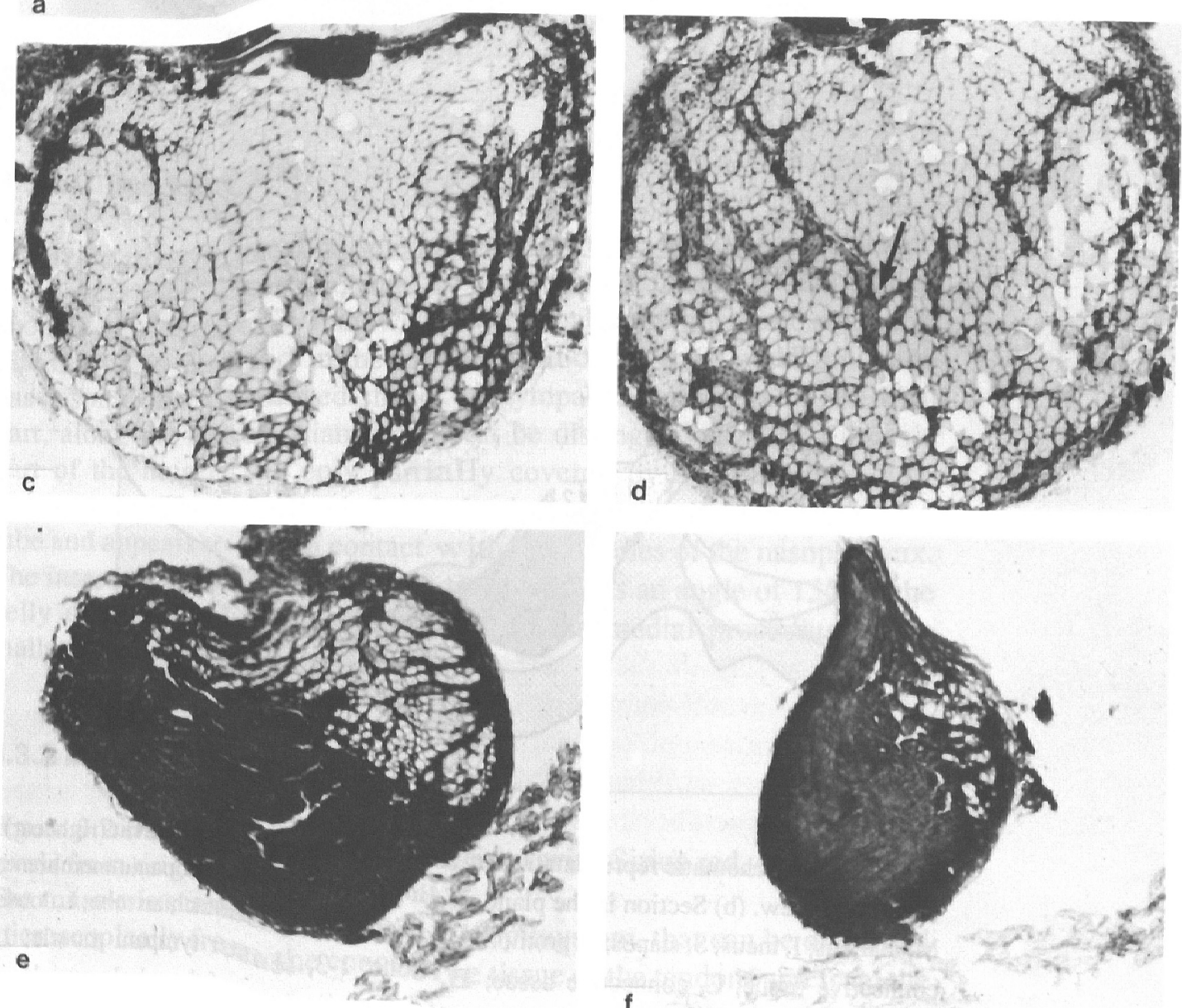


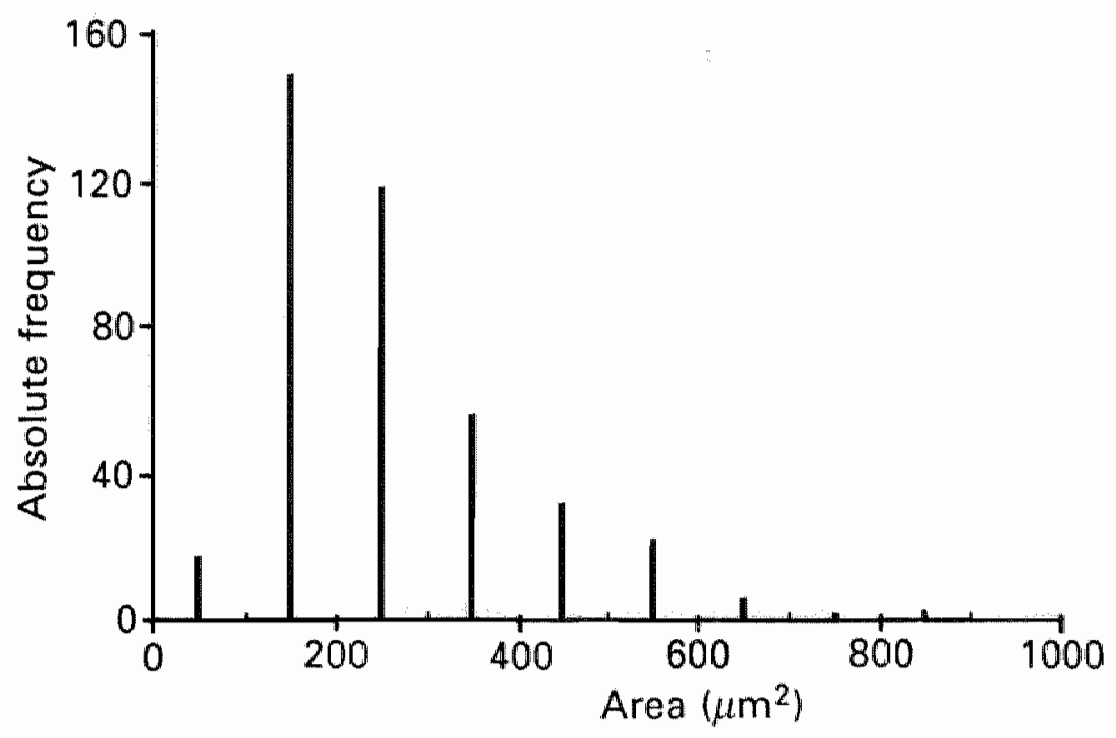

Fig. 3.3: Histogram of the cross-sectional area of single muscle fibres of the rat. $\mathrm{N}=406$. Mean single fibre cross sectional area $259 \mu \mathrm{m}^{2}$; Median $226 \mu \mathrm{m}^{2}$; S.D. 140.

endomysial connective tissue. A loose connective tissue compartment connects the muscle with the periosteum and the bone (Fig. 3.1b).

The muscle fibres are arranged in parallel but not in a very regular fashion. This is mainly due to the extensive, irregular strands of connective tissue that separate the muscle fibres. Scattered between the muscle fibres are fat cells (Fig. 3.2).

Each tendon forms a tendon plate to which the fibres are attached obliquely. This is the most pronounced at the insertion side. The attachment site at the tendon of origin is more or less cup-shaped and encloses the muscle fibres, whereas the insertion tendon tapers alongside the muscle fibres over some distance.

Fig. 3.2 (a-f). Frozen cross sections of an excised tensor tympani muscle of the rat. Sirius red stain. From (a) to (f): Sections at successive levels from origin to insertio. Note the attachment of the tendlons to the muscle compartment. Fat cells present as small white holes in between the muscle fibres. There is extensive nerve branching (arrow). a-f: $x 68$. 
Conspicuous features are the elaborate nerve branches that are contained within the connective tissue strands (Fig. 3.2d).

\subsubsection{Morphometry}

At the site of the largest cross-section, the muscle consists of about 1000 muscle fibres. The mean cross sectional area of a single fibre is $259 \mathrm{\mu m}^{2}$, but the cross-sectional area of the individual muscle fibres shows considerable variation (S.D. 140). Relatively large fibres form the central part of the muscle, whereas smaller fibres dominate in the periphery (Fig. 3.2). The mean single fibre cross-sectional area of the enzyme histochemically typed slow twitch fibres, as measured in various rat tensor tympani muscles, is small $\left(109 \mu \mathrm{m}^{2}\right)$ related to the fast twitch fibres. This results in the histogram (Fig. 3.3) showing a somewhat skewed fibre distribution. Compared to the fibre areas in the belly of the muscle, the fibre areas at the tendon sites are about $45 \%$ smaller (Fig. 3.2e). This indicates tapering of the fibres near the tendons. Qualitatively, no major inter-individual differences were found.

\subsubsection{Enzyme histochemical characterization}

Figure 3.4 shows serial cross-sections stained for, respectively, ATPase ( $\mathrm{pH} 4.35$ ), SDH and GPox, while in Figure 3.5 the occurrence of the various fibre types is indicated schematically. The majority of the fibres reacted weakly with an acid pre-incubated ( $\mathrm{pH} 4.35$ ) ATPase reaction $(98 \%)$. The staining intensity of these fibres for SDH was moderate to strong (Fig. 3.4c), and strong to very strong for GPox (Fig. 3.4e). In many fibres the distribution of the formazan stain for SDH

Fig. 3.4 (a-1). Frozen cross-sections of an excised tensor tympani muscle of the rat. On the left serial sections of respectively ATPase (a), SDH (c) " and GPox (e). On the right $(\mathrm{b}, \mathrm{d}, \mathrm{f})$ details of the corresponding sections. With the ATPase staining $(\mathrm{pH}$ 4.35) most fibres show a weak reaction (fast twitch fibres), only a few fibres being stained dark (slow twitch fibres). Note the strong activity and the atypical (patchy) distribution following SDH and GPox staining. $(a, c, e) \times 85 ;(b, d, f) \times 173$. 


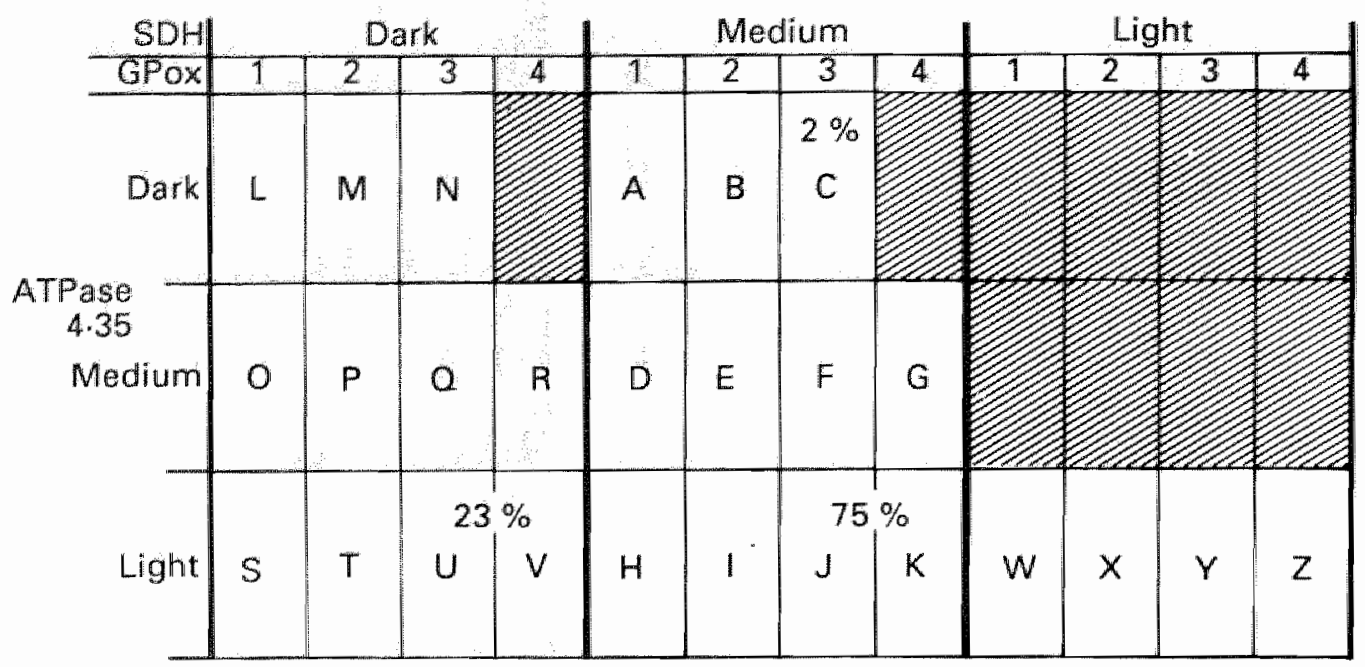

Fig. 3.5. Combination scheme of histochemical reactions (ATPase pH 4.35, SDH and GPox) indicating the different fibre types (Wirtz, et al., 1983). A-C, slow fibres, equivalent to slow oxidative fibres* (SO); D-G, transitional fibres; $L-N$ and $O-R$, rarely occurring fibres; $S-V$, fast red fibres ${ }_{*}$ of these $U$ and $V$ are equivalent to fast oxidative glycolytic* (FOG); H-K, intermediate fibres; W-Z, fast white fibres, of these $\mathrm{Y}$ and $\mathrm{Z}$ are equivalent to fast glycolytic fibres* (FG). The shaded blocks are non-occurring combinations. The figures 1-4 for GPox indicate weak-very strong staining intensity. (* According to Peter et al. 1972).

The percentages of fibre types occurring in the tensor tympani muscle of the rat are indicated in the figure. (SO: 2\%; FOG: $23 \%$; intermediate fibres $75 \%$.)

and GPox was atypically patchy (Fig. 3.4d, f). Electron microscopy revealed the mitochondria to be clustered in these fibres (see below). Based on enzyme histochemical criteria the fibres can be classified as fast oxidative glycolytic fibres, most closely resembling IIA fibres. Two percent of the fibres showed a strong reactivity with ATPase $(\mathrm{pH}$ 4.35) staining. These fibres also revealed a moderate to strong staining intensity with SDH staining and a strong reactivity with GPox staining. In the more acid pre-incubated ATPase stainings ( $\mathrm{pH} 4.1$ and 3.9) these fibres reacted negatively, as they did after alkaline ATPase ( $\mathrm{pH}$ 10.3). Consequently these fibres should be called slow oxydative glycolytic fibres and not IIC fibres. 


\subsubsection{Immunohistochemistry}

Figure 3.6 shows serial cross-sections stained with the various anti heavy chain myosin antibodies.

With the anti-slow antibody (Fig. 3.6d, j), 31\% of the fibres were found to react positively when compared with the reference sections (26\% stained moderately, 5\% stained darkly). Not all fibres staining darkly with the anti-slow antibody were dark in the ATPase staining, but all the dark fibres in the ATPase staining ( $\mathrm{pH} \mathrm{4.35)} \mathrm{also} \mathrm{showed} \mathrm{a}$ strong staining with the anti-slow antibody (Fig. 3.6e, f).

All fibres reacted positively with the anti-slow plus MA antibody (Fig. 3.6c, i). Some small fibres corresponding to the dark fibres in the anti-slow staining showed a more intense staining. Compared to the reference stainings the majority of the fibres showed a positive reaction after incubation with anti-IIIB antibody (Fig. 3.6d, h). They could be clearly distinguished from the background level of the connective tissue. Thus these fibres, too, should be classified as anti-IIB positive. Some small fibres, partly corresponding with the dark fibres in the anti-slow staining showed quite a weak reaction (compare Fig. $3.6 \mathrm{~h}, \mathrm{j}$ ). No fibres reacted positively with the anti-embryonal antibody.

With the anti-neonatal antibody (Fig. $3.6 \mathrm{a}, \mathrm{g}$ ) $29 \%$ of the fibres showed a positive reaction. It appeared that many anti-slow positive fibres also reacted positive for the anti-neonatal antibody (compare $6 \mathrm{~g}, \mathrm{j}$ ).

No fibres reacted positively with the anti-slow tonic antibody, but neither were positive fibres observed in reference sections from a dog.

\subsubsection{Electron microscopy}

Electron microscopy confirmed the abundant collagen fibres in the intercellular compartment, combined with a fair number of fibroblasts. The fibre population could be roughly divided into two groups of fibres according to the arrangement of their organelles. One group was formed by fibres that more or less resembled the fast glycolytic fibres in skeletal muscles of the extremities (Fig. 3.7a). The other group, however, was composed of fibres that possessed a rather atypical ultrastructural organization of bundles of myofilaments and distribution of mitochondria (Fig. 3.7a). Bundles of myofilaments appeared to be branched and interconnected with other bundles of myofilaments 

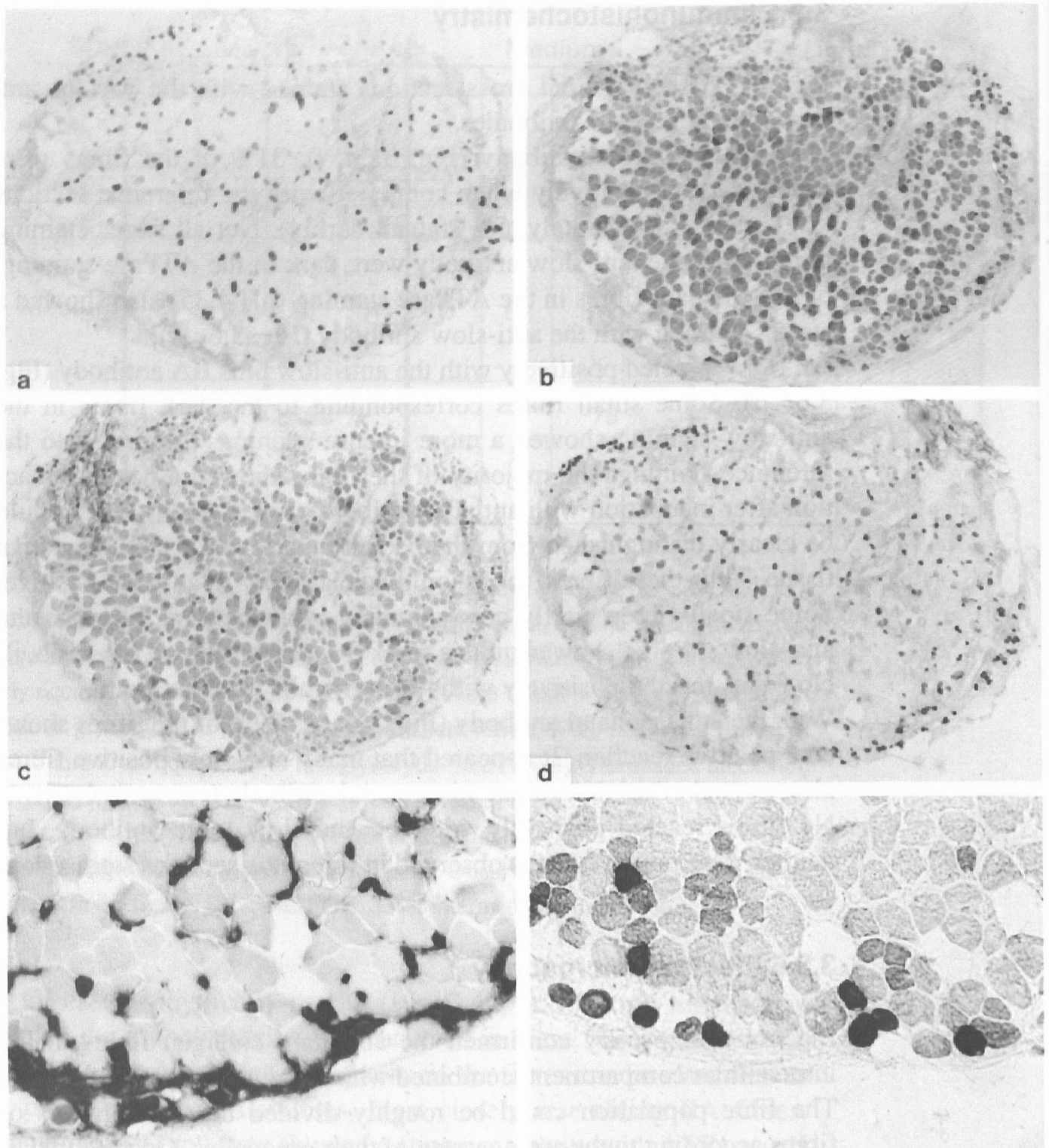

e

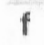

Fig. 3.6 (a-j). Anti-heavy chain myosin stainings of serial-cross sections of the tensor tympani muscle of the rat. (a-d) serial cross-sections; (e-j) details. (a) Anti-neonatal. (b) Anti-IIb. (c) Anti-slow plus IIA. (d) Anti-slow. (e-f) Detail of respectively an ATPase staining ( $\mathrm{pH} 4.35$ ) and the corresponding anti-slow staining. (g-j) Details of (a-d). See text. (a-d) x 56; (e-f) $\times 220 ;(\mathrm{g}-\mathrm{j}) \times 443$. 

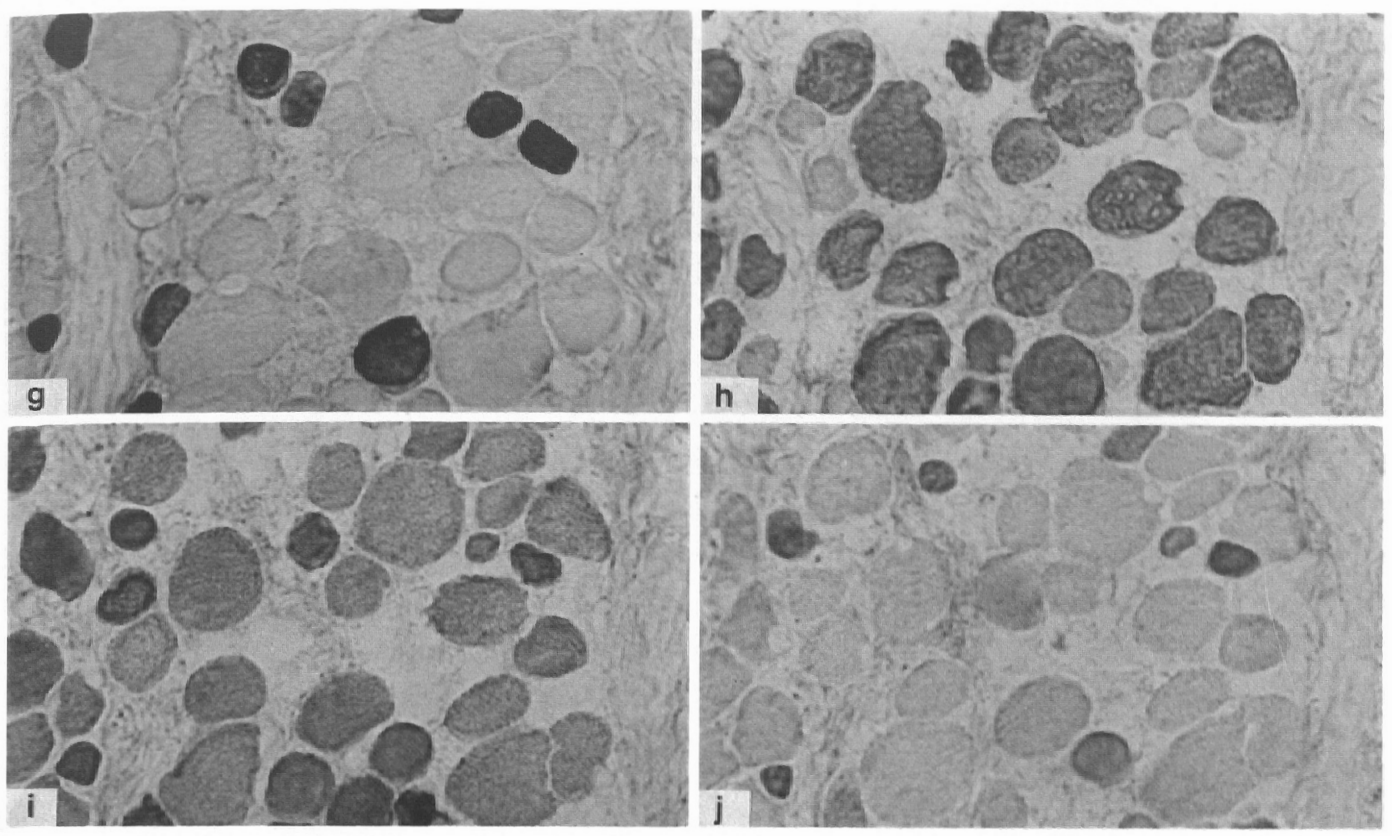

(Fig. 3.7d). In several fibres large subsarcolemmal mitochondria were distributed often in clusters. Also long and elaborate interfilamentous mitochondria were found that easily spanned the length of a sarcomere (Fig. 3.7a, c). Other regions of the fibres were almost lacking in mitochondria. Figure 3.7 shows that the mitochondria of those fibres were distributed in a rather random fashion in contrast to, for instance, the regular pattern of localization in the I-band region in fast glycolytic fibres in skeletal muscles of the extremities. This, together with the branched course of the bundles of myofilaments, resulted in an atypical, i.e. rather disorderly, ultrastructural arrangement of some of the fibres.

\subsection{Discussion}

From our data it appears that, in comparison with other muscles of the rat, the tensor tympani muscle demonstrates several atypical features giving rise to interesting speculations about its function. The data 

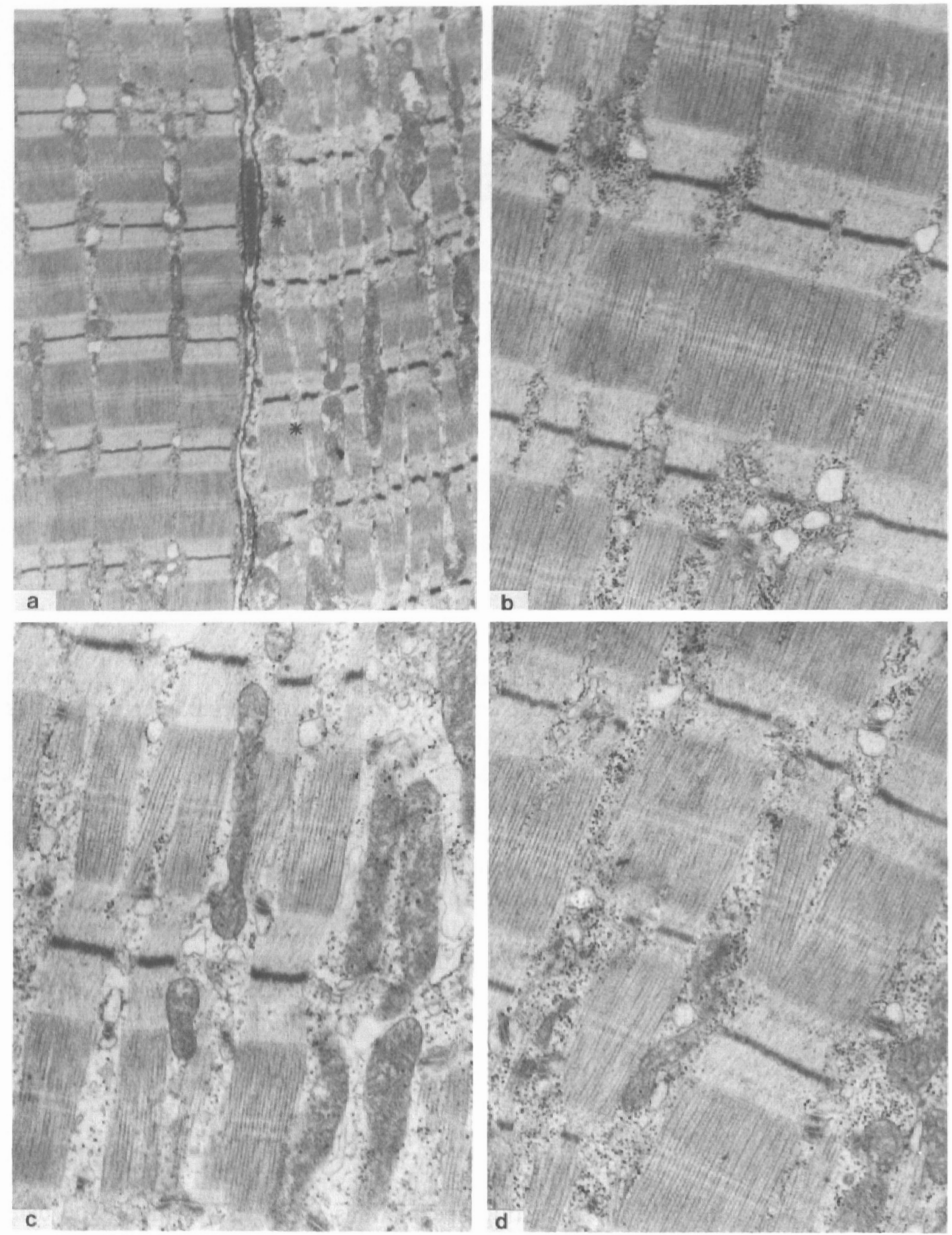
collected in this study strongly suggest that the tensor tympani muscle displays an almost isometric contraction pattern.

In situ the muscle is C-shaped; the tendon of insertion is connected to the muscle fibres at an obtuse angle. Because the tubal part of the muscle is hardly covered by bone and because a loose connective tissue forms a sleeve between the attachement of the muscle and the bone, one would expect a relatively large range of motion to be possible at the site of attachement on the malleus when the muscle contracts. However several factors may be considered to restrict the range of motion. First of all, the oblique attachment of the muscle fibres to the tendon of insertion diminishes the effective contraction force, and thereby the amplitude of motion (Close, 1964; Mascarello, 1982). Secondly, since the main part of the muscle is not covered by bone and a large part of the muscle is connected to the bone by a loose connective tissue, the angle between the muscle fibres and the bone becomes more obtuse upon contraction, a feature we observed in vivo, resulting in less motion at the insertion site. Furthermore, the low compliance of the chain of ossicles and the tympanic membrane diminishes the possible amplitude of motion.

The muscle is also likely to exert an important influence on the dynamics of the chain of ossicles in a static situation: the tendon of insertion is relatively thick as in many mammals (Kobayashi, 1956) which undoubtedly influences the dynamic characteristics of the chain and thereby the transmission of sound by a damping effect. The role of the fat cells remains uncertain. In tensor tympani muscles of various mammals fat cells have been described (Kobayashi, 1956). Theories about a function related to the dynamics of the muscle and also about a metabolic function have been postulated (see, for references: Anderson, 1976). In view of our metabolic observations we favour the latter opinion.

Fig. 3.7 (a-d). Electron microscopy of longitudinal sections of the tensor tympani muscle of the rat. (a) Two muscle fibres. The fibre on the right has a large number of more elaborate mitochondria than that on the left. Branching of myofilaments bundles can be seen in the fibre on the right (*). (b) Detail of the fibre on the left in (a). (c) Detail of the fibre on the right in (a). Note large mitochondria with many cristae occuring in clusters. (d) Detail of a branching bundle of myofilaments. (a) $x$ 5650; (b-d) x 16800. 
With electron microscopy we observed branching of bundles of myofilaments which interconnect with other bundles, a feature not found in normal skeletal muscle. In heart muscle branching of bundles of myofilaments does occur, but they do not interconnect with each other. It seems therefore that on contraction of the muscle, in addition to longitudinal forces, transverse forces are also being developed:

The features mentioned above all would fit in the concept of an isometric contraction pattern of the musculus tensor tympani in the rat. Furthermore, the enzyme histochemical and immunohistochemical data point to other peculiar functional characteristics of this middle ear muscle. All fibres showed a high aerobic and a high glycolytic capacity. Thus the fast fibres $(98 \%)$ should be classified as fast oxidative glycolytic and the slow fibres (2\%) as slow oxidative glycolytic. The latter are not the classical type I fibres, due to their high glycolytic capacity.

Contrary to skeletal muscles of the extremities, classification of the muscle fibres of the tensor typani muscle according to immunohistochemistry was difficult. First of all, far more type I fibres were found with anti-slow antibodies, than with ATP-ase as a marker (respectively $31 \%$ and $2 \%$ ).

There is no disagreement about the majority of the fibres being of a fast twitch type, but unlike normal adult skeletal muscles, e.g. of the extremities, many of the fibres reacted positively with both the antiIIA and anti-IIB antibodies. Moreover, about one third of the fibres reacted positively with the anti-neonatal antibody. In adult skeletal muscle this myosin is absent (Schiaffino et al., 1988). Fibres positive for the anti-slow tonic antibody were not found, but our experiments are not conclusive since reference sections of a dog tensor tympani muscle did not reveal positive fibres either, in contrast to what was found by Mascarello et al., (1982).

The above-mentioned immunohistochemical findings show that several heavy chain myosins can be present within one fibre, even in what would appear to be a rather well differentiated striated muscle fibre of the tensor tympani. The fibres do contain the adult myosin types but in contrast to normal skeletal muscle, they are found together in one fibre. Supposedly, genes coding for the various myosin heavy chains continue to be activated, and possibly do so in different nuclei that are contained in the syncytium. During normal postnatal development gene activation and inactivation is a regular feature that, among others, 
regulates the successive production of myosin iso-types such as embryonic, neonatal, slow and fast. But in this case the co-occurrence of several myosin iso-types in a muscle fibre merely indicates a transitional situation. There are no indications that such a situation exists in the middle ear muscle we studied. The biological significance of the co-expression of different myosin fibres in well differentiated muscle fibres, therefore, remains enigmatic.

When translating the enzyme and immunohistochemical characteristics into terms of function the concept of a muscle with the potential of a fast contraction pattern and a high fatigue resistance becomes apparent. From our data the tensor tympani muscle of the rat emerges as a muscle with an almost isometric contraction pattern, the fibres of which are fast to contract and at the same time fatique-resistant. These characteristics, in our opinion, endow the muscle with perfect properties to serve a function in protecting the ear from loud noise over longer periods of time. Electrophysiological studies, necessary to confirm this concept, are in progress.

\section{Acknowledgements}

We thank Prof. S. Schiaffino and Dr. F. Mascarello for kindly providing the myosin antibodies, L. Lubbers, A. v. Geest and H.M.Th. Loermans for technical assistance, and $\mathrm{H}$. Rensema for drawing Figure 3.1a. We thank Prof. dr. J.W. Arends from the Department of Pathology, University of Maastricht, for his constructive comment on the manuscript and Dr. P. Jap, from the department of Cell Biology and Histology, University of Nijmegen, for his contribution to the interpretation of the electron microscopy. 


\subsection{References}

Anderson, S.D. (1975). Peripheral aspects of the physiology of middle ear muscles. Symposia of the Zoologicial Society of London 37,69-95.

Anders on, S.D. (1976). The intratympanic muscles. In: Scientific Foundations of Otolaryngology (Ed: R. Hinchcliffe \& D. Harrison). London: William Heinemann Medical Books Ltd.

Blevins, C.E. (1963). Innervation of the tensor tympani muscle of the cat. American Journal of Anatomy 113,287-301.

Borg, E., Counter, S.A. \& Rosler, G. (1984). Theories about middle ear muscle function. In: The acoustic reflex; Basic principles and clinical applications. (ed. S. Silman). Orlando. Florida: Academic Press.

Borg, E. \& Nilsson, N. (1984). Acoustic reflex in industrial noise. In: The acoustic reflex; Basic principles and clinical applications. (ed. S. Silman). Orlando. Florida: Academic Press.

Brzezinski, D.K. von (1962). Fieinbau, Musclespindeln und Funktion der Mittelohrenmusceln des Menschen. Archiw für Ohren-, Nasen- und Kehlkophheilkunde $179,550-566$.

Close, R.I. (1964). Dynamic properties of fast and slow skeletal muscles of the rat during development. Journal of Physiology 173, 74-95.

David, H., Gerhardt, H.J. \& Uerlings, I. (1966). Die submikroskopische Struktur des Musculus Stapedius des Meerschweinchens. Zeitschrift fur Zellforschung und milkroskopische Anatomie 70, 334-346.

Dubowitz, V. \& Brooke, M.H. (1973). Muscle biopsy: A modern approach. London: W.B. Saunders.

Fernand, V.S.V. \& Hess, A. (1969). The occurrence, structure and innervation of slow and twitch muscle fibres in the tensor tympani and stapedius of the cat. Jourmal of Physiology 200, 547-554.

Gerhardt, H.J., David, H. \& Marx, 1. (1966). Electronen-mikroskopische Untersuchungen am Musculus tensor tympani des Meerschweinchens. Archiv fuer klinisch und experimentelle Ohren-, Nasen- und Kehlkopfheilkunde 186, 2030.

Guthrie, D. (1940). The history of otology. Joumal of Laryngology and Otology $55,473-494$.

Haugsten, P., Bendiksen, F.S., Dahl, H.A. \& Teig, E. (1982). The motor innervation pattern of cat tensor tympani as revealed by histochemical study of serial cross sections. Acta Otolaryngologica, Suppl. 386, 291-295. 
Haugsten, P., Dahl, H.A. \& Teig, E. (1984). Histochemical characteristics of the tensor tympani muscle in relation to the medial gastrocnemins muscle of the cat. Acta Otolaryngologica 98, 221-230.

Hirayama, M., Davidowitz, J. \& Daly, J.F. (1974). Ultrastructure of middle car muscle in the rabbit. II. Tensor tympani. Acta Otolaryngologica 77, 171-175.

Jong, F.I.C.R.S. de, Kingma, H., Wirtz, P., Berge, H. van den \& Marres, E.H.M.A. (1988). Indications of a differentiated regulation of sound transmission by the middle ear muscles of the rat. Joumal of Otology $9,70-75$.

Kobayashi, M. (1956). Comparative anatomical studies of the morphology of the tensor tymani muscles of various mammals. Hirochima Joumal of Medical Science 5, 85-108.

Krebs, P. (1905). Die Nervenendigungen im Musculus stapedius mit besondere Bericksichtigung der bei der Färbung angewandten Technik. Archiv fur mikroskopische Anatomie und Entwicklungsmechanik 65, 704-718.

Lubbers, L., Loermans, H. \& Wirtz, P. (1988). Sirius rood kleuring voor vriescoupes: een modificatie volgens Lubbers. Histotechniek $6(5), 99-100$.

Malan, E. (1934). Morfologica comparta del muscolo "tensor tympani". Zeitschrift für Anatomie und Entwicklungsgeschichte 103, 409-437.

Malmfors T. \& Wersäll, J. (1960). Innervation of the middle ear muscles of the rabbit with special reference to nerve calibres and motor units. I. Musculus tensor tympani. Acta Morphologica Neerlando Scandinavica 2, 157-162.

Mascarello, F., Carpenè, E., Vegetti, A., Rowlerson, A. \& Jenny, E. (1982). Tensor tympani muscle of cat and dog contains IIM and slow-tonic fibres: an unusual combination of fibre types. Journal of Muscle Research and Cell Motility 3, 363-374.

Mascarello, Fu, Vegetti, A., Carpenè, E. \& Rowlerson, A. (1983). An immunohistochemical study of the middle ear muscles of some carnivores and primates, with special reference to the IIM and slow-tonic fibre types. Journal of Anatomy $137,95-108$.

Meijer, A.E.F.H. \& De Vries, G.P. (1978). Enzyme histochemical studies of the Purkinje fibres of the atrioventricular system of bovine and porcine hearts. Histochemical Journal 10, 399-408.

Nachlas, M.M., Tsou, K.C., De Souza, E., Cheng, C.S. \& Seligman, A.M. (1957). Cytochemical demonstration of succinic dehydrogenase by the use of a new p-nitrophenyl substituted ditetrazole. Journal of Histochemistry and Cytochemistry $5,420-436$.

Padykula H.A. \& Herman, E. (1955). The specificity of the histochemical method of adenosine triphosphatase. Journal of Histochemistry and Cytochemistry 3 , 170-195. 
Peter, P. B., Barnard, R.J., Edgerton, V.R., Gillespie, C.A. \& Stempel, K.E. (1972). Metabolic profiles of three fiber types of skeletal muscle in guinea pigs and rabbits. Biochemistry 11, 2627-2633.

Schiaffino, S., Gorza, L., Pitton, G., Saggin, L., Ausoni, S., Sartore, S. \& Lömo, T. (1988). Embryonic and neonatal myosin heavy chain in denervated and paralyzed rat skeletal muscle. Developmental Biology 127 , (1) 1-11.

Spiesman, 1.G. (1927). Ueber die Fetteinlagerungen im Muskulus tensor tympani am gesunden und am kranken Ohr nebst Entwicklungsgeschichtlichen und vergleichend anatomischen Bemerkungen. Monatsschrift fuer Ohrenheilkunde und Laryngo-Rhinology 61, 969-983.

Sweat, F, Puchtler, H. \& Rosenthal, S.I. (1964). Sirius red F3BA as a stain for connective tissue. Archives of Pathology 78, 69-72.

Vegetti, A., Mascarello, F. \& Carpenè, E. (1982). A comparative histochemical study of fibre types in middle ear muscles. Journal of Anatomy 135, 333-352.

Wattenberg, L.W. \& Leong, J.L. (1960). Effects of coenzyme Q-10 and menadione on succinic dehydrogenase activity as measured by tetrazolium salt reduction. Journal of Histochemistry and Cytochemistry 8, 296-303.

Wirtz, P., Loermans, H.M.Th., Peer, P.G.M. \& Reintjes, A.G.M. (1983). Postnatal growth and differentiation of muscle fibres in the mouse. I. A histochemical and morphometrical investigation of normal muscle. Journal of Anatomy 137, 109-126.

Zuckerkandl, E. (1884). Zur Morphologie des Musculus tensor tympani. Archiv für Ohrenheilkunde 20, 104-120.

Zuurveld, J.G.E.M., Wirtz, P., Loermans, H.M.Th. \& Veerkamp, I.H. (1985). Postnatal growth and differentiation in three hindlimb muscles of the rat. Cell and Tissue Research 241, 183-192. 


\title{
CHAPTER 4
}

\section{Detailed morphology of the stapedius muscle of the rat}

\author{
An integrated light microscopical, morphometrical, \\ histochemical, immunohistochemical and electron \\ microscopical study in relation to function.
}

\section{Summary}

The stapedius muscle of the rat, a very small muscle, appeared to have several atypical morphological characteristics. The muscle fibres were found to be irregularly shaped and composed of relatively small bundles of myofibrils. Mitochondria were distributed irregularly, i.e. in long strands, between the bundles of myofibrils. Enzyme histochemically, most fibres could be classified as fast oxidative glycolytic fibres (IIA). Only $5 \%$ of the fibres appeared to be slow twitch fibres; however, these fibres also had a high glycolytic capacity, and therefore could not be classified as the classical slow twitch fibres. The immunohistochemical staining with monoclonal anti-heavy chain myosin isotypes showed discrepancies when compared to the enzyme histochemical results. Moreover, different adult heavy chain myosin isotypes appeared to coexist in one single muscle fibre.

The results suggest that the muscle has an isometric contraction pattern and that the muscle can contract rapidly with great endurance. This endows the muscle with properties to have function in the prevention of noise-induced hearing loss and also in impact noise over longer periods of time.

Berge, H. van den \& Wirtz, P. (1989).

Journal of Anatomy 166, 157-169. 


\subsection{Introduction}

The middle ear muscle reflex is an important input control mechanism for the inner ear. By modulating sound transmission over the ossicular chain the tensor tympani and the stapedius muscle can protect the inner ear from noise-induced hearing loss and increase the sensitivity of the hearing system (Borg, Counter \& Roosler, 1984). The reflex is elicited by self-phonation and loud acoustic stimuli, but it can also be activated by certain tactile stimuli (Djupesland, 1964). Electrophysiological studies showed considerable interspecies differences and it seems that the function pattern is adapted to the special needs of the individual mammal. Despite the investigations on the middle ear muscle reflex in the past many questions remain. For example, when considering the role in the protection against noise, more detailed information about the fatiguability, the latency and the contraction time of the reflex has to be obtained. To obtain clues in answering these physiological questions a thorough knowledge of the functional morphology of the muscles is necessary.

Anatomical studies of the muscles in the past were mostly fragmentary, i.e. without integration of the various morphological aspects in one animal species (For references see Berge \& Wirtz, 1989). Such an integration is important since major morphological interspecies differences appear to exist (Kobayashi, 1956; Vegetti, Mascarello \& Carpenè, 1982; Mascarello, Vegetti, Carpenè \& Rowlerson, 1983).

The aim of our study is to create an integrated insight into structure and function of the middle ear muscles in the rat. Results of the functional morphology of the tensor tympani muscle of the rat and preliminary electrophysiological studies have been previously published (Jong et al., 1988; Berge \& Wirtz, 1989). In this article the gross anatomy, microscopic anatomy, muscle fibre morphometry, enzyme histochemistry, immunohistochemistry and electron microscopy of the stapedius muscle of the rat are presented, and the functional implications are discussed. 


\subsection{Materials and methods}

Following examination of the anatomy in vivo, ten stapedius muscles were removed from five 12 weeks old male Lewis rats during sodium pentobarbital anaesthesia. Serial cryosections of $10 \mu \mathrm{m}$ were made and the following staining techniques were applied: (a) Sirius red; (b) myofibrillar ATPase (pre-incubation $\mathrm{pH}: 9.4,4.6,4.3,4.0$ and 3.9); (c) succinic-dehydrogenase (SDH); (d) alpha glycerophosphate dehydrogenase (GPox); (e) immunohistochemical reactions against myosin heavy chain isotypes (anti-embryonic, anti-neonatal, anti-slow, antislow plus IIA, anti-IIB and anti-slow tonic). Reference stainings of the extensor digitorum longus muscle (EDL) and soleus muscle of the rat were included in the same series of incubations for the enzyme histochemical and immunohistochemical reactions of the stapedius muscles (for references and detailed information about the technical procedures see Berge \& Wirtz, 1989).

Histochemical characterization of the fibres was done on four muscles using serial sections stained for ATPase, SDH and GPox (Berge \& Wirtz, 1989).

The cross-sectional area (in $\mu \mathrm{m}^{2}$ ), and the smallest diameter of the individual fibres were determined with an MOPP videoplan 2000 digitiser. Sirius red-stained cross-sections from the mid-belly of the muscle were used for this purpose. In most cross-sections some of the muscle fibres were not cut exactly in a transverse plane and care had to be taken to prevent bias in the measurements of the cross-sectional area. Therefore as well as measurements of the cross sectional area, measurements were made of the smallest diameter. To check the results, measurements were made in three different muscles.

For a reconstruction of the anatomical structure of the muscle $10 \mu \mathrm{m}$ serial frozen cross-sections from the origin to the tendon of insertion were collected from three different muscles and stained with Sirius red.

For electron microscopy, three muscles were dissected following perfusion fixation through the heart (Berge \& Wirtz, 1989).

In order to study and to present the in situ orientation and localization of the stapedius muscle in relation to other structures in the middle ear, serial sections of decalcified middle ear bullas were made. 

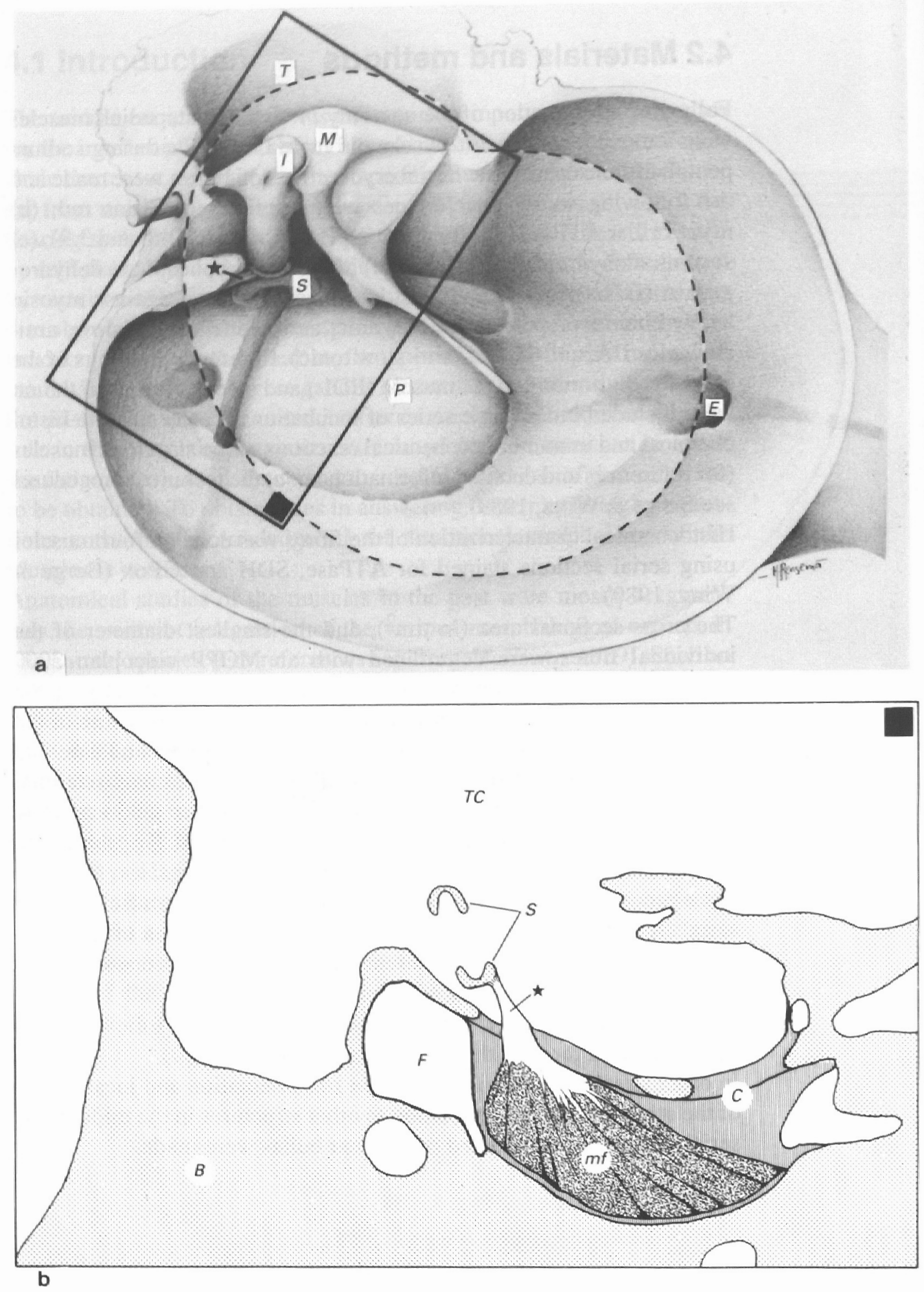


\subsection{Results}

\subsubsection{Gross anatomy}

The stapedius muscle of the rat is about $1.2 \mathrm{~mm}$ long and has a diameter of approximately $0.6 \mathrm{~mm}$. Figure 4.1 schematically shows the anatomical relations. In situ the muscle has a hemi-ellipsoid configuration. It is embedded in the dorsomedial wall of the middle ear bulla and the dorsocranial aspect of the muscle is in close relation to the facial nerve. A small longitudinal part of the muscle is presented to the tympanic cavity by a slit in the bony dorsomedial wall. The very thin insertion tendon enters the bulla through this slit and is attached to the dorsal crus of the stapes at an angle of $180^{\circ}$ to a plane through both crurae of the stapes. On the site facing the tympanic cavity the muscle is covered by a relatively thick fibrous tissue plate onto which the epimysium is attached. On the opposite site, the muscle fibres are attached via the epimysium to the bone of the concave cavity in which the muscle is situated.

\subsubsection{Microscopic anatomy}

Figure 4.2 shows cross-sections, stained with Sirius red, at successive levels from origin to insertion.

As can be seen in the figure the muscle is surrounded by a thin perimysium, which is attached to a relatively thick fibrous tissue plate on the bulla side. The muscle is devided into compartments by irregular strands of fibrous tissue. These contain blood vessels and an elaborate network of nerve fibres (Fig. 4.2c), the latter arising from the stapedial nerve that enters the muscle near the insertion tendon (Fig. 4.2a).

Fig. 4.1 ( $a, b)$. Schematic representation of the middle ear bulla of the rat (right ear). (a) Lateral view. (b) Section of the area indicated in (a). B, bone; C, connective tissue; $E$, orifice of Eustachian tube; $F$, facial nerve; 1 , incus; $M$, malleus; $M F$, muscle fibres; $\mathrm{P}$, promontory; $\mathrm{S}$, stapes; $\mathrm{T}$, tympanic membrane; $\mathrm{TC}$, tympanic cavity; asterisk, tendon of the stapedius muscle. 


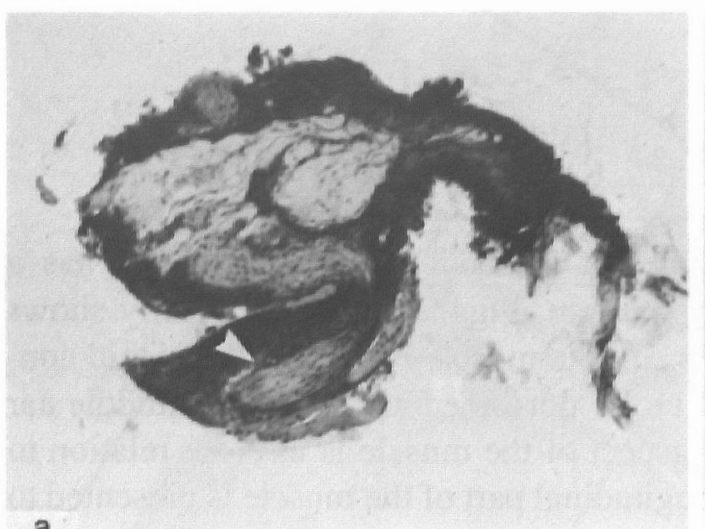

a

b
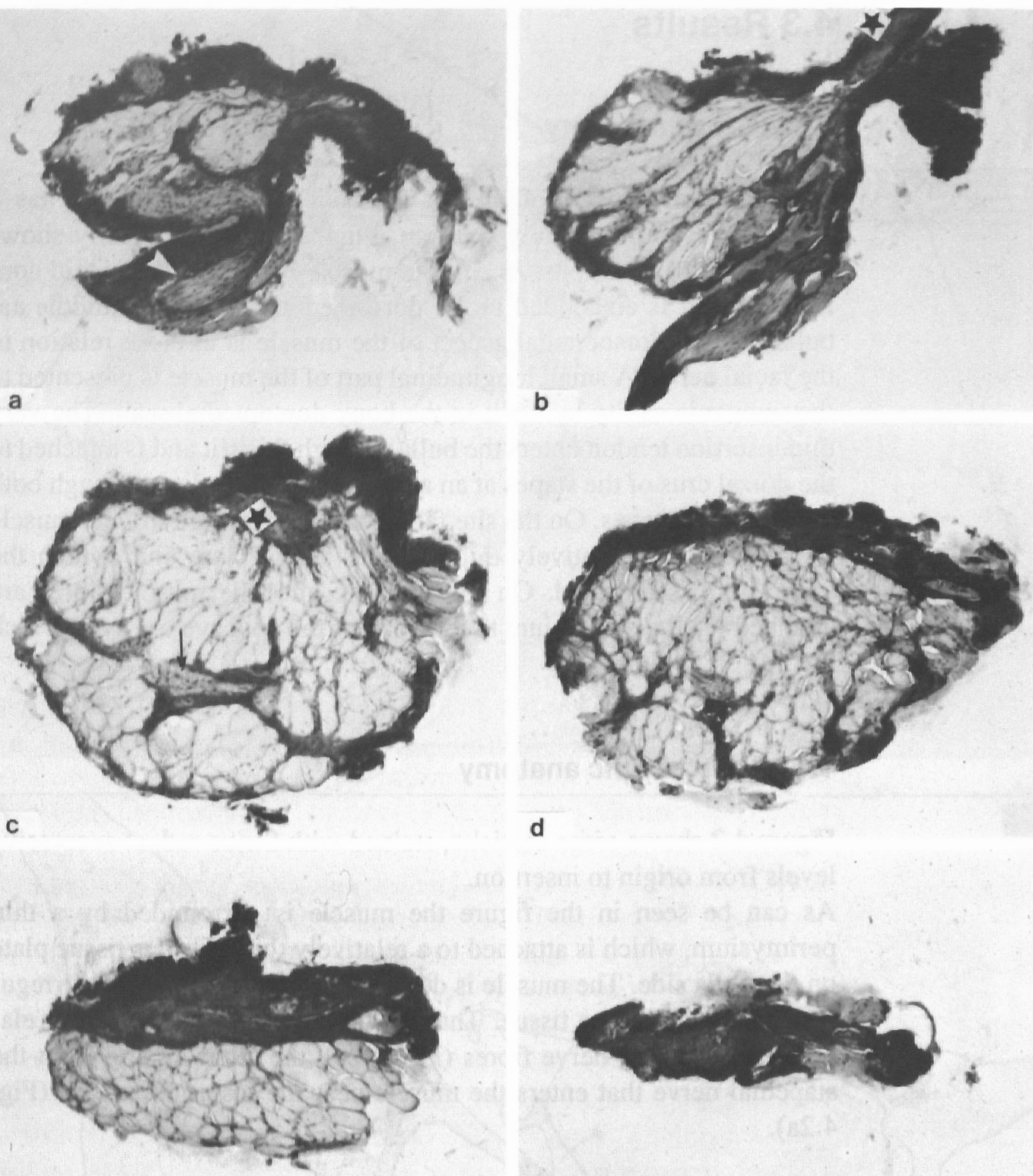

e

Fig. 4.2 (a-f). Frozen cross sections of an excised stapedius muscle of the rat. Sirius red stainings. From (a) to (f): sections at successive levels from origin to insertion. (a) white arrowhead, stapedial nerve; (b,c) asterisk, tendon; (c) arrow, branched nerve. (a-f) $\times 76$. 
The muscle fibres are arranged mainly in parallel, but not in a very regular way, due to the irregular strands of fibrous tissue. At the insertion site the muscle fibres convert to the paracentrally situated tendon. As a result, upon cross-sections, the muscle fibres in this area are cut obliquely (Fig. $4.2 \mathrm{~b}, \mathrm{c}$ ). A very thin insertion tendon connects the muscle to the stapes. In contrast to findings in the tensor tympani muscle of the rat, no fat cells were encountered.

\subsubsection{Morphometry}

The largest cross-section of the muscle consists of about 300 muscle fibres. Figure 4.3 shows the histogram of smallest diameter of individual muscle fibres. The mean smallest diameter of a single muscle fibre was $25 \mu \mathrm{m}$ with standard deviation (S.D.) of 8.3 indicating much variation in fibre size. The mean cross-sectional area was $782 \mu \mathrm{m}^{2}$ (S.D. 443). Measurements in two other muscles were in good agreement with those of the muscle presented.

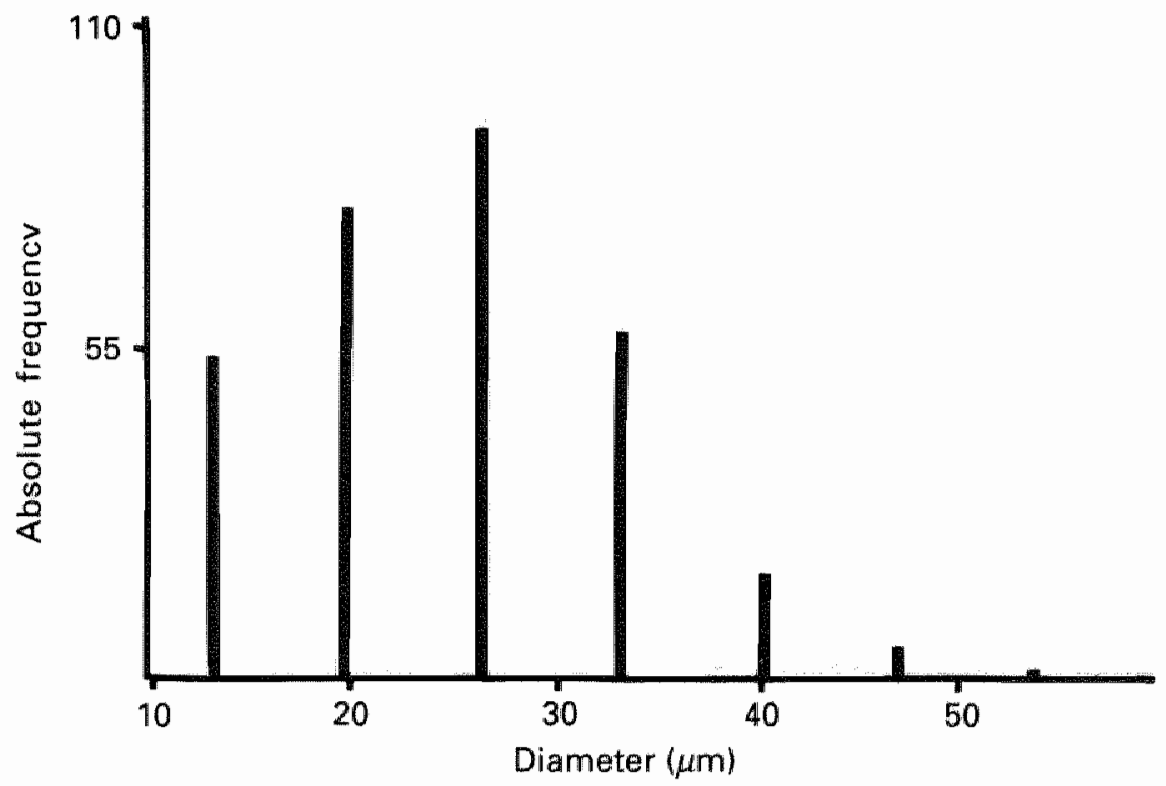

Fig. 4.3. Histogram of the smallest diameter, ${ }$ of single muscle fibres of the stapedius muscle of the rat. $\mathrm{N}=315$. Mean single smallest diameter $25 \mu \mathrm{m}$; median $24.7 \mu \mathrm{m}$; S.D. 8.4 . 


\subsubsection{Enzyme histochemistry}

Figure 4.4 shows serial cross sections stained for, respectively, ATPase, SDH and GPox, while in Figure 4.5 the occurrence of the various fibre types is indicated schematically. The enzyme histochemical figures presented below are mean figures, derived from three different muscles. All three muscles showed a similar fibre type composition.

Upon ATPase ( $\mathrm{pH} 4.35$ ) staining the majority of the muscle fibres reacted negatively $(87 \%)$ and thus can be considered to be fast twitch fibres. A small part revealed a weak to moderate reaction ( $8 \%$ ) (Fig. $4.4 \mathrm{a}, \mathrm{b})$. All these fibres showed a moderate to strong reaction on both the SDH and the GPox staining (Fig. 4.4c-f), indicating a high oxidative as well as a high glycolytic capacity respectively. Qualitatively the SDH and Gpox reactions showed a patchy staining pattern (Fig. 4.4d, f), indicating an uneven distribution of formazan.

Only a small part of the fibres reacted positively on the ATPase ( $\mathrm{pH}$ 4.35 ) reaction (5\%). With the ATPase pre-incubation at $\mathrm{pH} 3,9$ and $\mathrm{pH}$ 9.4 these fibres reacted negatively. As a result they should be considered as slow twitch fibres. In the acid pre-incubation (pH 3.9 and 4.0) no indication of the presence of IIc fibres could be found. Like the fast twitch fibres, the slow twitch fibres reacted in a moderate to strong way with both the SDH and GPox staining.

In summary, enzymhistochemically the stapedius muscle is mainly composed of fast twitch fibres with a relatively high oxidative and glycolytic capacity, most closely resembling type MA fibres (95\%). A small part of the muscle fibres is slow twitch (5\%). These fibres, too, have a high oxidative and glycolytic capacity. Therefore they are not cllassical type I fibres (=slow oxidative).

Fig. 4.4 (a-f). Frozen cross sections of an excised stapedius muscle of the rat. On the left: serial sections of respectively ATPase ( $\mathrm{pH}$ 4.35) (a), SDH (c), and GPox (e). On the right $(b, d, f)$ : details of the corresponding sections. (a, c, e) $\times 89 ;(b, d, f) \times$ 462. 

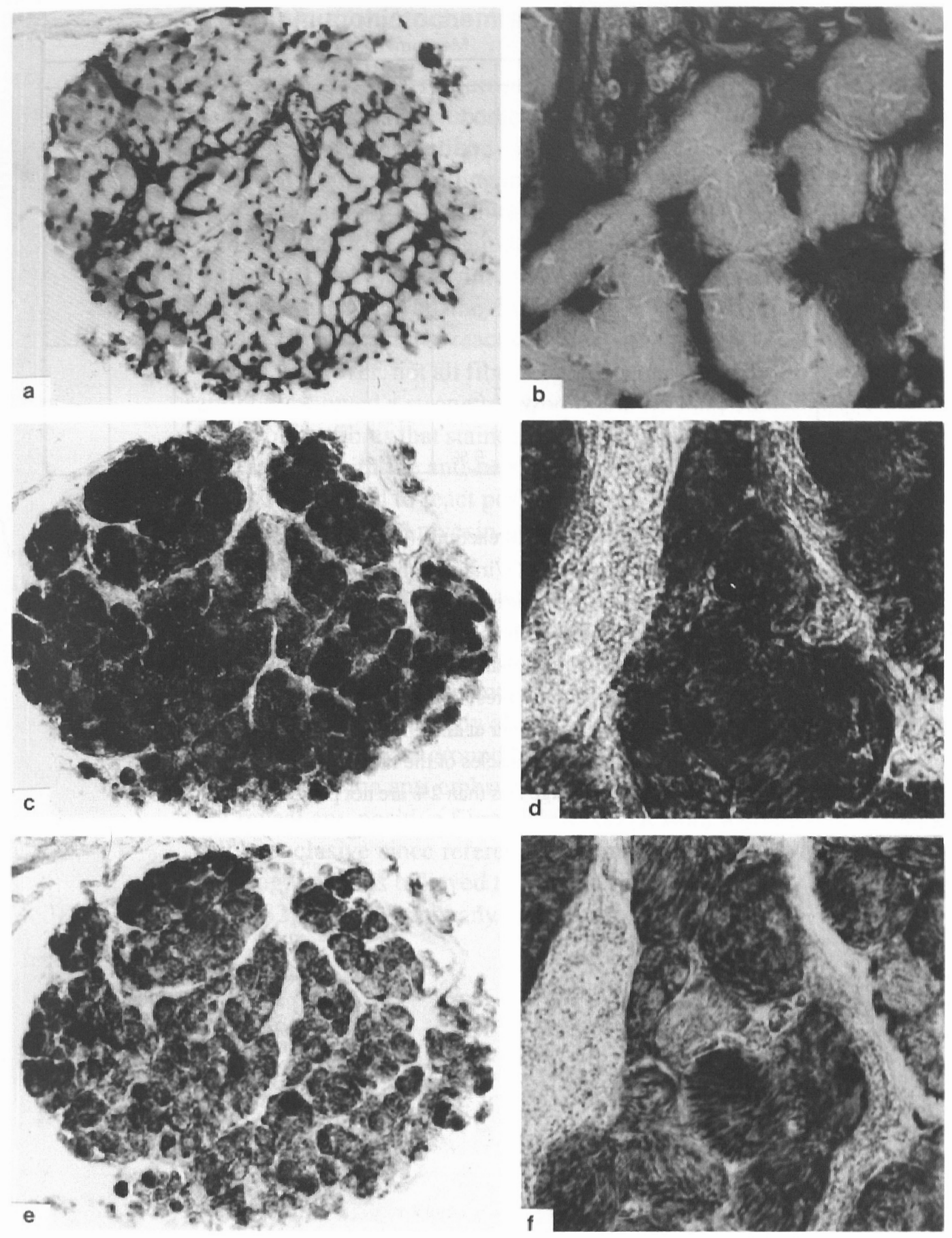


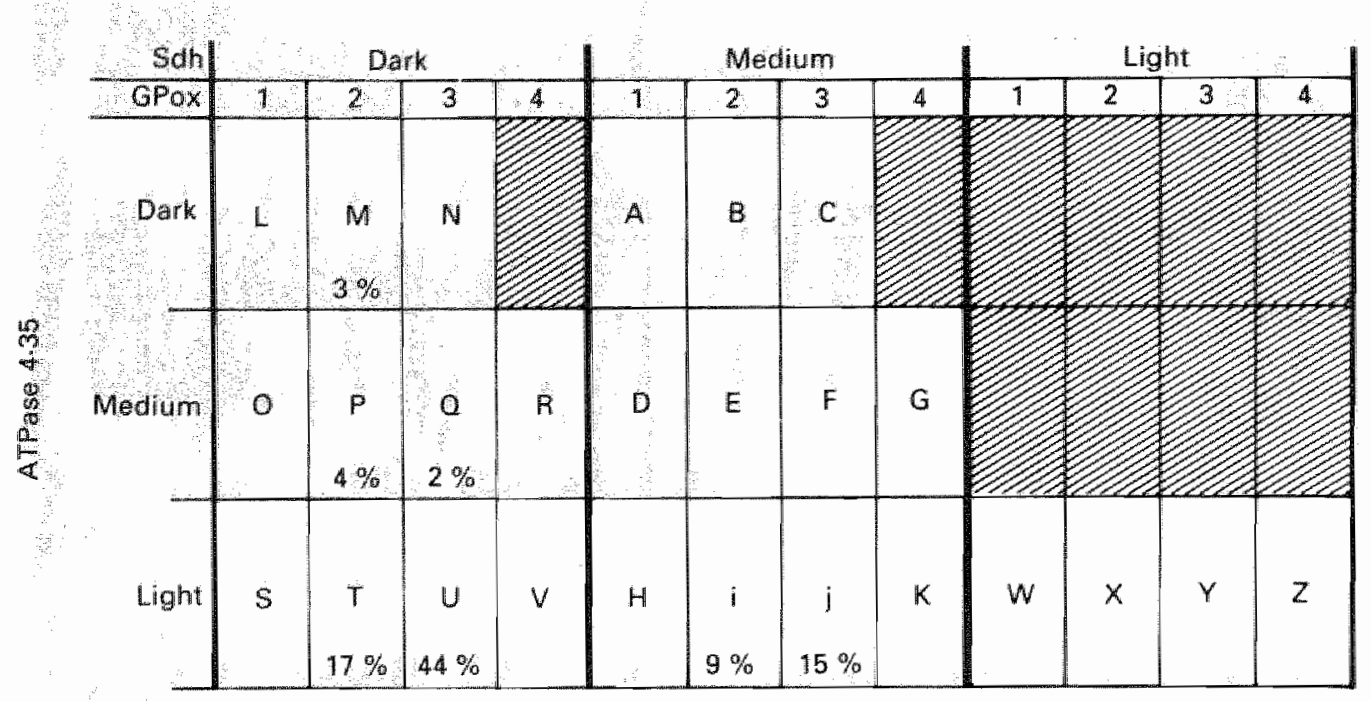

Fig. 4.5. Combination scheme of histochemical reactions (ATPase $\mathrm{pH} 4.35, \mathrm{SDH}$ and GPox) indicating the different fibre types (Wirtz, Loermans, Peer \& Reintjes, 1983) A C, slow fibres, equivalent to slow oxidative fibres* (SO); D-G; transitional fibres; $L-N$ and $O-R$, rare fibres; S-V, fast red fibres, of these $U$ and $V$ equivalent to fast oxidative glycolytic* (FOG); H-K, intermediate fibres; W-Z, fast white fibre, of these $\mathrm{Y}$ and $\mathrm{Z}$ equivalent to fast glycolytic fibre ${ }^{*}$ (FG). The shaded blocks are non-occurring combinations. (* According to Peter et al., 1972). The mean percentages of the occurring fibres of three stapedius muscles of the rat are indicated in the figure. NB: Fibres that occured in a percentage less than $2 \%$ are not presented in the figure. 


\subsubsection{Immunohistochemistry}

Figure 4.6 shows serial cross-sections stained with the various antiheavy chain myosin antibodies.

With the anti-slow antibody all fibres stained above the background level and a range of staining intensities can be distinguished (Fig. 4.6g, h). Of all fibres, $33 \%$ showed a strong reaction when compared to reference sections of rat hindlimb muscles, and therefore those fibres were slow heavy chain myosin-positive. When compared with the ATPase ( $\mathrm{pH} \mathrm{4.35)}$ all the dark fibres in the ATPase staining (slow fibres) also appeared to react strongly with the anti-slow antibody (Fig. $4.6 \mathrm{i}, \mathrm{j}$ ). However, not all fibres that reacted strongly with the anti-slow antibody showed a strong reaction in the ATPase staining.

Many of the fibres that stained intensively with the anti-slow antibody, also stained with the anti-neonatal antibody (Fig. 4,6a, b). $28 \%$ of the fibres were found to react positively with this antibody. However, not all of these neonatal myosin-positive fibres were positive for anti-slow and vice versa.

With the anti-slow plus IIA antibody, all fibres reacted positively. The majority of the fibres showed a moderate staining intensity (63\%), while $37 \%$ stained strongly (Fig. 4.6e, f). Most of the latter fibres also reacted strongly with the anti-slow antibody.

With the anti-IIB antibody all of the fibres showed a weak reaction as compared to the background level.

Staining with the anti-embryonal and the anti-slow tonic antibody did not reveal any positive fibres. However, results with the latter are not fully conclusive since reference stainings of a tensor tympani muscle of a dog, which is believed to contain slow-tonic fibres (Mascarello et al., 1982), did not show any positive fibres either. 

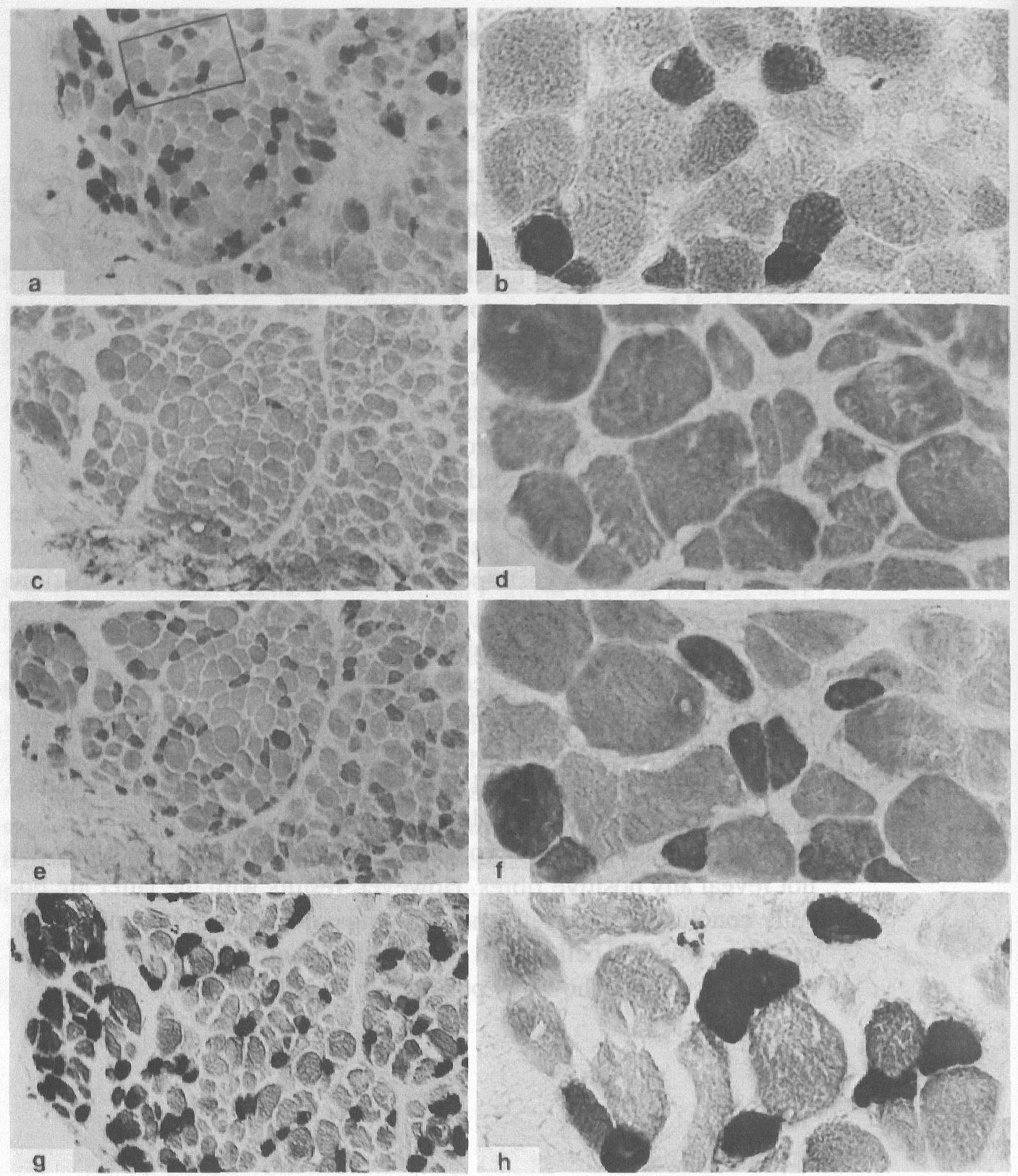

Fig. 4.6 (a-j). Anti-heavy chain myosin stainings of serial-cross section of the stapedius muscle of the rat. On the left: serial sections of, respectively, anti-neonatal (a), anti-IIb (c), anti-slow plus IIA (e), anti-slow (g). On the right (b, d, f, h): details of the corresponding sections of the area indicated in (a). (i-j) Detail of ATPase staining $(\mathrm{pH} 4.35)$ (i) and corresponding area stained with the anti-slow antibody (j). See text. (a, c, e, g) x 109; (b, d, f, h, i, j) x 462 . 

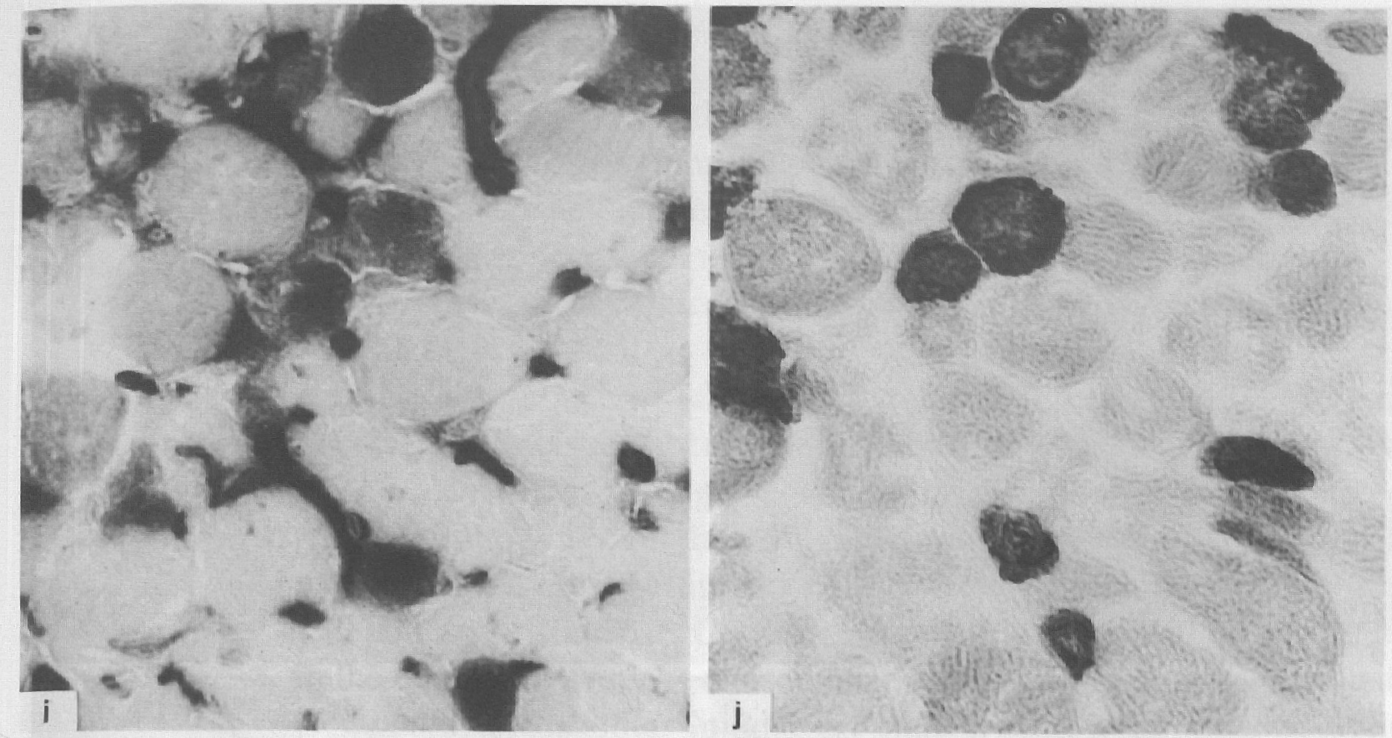

\subsubsection{Electron microscopy}

Ultrastructurally the stapedius muscle fibres showed a rather atypical aspect compared to normal skeletal muscle. Several fibres were composed of relatively small bundles of myofilaments as are often found in slow fibres of normal skeletal muscle. Apart from the irregular course of the fibres the mitochondria had an atypical arrangement. Many fibres demonstrated longitudinal clusters of large mitochondria preferentially localized between bundles of myofilaments. Others showed a less irregular arrangement of mitochondria. However, in general the regular localization of mitochondria next to the I-band as is often present in normal skeletal muscles was not found. Furthermore, aggregations of mitochondria were observed in a subsarcolemmal position and often close to capillaries (fig. 4.7b).

Satellite cells were encountered and an extensive nerve and blood supply was present (Fig. 4.7a). The motor endplates showed extensive branched foldings of the post-synaptic membrane resulting in a labyrinthine pattern. The presynaptic area contained many vesicles and mitochondria indicative for a distinct neuromuscular activity (Fig. $4.7 c-d)$. 

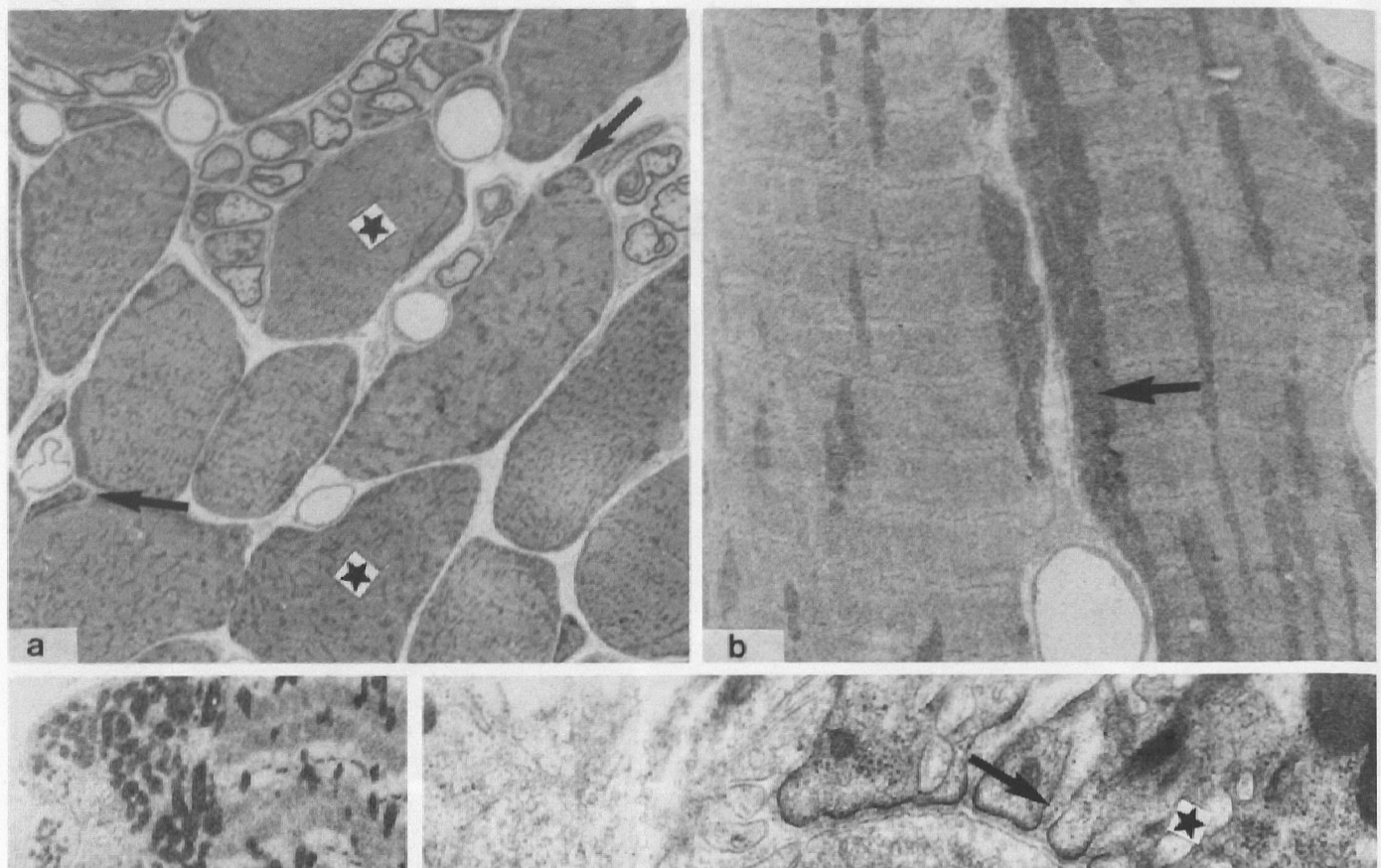

$\therefore 125$
(2) 35.4

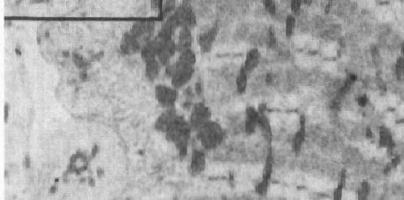

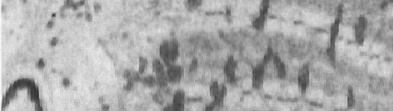
3. $x+2$

- s.

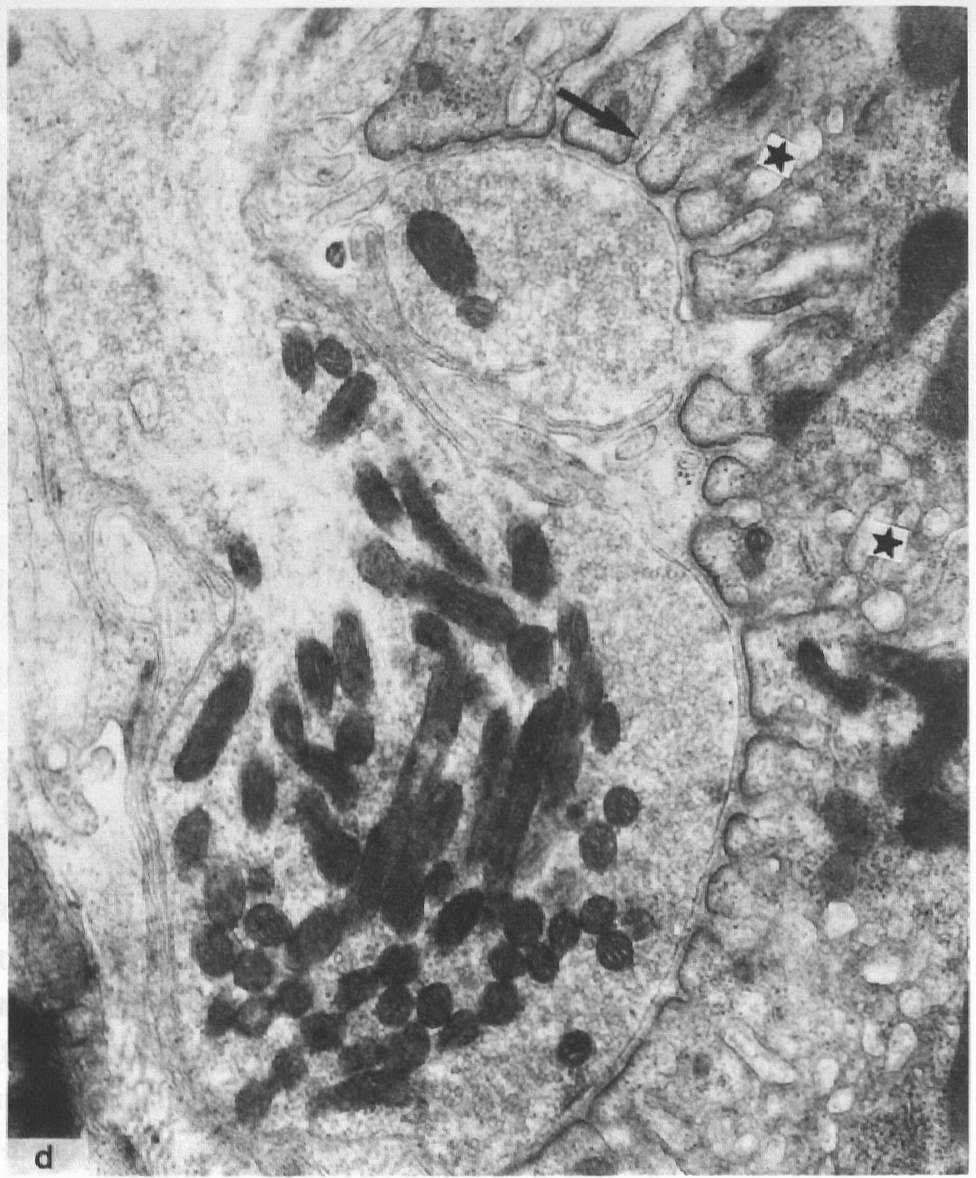




\subsection{Discussion}

The stapedius muscle of the rat is a very small muscle. Not much was known about its gross morphological structure. The small size and the localization of the muscle in the bony wall of the bulla render dissection of the whole muscle in vivo difficult.

The various morphological features may indicate interesting physiological aspects, such as the contraction pattern, contraction force, contraction velocity, and fatiguability. As far as the contraction pattern is concerned, the reconstruction, using serial cross sections, showed that the muscle is circumpennate and the insertion tendon is situated paracentrally. Based on this structural arangement, the range of action on contraction must be limited, resulting in a contraction pattern that will be nearly isometric. Considering the fragile position of the stapes in the oval window niche an isometric contraction pattern is indicated. Compared to the other middle ear muscle, the tensor tympani, the contraction force of the stapedius muscle is probably small. The muscle consists of approximately 300 muscle fibres, whereas the tensor tympani has approximately 1000 fibres (Berge \& Wirtz, 1989). However, the mean cross-sectional area of the fibres of the stapedius muscle is larger than that of the tensor tympani muscle fibres, respectively $782 \mu \mathrm{m}^{2}$ and $259 \mu \mathrm{m}^{2}$ (Berge \& Wirtz, 1989). This tendency is also found in sheep, cats, dogs, rabbits, horses, cows and pigs (Vegetti et al., 1982). The difference in fibre area between the two muscles is smaller when calculating the stapedius muscle fibre area from the smallest diameter: $490 \mu \mathrm{m}^{2}\left(\pi \mathrm{r}^{2}=3.14 \times(25: 2)^{2}\right)$. This may indicate bias in the measurements of the fibre area, possibly caused by measurements on partially obliquely cut muscle fibres.

Fig. 4.7 (a-d). Electron microscopy of the rat stapedius muscle.

(a) Transverse section. Note the irregular shape of fibres (asteriks) and extensive nerve supply. Arrows, satellite cells. (b) Longitudinal section. Note the longitudinal clusters of mitochondria between the bundles of myofilaments. Arrow, subsarcolemmal mitochondria. (c) Longitudinal section of a large motor endplate. (d) Detail of the area indicated in (c). Note the great number of presynaptic vesicles and mitochondria and the labyrinthine foldings of the post-synaptic membrane (arrow and asterisks). (a) $\times 1167$; (b) $\times 3247$; (c) $\times 3524$, and (d) $\times 18750$. 
Next to the number of fibres and the area of the fibres, the ultimate resulting contraction force also depends on the course of the fibres. The serial cross sections showed the fibres to run radially at the insertion site. This would reduce the ultimate contraction force. However, definite conclusions cannot be made, as deformation of the muscle on excision may alter the course of the fibres. To evaluate this, an in situ three dimensional reconstruction would be neccesary (see Chapter 2).

Submicroscopically, the structure of the muscle fibres is atypical. The muscle fibres were found to be irregularly shaped, and the bundels of myofilaments were often found te be small. Bundles of myofilaments that interconnect, as was found in the tensor tympani muscle of the rat (Berge \& Wirtz, 1989), were not observed. In summary, the morphological findings indicate a smaller maximal contraction force for the stapedius muscle than for the tensor tympani muscle. Indeed, electrophysiological studies in the cat and rabbit showed a smaller contraction force for the stapedius muscle (Teig, 1972). Despite this, the attenuation of sound transmission caused by contraction of the stapedius muscle is found to be larger (Møller, 1965; Teig, 1973). An explanation for this could be the larger moment developed on contraction of the stapedius muscle (Teig, 1973). Also as a result of its insertion onto the stapes, the stapedius muscle influences directly the sound transmission from middle ear to inner ear.

The enzyme histochemical findings indicate the muscle to be adapted for fast contraction as the majority of the fibres appeared to be fast twitch. Only $5 \%$ of the fibre population were classified as slow twitch. The ATPase reactions with different pre-incubation $\mathrm{pH}$ and the staining for GPox and SDH showed that the fast fibres are type IIA, i.e. fast oxidative glycolytic fibres. The slow twitch fibres, however, cannot be classified properly as the classical type I fibres, i.e. slow oxidative, since these fibres were revealed as slow oxidative glycolytic. The immunohistochemical staining also revealed atypical findings. Firstly, with the anti-slow antibody, $33 \%$ of the fibres reacted positively, in contrast to the $5 \%$ slow fibres with the ATPase stainings. Furthermore all fibres reacted positivelly with the anti-slow plus IIA antibody, all fibres reacted positively with the anti-IIB antibody and $28 \%$ of the fibres were found to be anti-neonatal positive. The latter myosin subtype is absent in adult skeletal muscle (Schiaffino et al., 1988). It may be considered that cross reactions cause all these findings. How- 
ever, in the same series of incubations, stainings of cross-sections of the soleus muscle and EDL muscle of the rat, with a well known enzyme histochemical and immunohistochemical fibre type composition (Zuurveld et al., 1985; Reggiani, in preparation), reacted as predicted. Therefore it is most likely that in the stapedius muscle of the rat different, but fully differentiated, i.e. heavy chain myosin types do occur in one fibre. As has been previously suggested (Berge \& Wirtz, 1989) the cell-biological explanation of this could be that genes coding for the various myosin heavy chains continue to be activated, and possibly do so in different nuclei that are contained in the syncytium. Concerning the fatiguability of the muscle, SDH and GPox stainings showed the muscle to have a relatively large aerobic and anaerobic capacity. The patchy appearance of the fibres in these stainings is caused by the mitochondria being clustered. A relatively intensive blood and nerve supply, the latter combined with large endplates containing many presynaptic vesicles suggests that the muscle has a relatively high resistance to fatigue and an active neuromuscular junction.

On reviewing the overall morphological data it appears that the stapedius muscle of the rat has certain atypical morphological characteristics of which the biological significance is not yet completely understood. However, it becomes clear that the smallest skeletal muscle has properties which possibly bear important physiological consequences: the muscle is presumed to have an almost pure isometric contraction pattern, it is able to contract rapidly and with a relatively great endurance. As comparable findings were made in the tensor tympani muscle, it emerges that the middle ear muscles of the rat are adapted for active functioning over longer periods of time. Both are important properties in the concept of the middle ear muscles being protective against loud impact noise over longer periods of time. Electrophysiological studies are in progress to evaluate this concept (see Chapter 6). 


\section{Acknowledgements}

We thank Prof. S. Schiaffino and Dr. F. Mascarello for kindly providing the myosin antibodies, A. v. Geest and H.M.Th. Loermans for the technical assistance, $H$. Rensema for drawing Figure 4.1, and P. Jap from the department of Cell-Biology of the University of Nijmegen, for his contribution to the results and interpretation of the electron microscopy.

This study was supported by the Heinsius-Houbolt Foundation. 


\subsection{References}

Berge, H. van den \& Wirtz, P. (1989). Detailed morphology of the tersor tympani muscle of the rat. An integrated lightmicroscopical, morphometrical, histochemical, immunohistochemical and electron microscopical study in relation to function. Journal of Anatomy 164, 215-228.

Borg, E., Counter, S.A. \& Rösler, G. (1984). Theories about midd ear muscle function. In: The acoustic reflex; Basic principles and clinical applications (ed. S. Silman). Orlando, Florida: Academic Press.

Djupestand, G. (1964). Middle-ear muscle retlexes elicited by acoustic and nonacoustic stimulation. Acta Otolaryngologica, Suppl. 188, 287-292.

Jong, F.I.C.R.S. de, Kingma, H., Wirtz, P., Berge, H. van den \& Marres, E.H.M.A. (1988). Indications of a differentiated regulation of sound transmis sion by the middle ear muscles of the rat. Journal of Otology 9, 70-75.

Kobayashi, M. (1956). The comparative anatomical study of the stapedial muscles of the various kinds of mammalian animals. Hirochima Journal of Medical Science 5, 63-84.

Mascarello, F., Carpenè, E., Vegetti, A., Rowlerson, A. \& Jenny, E. (1982). Tensor tympani muscle of cat and dog contains IIM and slow-tonic fibres: an unusual combination of fibre types. Journal of Muscle Research and Cell Motility 3, 363-374.

Mascarello, F., Vegetti, A., Carpenè, E. \& Rowlerson, A. (1983). An immunohistochemical study of the middle ear muscles of some carnivores and primates, with special reference to the IIM and slow-tonic fibre types. Journal of Anatomy $137,1,95-108$.

Møller, A.R. (1965). An experimental study of the acoustic impedance of the middle ear and its transmission proporties. Acta Otolaryngologica 60, 129-149.

Peter, P. B., Barnard, R.J., Edgerton, V.R., Gillespie, C.A. \& Stempel, K.E. (1972). Metabolic profiles of three fiber types of skeletal muscle in guinea pigs and rabbits. Biochemistry $11,2627-2633$.

Schiaffino, S., Gorza, L., Pitton, G., Saggin, L., Ausoni., S., Sartore, S. \& Lomo, T. (1988). Embryonic and neonatal myosin heavy chain in denervated and paralyzed rat skeletal muscle. Developmental Biology $127,1-11$.

Teig, E. (1972). Force and contraction velocity of the middle ear muscles in the cat and rabbit. Acta Physiologica Scandinavia 84, 1-10.

Teig, E. (1973). Differential effect of graded contraction of middle ear muscles on the sound transmission of the ear. Acta Physiologica Scandinavica, 88, 382 391. 
Vegeth, A., Mascarel1o, F. \& Carpene, E. (1982). A comparative histochemical study of fibre types in middle ear muscles. Journal of Anatomy 135,2, $333-352$.

Wirtz, P., Loemans, H.M.Th., Peer, P.G.M. \& Reintjes, A.G.M. (1983). Postratal growth and differentiation of muscle fibres in the mouse. I. A histochemical and morphometrical investigation of normal muscle. Journal of Anatomy 137, $109-126$.

Zuurveld, J.G.E.M., Wirtz, P., Loermans, H.M.Th. \& Veerkamp, J.H. (1985). Postnatal growth and differentiation in three hindlimb muscles of the rat. Cell Tissue Research $241,183-192$. 


\section{CHAPTER 5}

\section{The innervation of the middle ear muscles of the rat}

\section{Summary}

The innervation of the tensor tympani muscle and the stapedius muscle in the rat was studied. This was done by acetylcholinesterase in toto staining of the tympanic bullae and of muscles dissected seperately, acetylcholinesterase staining of serial cross sections of the muscles, silver impregnation of serial sections of complete tympanic bullae, serial semithin sections stained according to Laczko and Levai and electron microscopy of both muscles. The gross innervation of the muscles and the relation to other nerves in the bulla are described. It is shown that both muscles are innervated by very thin nerve fibres which form a well organized elaborate network in the muscles, with wery short branches that connect the motor endplates. Electron microscopically there are indications that the endplates in the stapedius muscle seem to enabie faster activation of the muscle fibres than those of tensor tympani muscle. No morphological evidence for any sensory irnervation of the muscles could be detected in the muscles themselves, in the connective tissue related to the muscles, or in the contents of the bulla tympanica. It is postulated that the afferent input of the acoustic reflex is sound and that sensory information from the muscles themselves or from other structures in the tympanic bulla does not contribute to the reflex.

$H$. van den Berge and J.C. van der Wal.

Accepted for publication in the Journal of Anatomy. 


\subsection{Introduction}

The middle ear muscles, the stapedius and tensor tympani muscle, are known to react reflexively to sufficiently loud acoustic stimuli. In this way they are thought to protect the inner ear from overstimulation (Borg, Counter \& Rösler, 1984). In the past, research into the function of the acoustic reflex was characterized by studies of morphological and electrophysiological aspects in various animal species. This has shown important interspecies differences in both structure and function which hinders the integration of various physiological and morphological characteristics. We therefore set out to perform an integrated study of structure and function in one animal species, i.e. the rat. Detailed morphological features of the muscles and electrophysiological characteristics as latency, rise time and effect of the reflex on sound transmission in this species have been presented before (Berge \& Wirtz, 1989a; Berge \& Wirtz, 1989b; Berge, Kingma, Kluge \& Marres, 1989). This has shown several atypical morphological findings in these muscles. Furthermore, enzyme histochemical staining indicated that the muscle fibres were able to contract fast and that they have a high resistance to fatigue. In addition, the acoustic reflex in the rat showed to have a short latency and rise time. These findings raise questions about the morphological basis of the neuromotor control of the muscles. Recent studies in this field are scarce; however there has evidence been presented that the sensory innervation of the muscles themselves is quite restricted (Blevins, 1963, 1964). Putatively, the afferent side of the middle ear muscle reflex could originate from other structures in the bulla tympanica. In man, Pacinian corpuscules have been found in the middle ear (Gussen, 1970). Furthermore, recent studies of skeletal muscles have provided evidence that connective tissue structures around the muscles contain free or corpuscular sensory nerve endings (Wal, 1988). Therefore, it seemed plausible to study along with the nervous substrate of the muscles themselves, the bulla tympanica for possible sensory input for the middle ear muscle reflex. 


\subsection{Materials and methods}

In this study thirteen twelve weeks old male Lewis rats were used. Three rats were fixed by means of perfusion via the heart with Bouin's fixative $\left(4^{\circ} \mathrm{C}\right)$ under Narcovet ${ }^{2}$ anaesthesia. The six tympanic bullae were removed and processed for decalcification, dehydration and paraffin embedding. The specimens were orientated in different directions in order to obtain sections of the middle ear muscles in two directions perpendicular to each other. Serial sections of $5 \mu \mathrm{m}$ were made and every fifth section was collected for silver impregnation according to Spaethe (1984). In these sections several aspects were examined. First of all, nervous tissue elements in the tensor tympani and the stapedius muscles were studied. Secondly, all the sections were screened for signs of sensory innervation outside the muscles, with special attention to the surrounding connective tissue, mucosa in the bulla, and connective tissue around the chain of ossicles. Finally, in two bullae from different animals the diameters of the nerve fibres of the nerves innervating the tensor tympani and stapedius muscles were measured, to gain insight into the origin of the fibres. For this purpose measurements were done on cross sections by means of ocular measurements of the smallest diameter at a magnification of $x 400$.

To study the gross innervation of the bulla and muscles in situ, two bullae of two rats were removed following adequate fixation and processed for acetycholinesterase in toto staining according to Baljet \& Drukker (1975). For this purpose each bulla was cut by a diamond saw into five slices, each about $1.5 \mathrm{~mm}$ thick. In this way nerves in the middle ear could be traced with the binocular microscope to clarify topography and anatomical relations.

For the staining of motor endplates, four stapedius and four tensor tympani muscles were dissected from two rats during Narcovet ${ }^{(3)}$ anaesthesia. The muscles were snap frozen in liquid nitrogen cooled freon. Serial cryo-sections of $10 \mu \mathrm{m}$ were made and acetylcholinesterase staining (Holt \& Withers, 1952) followed by Sirius red staining (Sweat, Puchtler \& Rosenthal, 1964, modified by Lubbers, Loermans \& Wirtz, 1988) was applied. In addition, indoxyl-esterase in toto stainings were made (Holt \& Withers, 1952) of two stapedius and two tensor tympani muscles. For this purpose the muscles were dissected from two rats that were fixed with $10 \%$ formaline by means of intracardially applied perfusion fixation under Narcovet anaesthesia. 
In order to find clues to the sensory innervation in the muscles themselves, two stapedius and two tensor tympani muscles were dissected from two rats following perfusion fixation via the heart with $6 \%$ glutaraldehyde $\left(4^{\circ} \mathrm{C}\right)$ during Narcovet anaesthesia. The muscles were embedded in Epon and serial sections of $1 \mu \mathrm{m}$ were made. All sections were stained according to Laczko \& Levai (1975) and searched for signs of sensory innervation.

For electron microscopy of the motor endplates, four tensor tympani and four stapedius muscles were dissected from two rats. Thin sections were double contrasted with uranyl acetate and lead citrate and examined in a Philips electron microscope EM 300.

\subsection{Results}

\subsubsection{Gross innervation}

The tensor tympani nerve enters the wall of the tympanic bulla at about two millimeters dorsal to the bullar orifice of the Eustachian tube. As it ascends along the wall of the bulla, the nerve divides into five very small branches at about $1.5 \mathrm{~mm}$ before reaching the midportion of the belly of the tensor tympani muscle. These branches enter the muscle on its dorsal aspect (Fig. 5.1a-c). The branches diverge to form a distinct band of nerve fibres in the muscle (Figs. 5.1d, 5.4b). The greater and lesser petrosal nerves are found in close relation to the muscle. The lesser petrosal nerve issues from the tympanic plexus on the promontory. It passes dorsally and descends in the canal for the

Fig. 5.1 (a-d). Nerve supply of the tensor tympani muscle in the rat; silver impregnations according to Spaethe (1984). (a) Transverse section through the tympanic bulla. Rectangle: tensor tympani muscle. (b) Transverse section through tensor tympani muscle; detail of the area indicated in (a). (c) Detail of the area indicated in (b); branch of tensor tympani nerve entering the muscle. (d) Section at a more caudal level of the tensor tympani muscle. Note the band-shaped configuration of nerve fibres in the muscle. C, cochlea; EM, external meatus; $M$, malleus; PM, major petrosal nerve; TC, tympanic cavity: TM, tympanic membrane; asterisks, branches of tensor tympani nerve. (a) $\times 14.5$; (b) $\times 107$; (c) $\times 345$; (d) $\times 107$. 

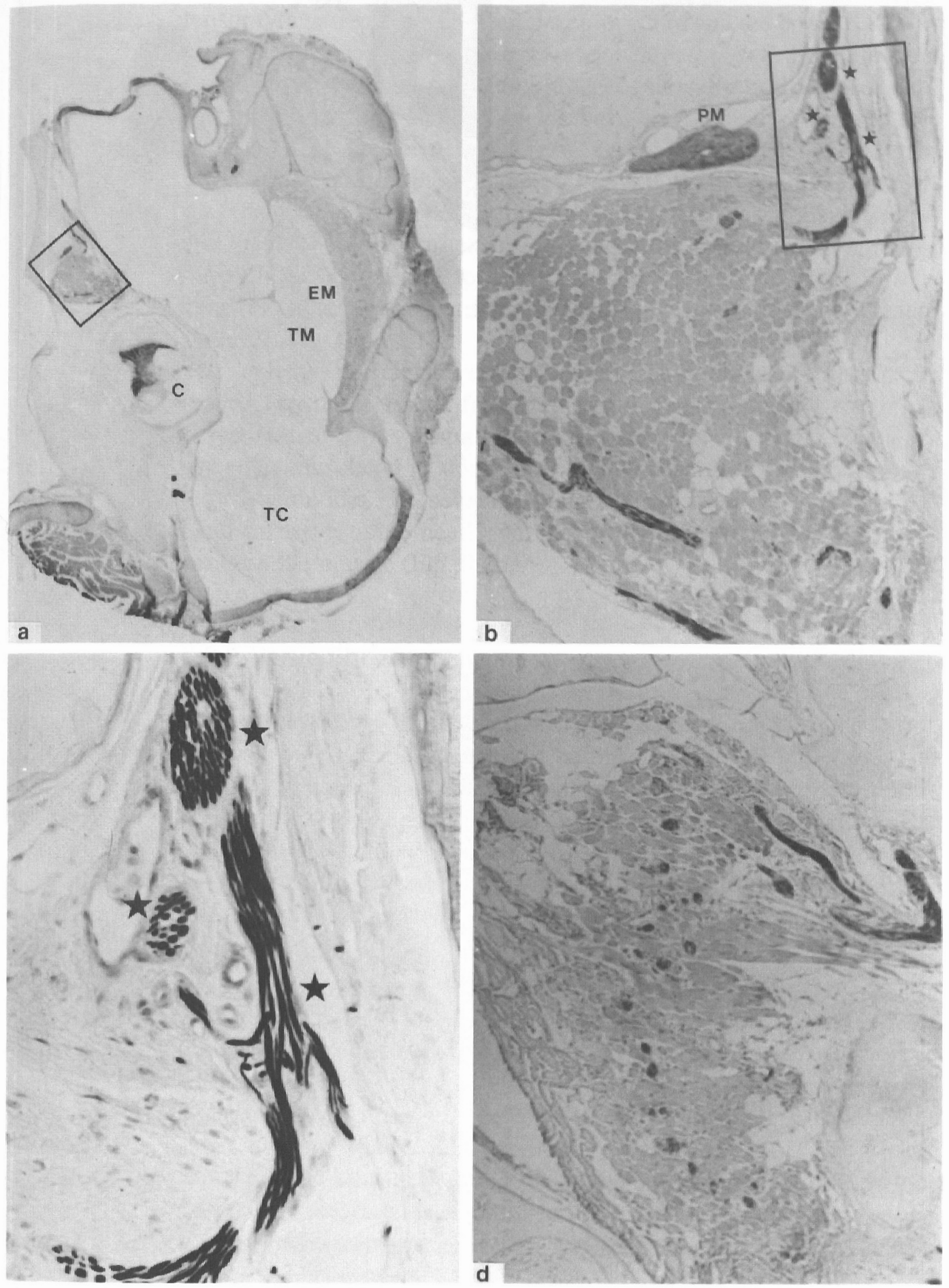

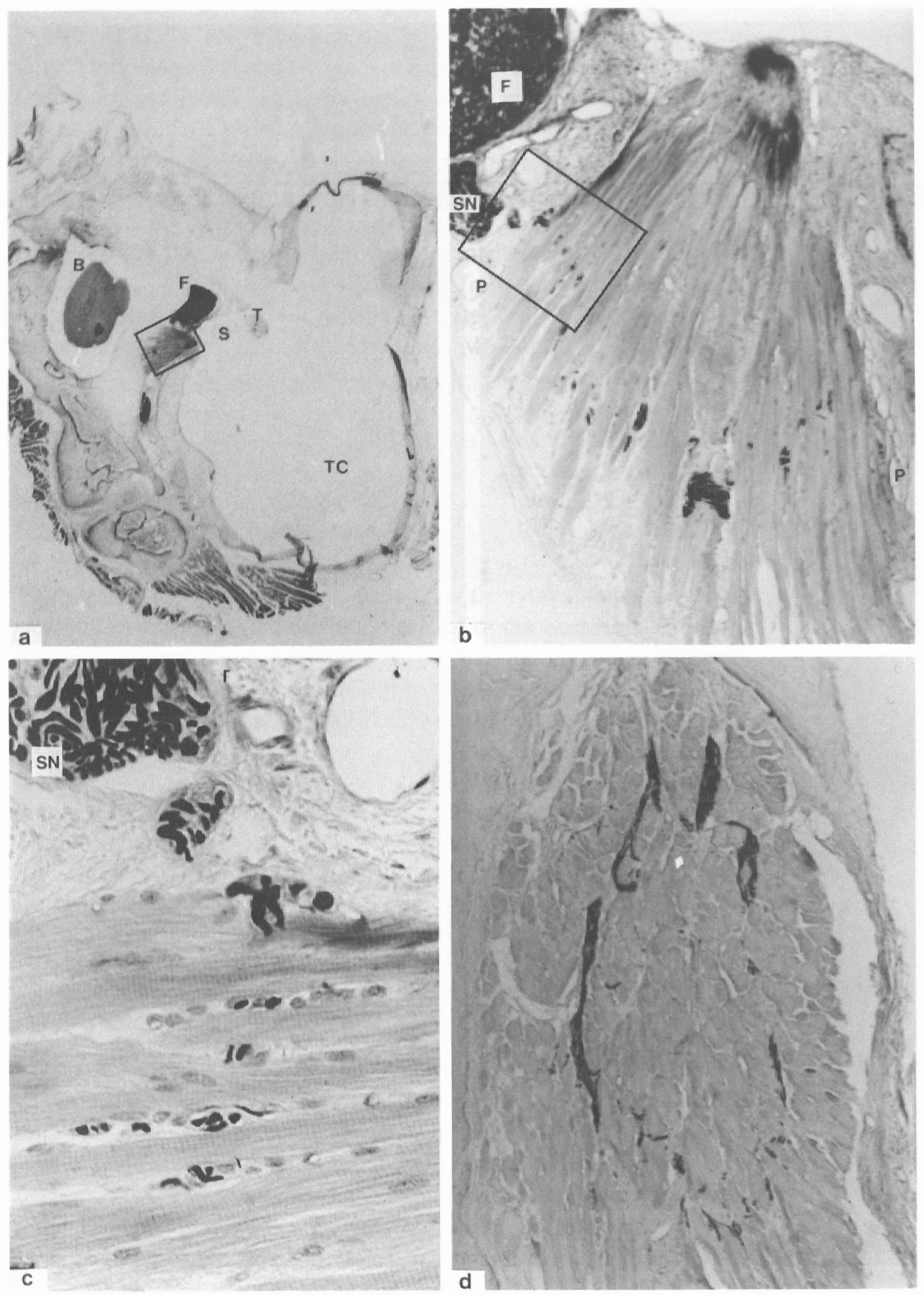
tensor tympani muscle between the epimysium and the bone. Half way along the muscle it leaves the osseous canal, passes below the branches of the tensor tympani nerve and proceeds dorsally to the tensor tympani nerve through the wall of the bulla in the direction of the otic ganglion. The greater petrosal nerve issues from the geniculate ganglion. It descends in the bullar wall in the direction of the crossing of the tensor tympani and lesser petrosal nerves, half way along the dorsal side of the belly of the tensor tympani muscle. At this site it passes medially to both nerves to descend in the medial wall of the osseus canal of the tensor tympani muscle, in close contact to the epimysium of the muscle (Fig. 5.1b).

The stapedius muscle proved to be innervated by a very short stapedial nerve. The nerve issues from the ventrocaudal aspect of the facial nerve. It then forms a small loop in a lateral direction and enters the stapedius muscle on its dorsal aspect (Fig. 5.2a-c). Inside the muscle, the nerve divides into several branches to constitute a hemi-ellipsoid band of nerve tissue nearly parallel to the bony wall of cavity that contains the muscle (Fig. 5.2b, d).

\subsubsection{Nerve fibre morphometry}

Figure 5.3 shows the diameters of the nerve fibres of the tensor tympani and stapedial nerves just before they enter the muscles. The figures represent the results of measurements of fibres in two tensor tympani and two stapedial nerves $(\mathrm{N}=75$ and $\mathrm{N}=77$ respectively). The diameters in both nerves were relatively small. The mean diameter for the fibres in the stapedial nerve was $2.3 \mu \mathrm{m}$ with a range of $1.3-5.0 \mu \mathrm{m}$ (S.D. 0.8). The tensor tympani nerve showed a mean fibre diameter of

Fig. 5.2 (a-d). Nerve supply of the stapedius muscle in the rat; silver impregnations according to Spaethe (1984). (a) Paramedian section through the tympanic bulla. Rectangle: stapedius muscle. (b) Detail of the area indicated in (a). (c) Detail of area indicated in (b); stapedial nerve entering stapedius muscle. (d) Section through stapedius muscle in a plane perpendicular to that of (c) through p-p. Note the oval band of nerve fibres in the muscle. $B$, brain tis sue; F, facial nerve; $S$, crura of stapes; $\mathrm{T}$, tendon of tensor tympani muscle; $\mathrm{SN}$, stapedial nerve; TC, tympani cavity. (a) $\mathrm{x}$ 10 ; (b) $\times 107$; (c) $\times 429$; (d) $\times 107$. 

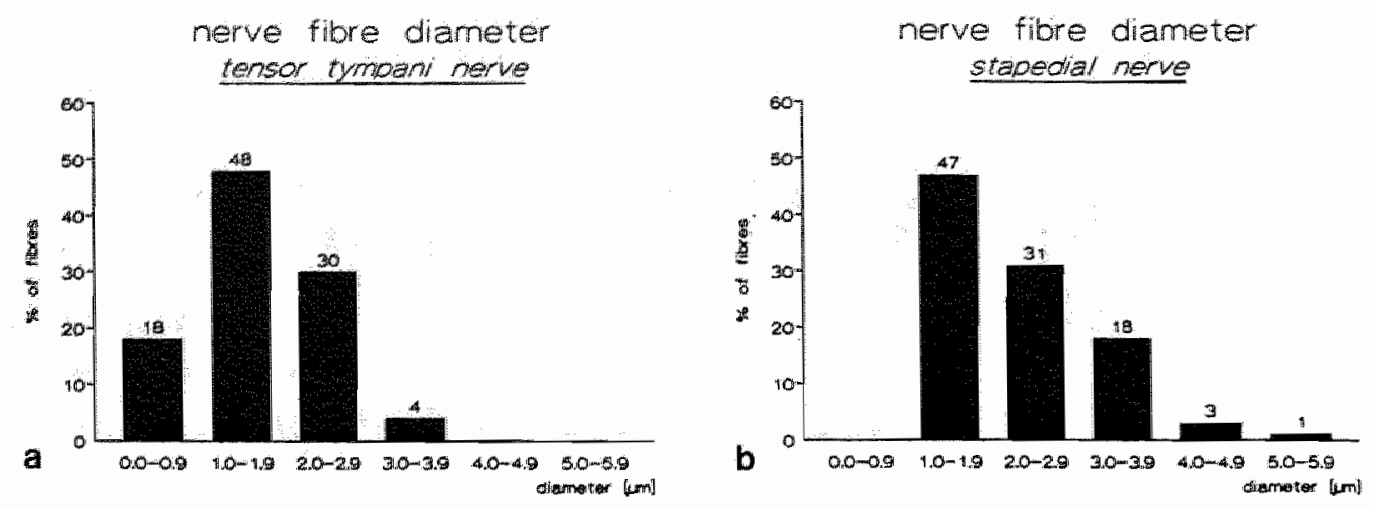

Fig. 5.3 (a,b). (a) Histogram of the diameter of the nerve fibres of a branch of the tensor tympani nerve of the rat just before entering into the tensor tympani muscle (mean $1.7 \mu \mathrm{m} ;$ S.D. 0.65) (b) Similar data, for the stapedial nerve just before its entrance into the stapedius muscle (mean $2.3 \mu \mathrm{m} ;$ S.D. 0.82)

$1.7 \mu \mathrm{m}$ with a range of $0.6-3.7 \mu \mathrm{m}$ (S.D. 0.65). No major differences between the two animals studied were observed. The distribution of the nerves fibre diameters was found to be unimodal (Fig. 5.3).

\subsubsection{Motor innervation}

In both muscles an elaborate network of nerve fibres was found which was organized to form a distinct pattern. In the tensor tympani a curved band of nerve fibres crosses the muscle obliquely in a plane orientated

Fig. 5.4 (a-d). Distribution of motor endplates in the stapedius muscle and tensor tympani muscle of the rat. (a) Acetylcholinesterase in toto staining of the tensor tympani muscle. Medial view. Note the endplates as small dots in the muscle. (b) Acetylcholinesterase staining of a transverse section of tensor tympani muscle in plane p-p indicated in (a). (c) In toto acetylcholinesterase staining of the stapedius muscle. Medial view. (d) Acetylcholinesterase staining of transverse section of stapedius muscle in plane p-p indicated in (c). $t$, tendon; asteriks, lesser petrosal nerve and part of tympanic plexus; white arrow heads, some motor endplates (staining blue-green). (a) $\times 28$; (b) $\times 77$; (c) $\times 28$; (d) $\times 98$. 
Innervation

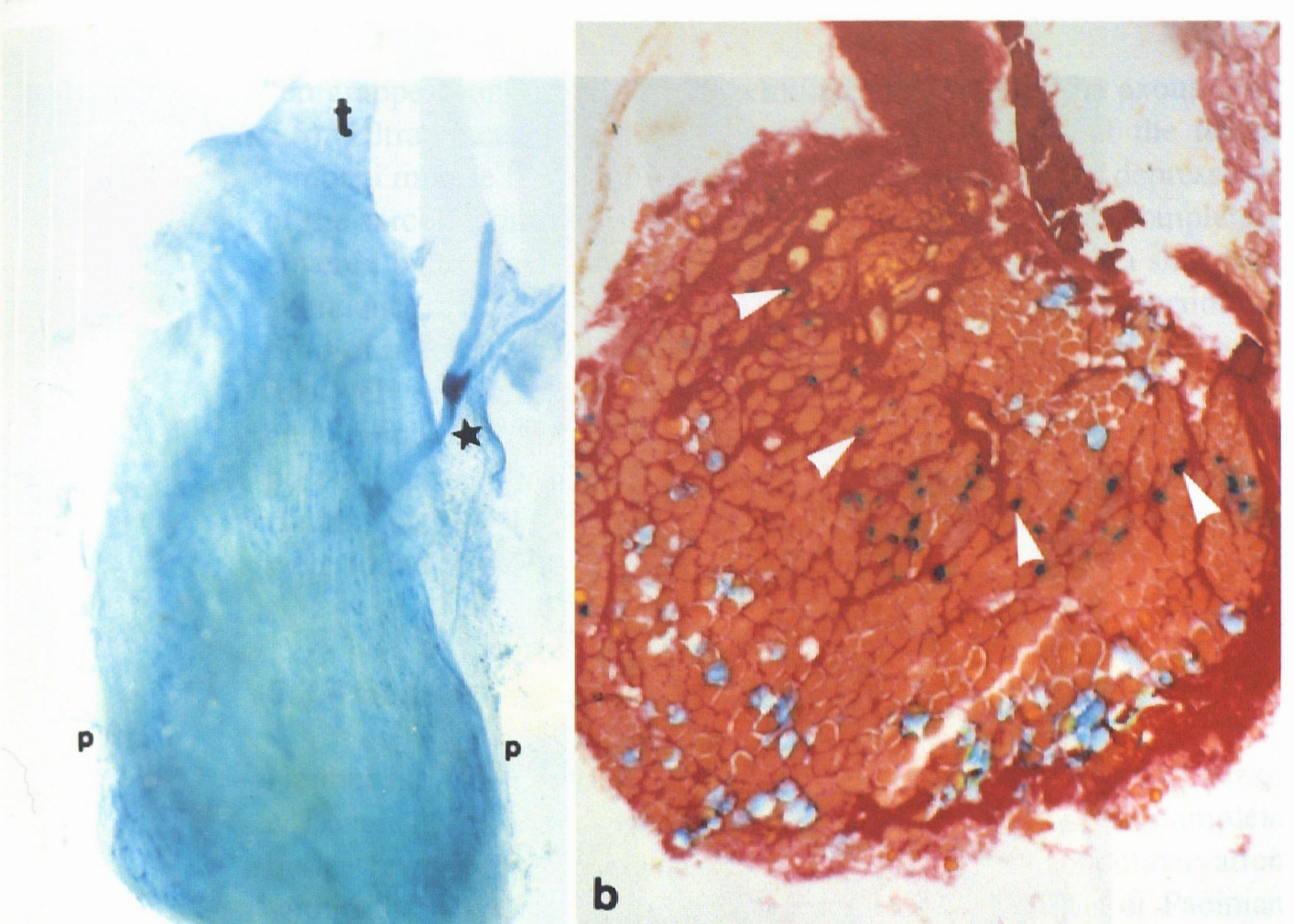

a

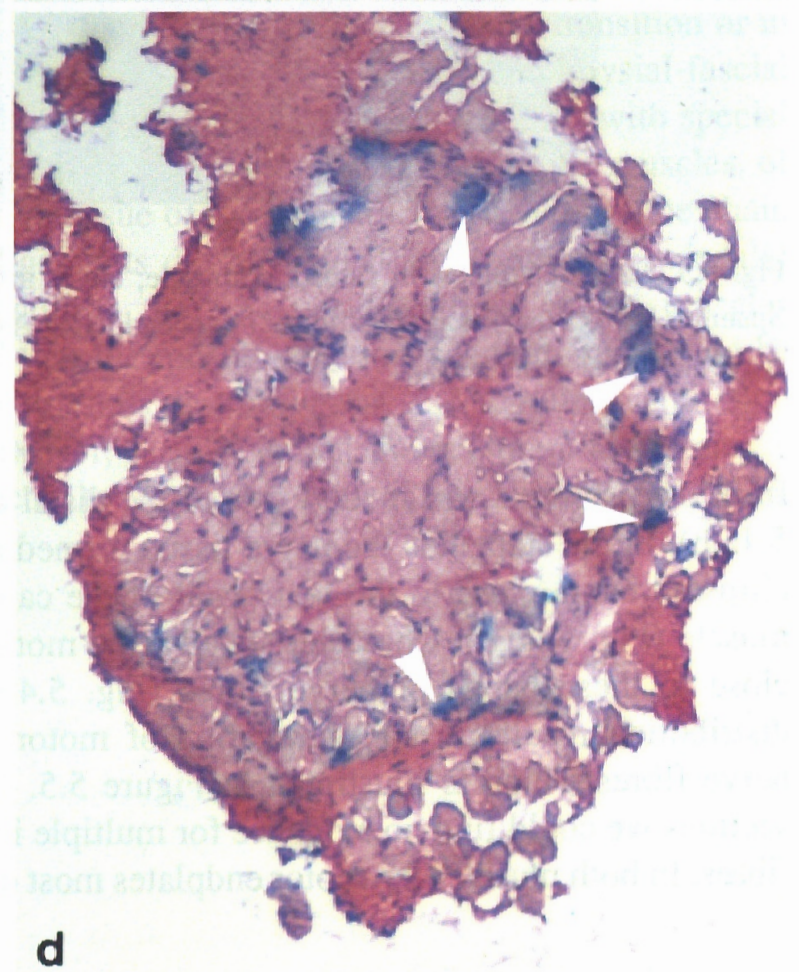

C

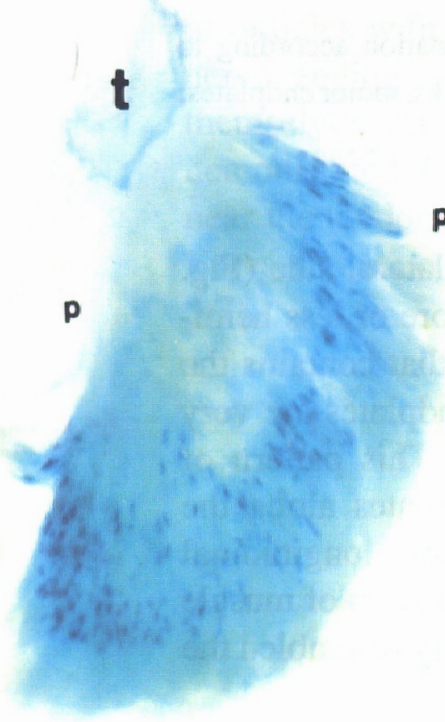




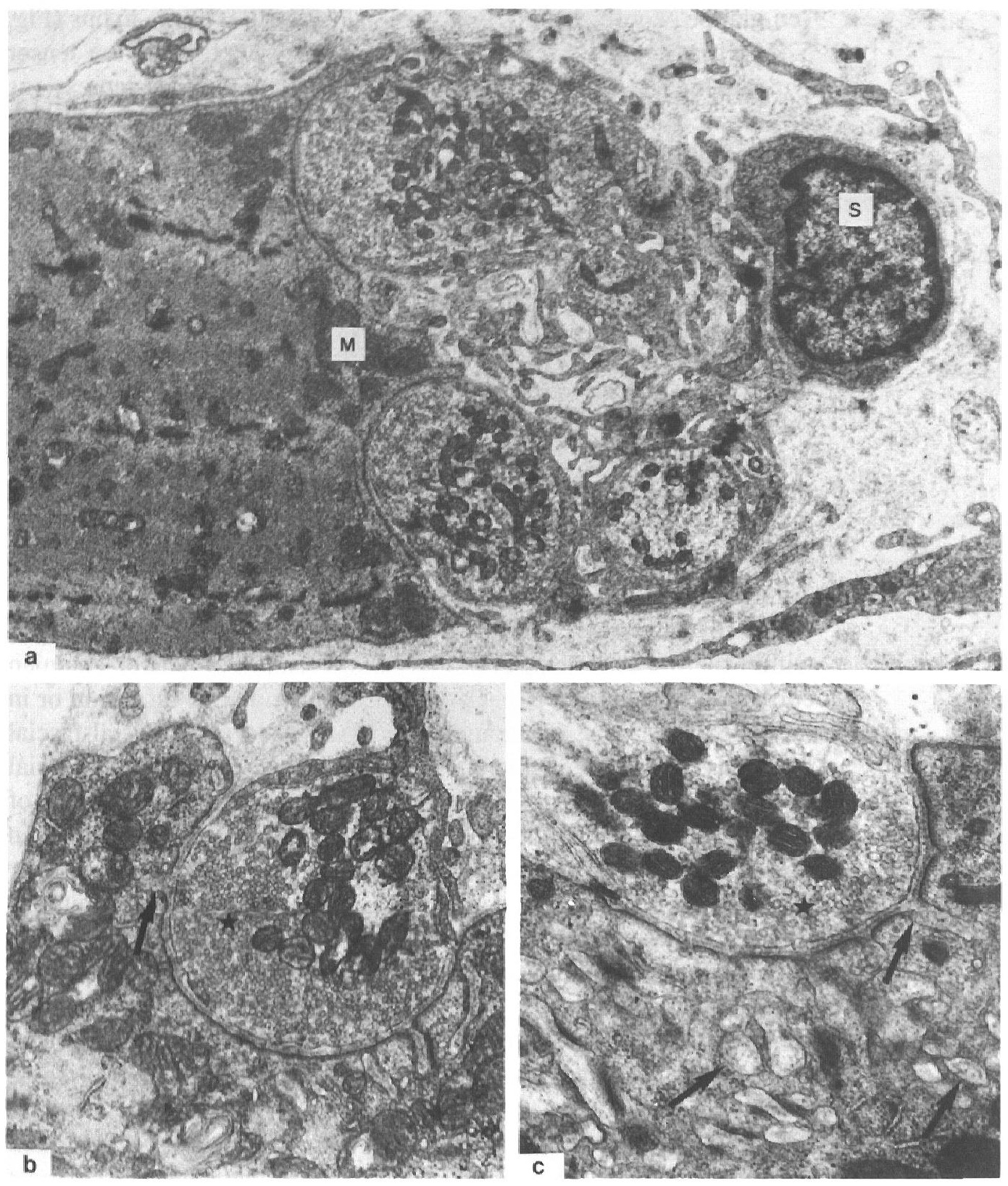



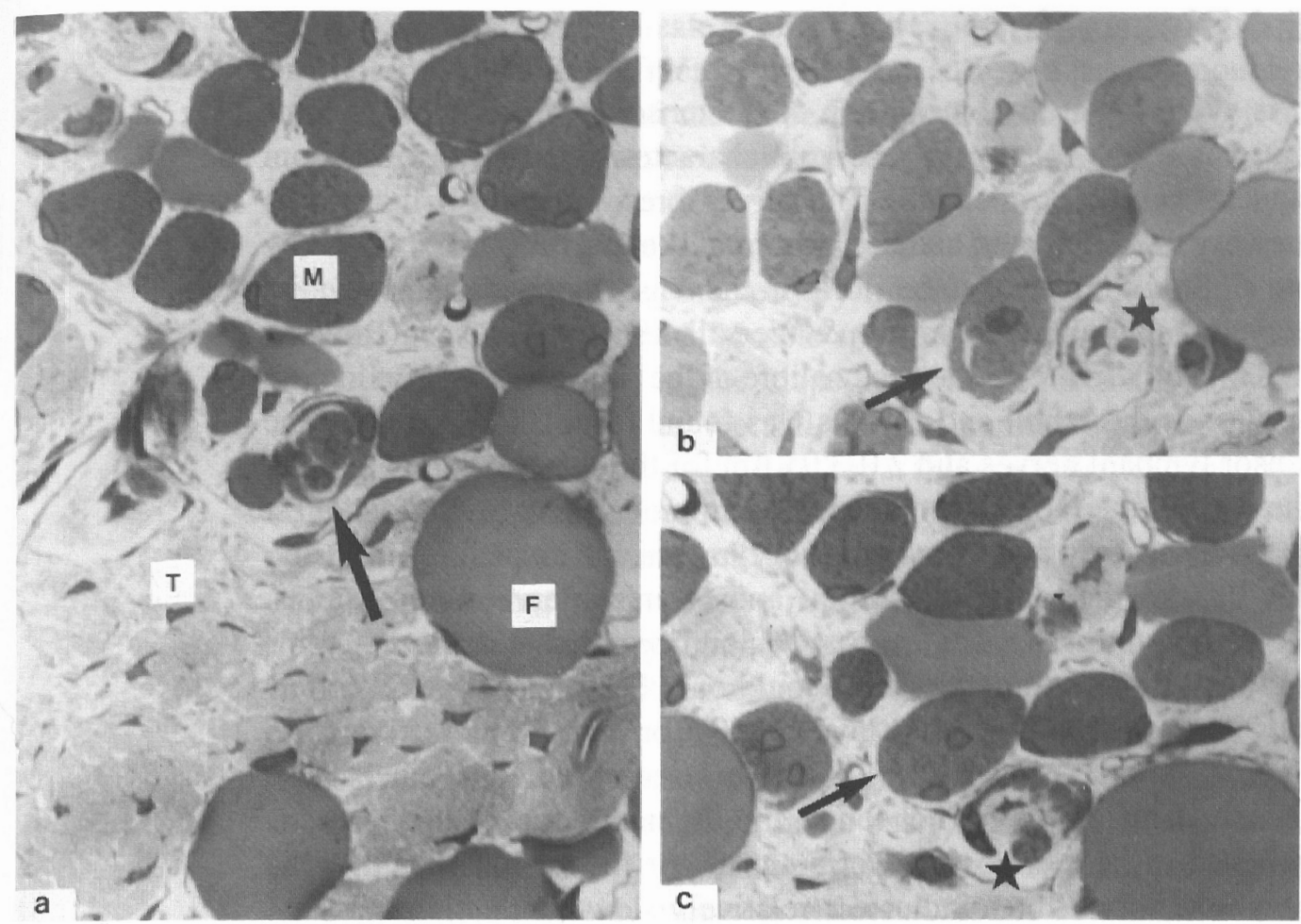

Fig. 5.7 (a-c). Musculo-tendinous transition area in tensor tympani of the rat. $1 \mu \mathrm{m}$ transverse sections stained according to Laczko and Levai (1975). (a) Arrow: a muscle fibre close to its insertion to the tendon resembling a muscle spindle. $M$, muscle fibre; F, fat cell; T, tendon. (b-c) Arrows: the same muscle fibre as seen in (a) (arrow) at successive levels; asterisks, another muscle fibre attaching to the tendon plate. (a-c) x 672 .

Fig. 5.6 (a-c). Electron microscopy of motor endplates of the middle ear muscles of the rat. (a) Motor endplate of the rat tensor tympani muscle. Note three terminations with many vesicles and mitochondria between 'S" (cell of Schwann) and 'M' (muscle fibre). (b) Detail of an endplate of the tensor tympani (c) Detail of an endplate of the stapedius muscle. Note the few and relatively simple foldings of the post-synaptic membrane in the tensor tympani (b) compared to the extensive elaborate foldings in the post synaptic membrane in the stapedius (c). Asterisks, pre-synaptic area; arrows, foldings in post-synaptic membrane. (a) x 7560; (b,c) x. 23000 . 


\subsection{Discussion}

It is evident that the innervation of the tensor tympani and stapedius muscles in the rat presents several characteristics that deviate from skeletal muscle at other sites. The nerve fibres supplying both muscles are very thin compared to those in normal skeletal muscle nerves. They are slightly thinner than the fibres in the tensor tympani and stapedial nerves of the rabbit (Malmfors \& Wersäll, 1960a, b) and cat (Blevins, $1963,1964)$. In the rat the peak calibre of the fibres was $1-2 \mu \mathrm{m}$ in both nerves; in the rabbit and cat this was found to be $2.0-3.0 \mu \mathrm{m}$ for the tensor tympani nerves and $2.0-3.95 \mu \mathrm{m}$ for the stapedial nerves. As in the cat and the rabbit the nerves were unimodal. The findings suggest that the nerve fibres of the rat tensor tympani and stapedius muscle do not fit into the classical afferent and efferent nerve fibre systems. According to these schemes, based upon fibre diameter, the stapedius and tensor tympani nerve fibres could only belong to Type III (afferents of Pacini corpuscles, Lloyd (1943)) or to $\gamma$ fibres (efferents to muscle spindles, Leksell, (1945)). This seems unlikely since these sensory structures were not found and the major part of the nerves is believed to be composed of efferent motor fibres. Functionally, the very thin nerve fibres indicate a relatively slow conduction velocity. However, the implication of this finding for the latency of the reflex would not seem that important since the axons of both nerves are relatively short $(<1 \mathrm{~cm})$.

The motor innnervation of the muscles seems to be well organized. There is a well defined, elaborate pattern of nerve fibres in both muscles. The motor endplates are connected to the main nerves by very short branches and thus are confined to the bands of nerve fibres. Like Anderson (1975), we could not find evidence of multiply innervated muscle fibres in the rat. Such an innervation was found in the cat by Fernand \& Hess (1969) but could not be confirmed by Haugsten, Bendikson, Dahl \& Teig (1982). However, with our methods, multiple innervation was difficult to assess since the muscle fibres do not follow a straight course and therefore they could not always be followed along their total length in the longitudinal sections. Ultrastructurally, the post-synaptic area of the motor endplates of the stapedius was somewhat different from that of the tensor tympani The surface area of the post-synaptic membrane of the stapedius was much larger than that of the tensor tympani and its post-synaptic area contained more mito- 
chondria. This could indicate a faster activation of the muscle fibres and possibly a shorter refractory period, because of a larger amount of acetylcholine esterase, of the stapedius. Indeed, the latency of the stapedius has been shown to be shorter than that of the tensor tympani in various mammals (Wersäll, 1958)

No sensory innervation of the muscles was found. In the past; controversial findings regarding the sensory innervation of the middle ear muscles have been reported. Muscle spindles, or muscle spindle-like formations, were found in the stapedius muscle of man (Blevins, 1967), rabbit (Malmfors \& Wersäll, 1960b), guinea pig, cat and rat (Steinitz, 1907), but in the cat and in the rat this could not be confirmed (Blevins, 1964; Candiollo \& Guglielmone, 1969). In the tensor tympani, muscle spindles have only been described in man (Candiollo, 1965). Some other workers have mentioned free nerve endings as a possible source of sensory input from the muscles. Free nerve endings in contact with muscle fibres have been described in the tensor tympani of the guinea pig (Portmann, 1949), rabbit (Malmfors and Wersäll, 1960a), rat and hedgehog (Candiollo \& Guglielmone, 1969). In the stapedius these endings have been described in the rabbit (Malmfors \& Wersäll, 1960b). In the cat sensory innervation could not be demonstrated in either muscle (Blevins, 1963, 1964). In the rat, even in the serial $1 \mu \mathrm{m}$ sections, we could not find any evidence of sensory innervation, including free nerve endings, in either middle ear muscle. In the musculo-tendinous transition area configurations resembling muscle spindles were found, however, these proved to be muscle fibres attaching to the tendon when followed in the serial sections. This would need further (electron microscopical) study to determine more detailed characteristics. In addition, no sensory corpuscles in the bulla tympanica, including the chain of ossicles or in the tissues surrounding the muscles could be demonstrated.

In conclusion, the middle ear muscles of the rat appear to have a well organized motor innervation pattern but no morphological evidence for sensory innervation. This would suggest that the muscles act as motor end organs without the possibility of a neuromuscular feedback loop, in contrast to other skeletal muscles. Such a feedback system, extremely important for the regulation of posture, movements and muscle tone would not seem to be important in the acoustic middle ear muscle reflex. This reflex should protect the cochlea from overstimulation. The afferent input of the reflex is sound alone, and apparently 
afferent information from the muscles themselves does not seem important to fulfill this function. This would indicate an analogous situation for the middle ear muscles as that of the external ocular muscles and the muscles of mastication in some species, in which afferents are known to issue from for example the retina and periodontal nerves respectively (Brodal; 1975).

\section{Acknowledgements}

We thank A. van Geest for the skilfull technical assistance and Dr. P. Jap, from the department of Cell Biology and Histology, University of Nijmegen, for his contribution to the results and discussion of the electron microscopy. We thank Prof. dr. J. Drukker, from the department of Anatomy and Embryology, University of Maastricht, for his constructive comments on the manuscript.

This study was supported by the Heinsius-Houbolt Foundation. 


\subsection{References}

Anderson, S.D. (1975). Peripheral aspects of the physiology of the middle ear muscles. Symposia of the Zoological Society of London 37,69-95.

Baljet, B. \& Drukker, J. (1975). An achetylcholinesterase method for in toto staining of peripheral nerves. Stain Technology 50, 31-36.

Berge, H. van den \& Wirtz, P. (1989a). Detailed morphology of the tensor tympani muscle of the rat. An integrated light microscopical, morphometrical, histochemical, immunohistochemical and electron microscopical study in relation to function. Journal of Anatomy 164, 215-228.

Berge, H. van den \& Wirtz, P. (1989b). Detailed morphology of the stapedius muscle of the rat. An integrated light microscopical, morphometrical, histochemical, immunohistochemical and electron microscopical study in relation to function. Journal of Anatomy 166, 157-169.

Berge, H. van den, Kingma, H., Kluge, C. \& Marres, E.H.M.A. (1980). Electrom physiological aspects of the middle ear muscle reflex in the rat. Latency, rise time and effect on sound transmission. Submitted for publication.

Blevins, Ch.E. (1963). Innervation of the tensor tympani muscle of the cat. American Journal of Anatomy 113, 287-301.

Blevins, Ch. E. (1964). Studies on the innervation of the stapedius muscle of the cat. Anatomical Record 149, 157-172.

Blevins, Ch.E. (1967). Innervation patterns of the human stapedius muscle. Archives of Otolaryngology 86, 136-142.

Borg, E., Counter, S.A. \& Rösler, G. (1984). Theories about middle ear muscle function. In: The acoustic reflex; Basic principles and clinical applications (ed. S. Silman). Orlando, Florida: Academic Press.

Brodal, A. (1975). Neurological anatomy in relation to clinical medicine. Second edition. London: Oxford University press.

Candiollo, L. (1965). Ricerche anatomo-comparative sul muscolo tensore del timpano, con riferimento alla innervazione propriocettiva. Zeitschrift für Zellforschung 67, 34-56.

Candiollo, L. \& Guglielmone, R. (1969). Further observations concerning the proprioceptive innervation of the tensor tympani muscle. Anatomische Anzeiger 125, 161-165.

Fernand, V.S.V. \& Hess, A. (1969). The occurrence, structure and innervation of slow and twitch muscle fibres in the tensor tympani muscle of the cat. Journal of Physiology 200, 547-554.

Gussen, R. (1970). Pacinian corpuscles in the middle ear. Journal of Laryngology and Otology 84, 71-76. 
Haugsten, P., Bendikson, F.S., Dahl, H.A. \& Teig, E. (1982). The motor innervation pattern of the cat tensor tympani muscle as revealed by histochemical study of serial cross section. Acta Otolaryngologica 386, 291-295.

Holt, S.J. \& Withers, R.F. (1952). Cytochemical localization of esterases using indoxyl deriyates. Nature 170, 1012-1014.

Laczko, J. \& Levail, G. (1975). A simple differential staining method for semithin sections of ossifying cartilage and bone tissue embedded in epoxy resin. Mikroskopie 31, 1-4.

Leksell, L. (1945). The action potentials and excitatory effects of the small ventral root fibres to skeletal muscle. Acta Physiologica Scandinavia 10, Suppl. 31, $1-84$.

Lloyd, D.P.C. (1943). Neuron patterns controlling transmission of ipsilateral hindlimb reflexes in cat. Journal of Neurophysiology 6, 293-315.

Lubbers, L., Loermans, H.M.Th. \& Wirtz, P. (1988). Sirius rood kleuring voor vriescoupes: een modificatie volgens Lubbers. Histotechniek 6 (5), 99-100.

Malmfors, T. \& Wersall, J. (1960a). Innervation of the middle ear muscles in the rabbit with special reference to nerve calibres and motor units; I. Musculus tensor tympani. Acta Morphologica Neerlando-Scandinavica 2, 157-162.

Malmfors, T. \& Wersäll, J. (1960b). Innervation of the middle ear muscles in the rabbit with special reference to nerve calibres and motor units; II. Musculus Stapedius. Acta Morphologica Neerlando-Scandinavica 2, 163-169.

Portmann, M. (1949). Le muscle du marteau: son innervation. Revue de Laryngologie, Rhinologie, Otologie 70, 534-546.

Spaethe, A. (1984). Eine modification der Silber methode nach Richardson für die Axonfärbung in Parafinschnitten. Anatomische Anzeiger 78, 101-102.

Steinitz, W. (1907). Beitrage zur Anatomia Musculus stapedius. Archiv fuer Ohrenheilkunde 70, 45-50.

Sweat, F., Puchtler, H. \& Rosenthal, S.I. (1964). Sirius red F3BA as a stain for connective tissue. Archives of Pathology 78, 69-72.

Wal, J.C. van der. (1988). The organization of the substrate of proprioception in the elbow region of the rat. Thesis. University of Limburg, Maastricht, The Netherlands.

Werstill, R. (1958). The tympanic muscles and their reflexes. Acta Otolaryngologica, Suppl. 139, 1-112. 


\title{
CHAPTER 6
}

\section{Electrophysiological aspects of the middle ear muscle reflex in the rat}

\author{
Latency, rise time and effect on sound transmission.
}

\section{Summary}

The rise time, the latency and the influence of the acoustic reflex on sound transmission were investigated in the adult rat during ketamin anaesthesia. This was done by measurements of the cochlear microphonics (CM) and electromyographic (EMG) recordings of the reflex responses of the tensor tympani muscle. The acoustic reflex was elicited by contralateral acoustic stimuli of which the intensity and frequency were varied. Ipsilaterally, the effect on transmission was determined by estimating the change in amplitude of $\mathrm{CM}^{\text {"s }} \mathrm{s}$ of ipsinateral administered subliminal stimuli. It was shown that both the tensor tympani and the stapedius muscle contribute in the reflex. The latency as well as the rise time of the reflex determined by $\mathrm{CM}$ recordings showed to be short (minimal values. 11.6 and 6.6 msec respectively). The mean latency of the tensor tympani muscle reflex, measured by EMG, was about 7 msec. The attenuation of $0.25-8 \mathrm{kHz}$ tone bursts of $115 \mathrm{dBSPL}$ is limited to a mean maximum of $15 \mathrm{dBSPL}$. A $1 \mathrm{kHz}$ tone burst was shown to be attenuated the most. The tones above $2 \mathrm{kHz}$ appeared to be the best elicitor of the middle ear muscle reflex. Relatively large interindivudual differences were found.

Berge, H. van den, Kingma, H., Kluge, C. \& Marres. E.H.M.A. (1990). Submitted for publication. 


\subsection{Introduction}

The middle ear muscle reflex has been the subject of research for many years. Following the introduction of the acoustic impedance measurements by Metz (1946), which later on resulted in the recognition of the middle ear reflex as an important diagnostic tool, research intensified. This has led to various speculations on the function of the reflex (for references see Borg, Counter \& Rösler, 1984). One of the attractive theories is that of a protective function against noise damage of the inner ear. However, several objections to this theory have been made. Firstly, the latency of the reflex is thought to be too long to protect effectively against impact noise. Secondly, the attenuation of sound transmission as a result of contraction of the muscles would only be small. Finally, a process of fatigue, which occurs during exposure to noise over a longer period of time, would restrict the protective value of the reflex. Experiments on these subjects have been intensive, but often fragmentary, and they were performed using different animal species. Since major interspecies differences exist in both structure and function of the middle ear muscles, an integrated morphological and electrophysiological study in one animal species would be required. Therefore, we initiated such an integrated study in the rat. The detailed morphological characteristics of both the tensor tympani and stapedius muscles have already been presented (Berge \& Wirtz, 1989a; Berge \& Wirtz, 1989b; Berge \& Wal, 1990). These studies showed that both muscles are able to contract fast and that they have a high fatigue resistance. As regards electrophysiology, important characteristics to be investigated are the quantitative effect on sound transmission, the latency, the rise time and the fatiguability of the reflex. In the past, determination of the effect on sound transmission was usually performed in an artificial situation, i.e. in an open loop system, for example during and after recovery of stapedius muscle paralysis (Borg, 1968; Borg \& Zakrisson, 1974; Zakrisson, 1979) and by electrical stimulation of the muscles or brainstem nuclei (Møller, 1965; Teig, 1973). Furthermore, the quantitative effect on sound transmission has often been derived indirectly from contraction force studies (Wever \& Bray, 1937, 1942; Teig, 1972a) and masking studies (Borg \& Zakrisson, 1974). The latency of the acoustic reflex has mostly been determined by the relatively indirect method of acoustic impedance measurements (see for references Bosatra et al., 1984). Finally not 
much is known of the rise time of the reflex, which is here defined as the time lapse between beginning and maximal effect on sound transmission, measured at the level of the cochlea. This characteristic is an indication for the contraction time of the muscles and determines together with the latency how fast sound transmission is influenced. We therefore set out to investigate the latency, rise time and quantitative effect on sound transmission of the acoustic reflex in the rat by direct methods, leaving both muscles and feedback system intact.

\subsection{Materials and methods.}

Ten twelve weeks old male Lewis rats were anaesthetized with ketamin $\left(\right.$ Vetalar $\left.^{\text {B }}\right)$ as this drug is assumed not to influence the middle ear muscle reflex (Bosatra et al, 1984). Following administration of 1.3 $\mathrm{ml} / \mathrm{kg}$ bodyweight of Vetalar ${ }^{\circledR}$ i.p., the anaesthesia was maintained by $0.1 \mathrm{ml}$ Vetalar ${ }^{3}$ i.m. every 30 minutes. The middle ear bulla was exposed by an retroaural approach, leaving the outer ear canal intact. The rats were placed in a fixator especially designed for this purpose. Body temperature was controlled at $38^{\circ} \mathrm{C}$ via a feed back heating system attached to the fixator. For measuring cochlear microphonics (CM), a silver ball electrode $(\emptyset 0.8 \mathrm{~mm})$ was inserted through a small hole that was made in the bulla and placed on the promontory close to the round window niche. This was done using a micromanipulator and operation stereo microscope. For recording electromyograms (EMG) a silver wire electrode was placed on the belly of the tensor tympani muscle. In both cases a reference electrode and a ground electrode were placed in the muscles near the bulla and in a hind limb, respectively. The actual experimental situation is shown in Figure 6.1a. Acoustic stimuli were administered contralaterally (i.e. the non-operated ear) and ipsilaterally (i.e. the operated ear). The former were applied to induce a (bilateral) middle ear muscle contraction, the latter to determine effects of the contraction on sound transmission (see below). The ipsilateral stimuli were generated by a Nicolet CA-2000 and the contralateral stimuli by an Acoustics AC3 audiometer or a Nicolet CA-2000. For acoustic stimulation Nicolet Model TIP-300 transducers with a tube length of $25 \mathrm{~cm}$ were used on both sides, the ends of which were inserted till close to the the tympanic membrane. The stimulus parameters indicated in this study (intensity, duration, 

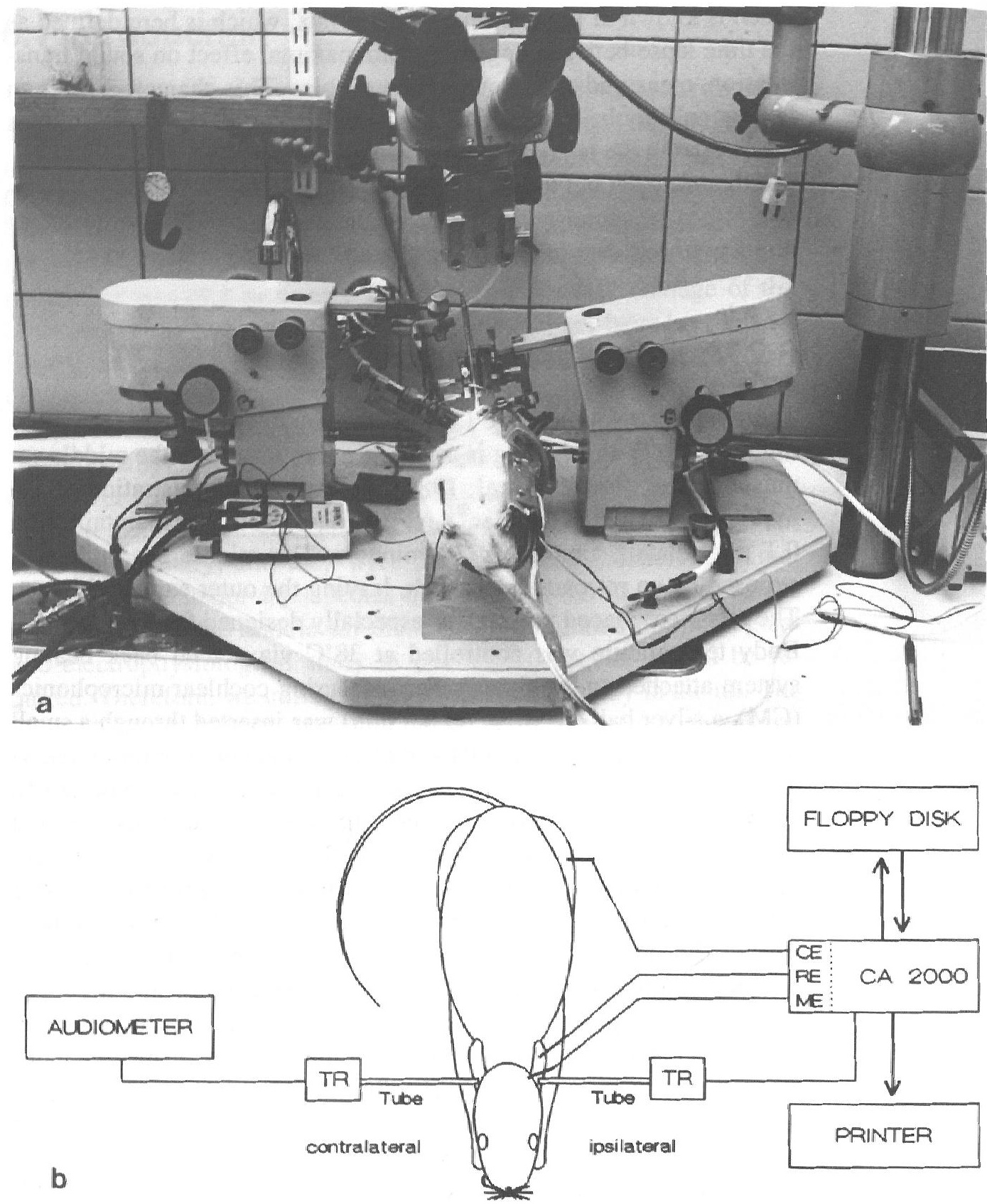

Fig. 6.1 (a,b). Experimental situation. (a) Actual experimental situation. (b) Schematic representation. $\mathrm{CE}$, ground electrode; $\mathrm{RE}$, reference electrode; $\mathrm{ME}$, recording electrode; TR, transducer; CA 2000, Nicolet CA 2000. 
frequency, envelope, repetition rate) refer to the output characteristics at the free end of the transducer tubes while these were not inserted in the ear canal.

In all experiments the Nicolet CA 2000 was used for data-acquisition and signal processing (CM and EMG). The bandwidth during registration of the CM was $150 \mathrm{~Hz}-10 \mathrm{kHz}$, and for the EMG $300 \mathrm{~Hz}-10 \mathrm{kHz}$. Figure $6.1 \mathrm{~b}$ schematically shows the stimulus situation.

Several experiments were performed to determine (a) the relation between CM-amplitude and stimulus intensity at various frequencies, (b) the latency of the reflex, (c) the rise time of the reflex, (d) the effect of the reflex on sound transmission and (e) the most effective stimulus that elicits a middle ear muscle reflex.

In order to establish the relation between $\mathrm{CM}$ amplitude and stimulus intensity 50 tone bursts with a plateau of $15 \mathrm{msec}$ and a rise and fall time of $1 \mathrm{msec}$, were given at a repetition rate of $0.3 \mathrm{~Hz}$ or $3.1 \mathrm{~Hz}$ and increasing intensity (37-112 dBSPL). The responses were averaged. Measurements were done at various frequencies $(0.25,0.5,1.0,1.5$, $2.0,4.0,8.0 \mathrm{KHz})$. The amplitudes of the $\mathrm{CM}$ were determined at $\mathrm{t}=4$ msec ( $t=0$ is onset of the stimulus) by peak to peak measurements. All $\mathrm{CM}$-amplitudes in this study were measured peak to peak. A change in CM amplitude of more than $10 \%$ was considered to be a significant change.

The latency and rise time of the reflex were determined from the change in the averaged $\mathrm{CM}$ amplitudes following 50 tone bursts of 50 msec, administered ipsilaterally and above the reflex threshold (87$112 \mathrm{dBSPL}, 0.25-8 \mathrm{kHz}$, repetition rate 3.1 or 0.3 , rise and fall time 1 $\mathrm{msec}$ ). The latency was estimated from the time between the beginning of the stimulus and beginning of the change in $\mathrm{CM}$ amplitude. The rise time was estimated from the time between the beginning and the end of a significant change in $\mathrm{CM}$ amplitude. In addition, the latency of tensor tympani muscle reflex was investigated by recording the EMG. Contraction was induced by single ipsilateral or contralateral stimuli with a duration of $15-200 \mathrm{msec}$, a frequency of $0.5,1.0,1.5,2$ or $4 \mathrm{kHz}$ and an intensity varying from 27 to $107 \mathrm{dBSPL}$. The latency was determined from the time between beginning of the stimulus and beginning of the muscular action potentials.

To determine the effect of the middle ear muscle reflex on sound transmission, contralateral acoustic stimuli of $1.5 \mathrm{kHz}, 67-107 \mathrm{dBSPL}$. were given to elicite a (bilateral) reflex. These stimuli were adminis- 
tered manually from $0.5-1.0 \mathrm{sec}$ prior to, till $0.5-1.0 \mathrm{sec}$ after ipsilaterally administered tone bursts. The ipsilateral stimulus consisted of 50 tone bursts of $67 \mathrm{dBSPL}$ (i.e. below the reflex threshold) administered with a repetition rate of $3.1 \mathrm{~Hz}$ at various frequencies $(0.25,0.5,1,1.5$, 2,4 and $8 \mathrm{kHz}$ ). Ipsilaterally, the effect of the contraction on sound transmission was determined by measuring the difference of the averaged CM amplitude of the ipsilateral stimulus with and without contralateral stimulation. The $\mathrm{CM}$ amplitude without contralateral stimulation was measured before as well as after the contralateral stimulation to check for reproducibility and and cochlear damage. Only those data sets were used for analysis of which these two $\mathrm{CM}$ amplitudes without contralateral stimulation showed a test-retest variation of less than 5 percent. An ipsilateral stimulus intensity of 67 dBSPL was chosen since this stimulus induced a CM with a good signal to noise, the stimulus did not elicit an obvious middle ear muscle contraction, and the stimulus CM amplitude logaritmic response curve showed to be linear around this intensity (see results).

The effectiveness of contralateral stimuli in eliciting the middle ear muscle reflex was determined from the difference in CM amplitude of an ipsilateral administered stimulus of $67 \mathrm{dBSPL}$ and $1.5 \mathrm{kHz}$ with and without the contralateral eliciting stimulus. Ipsilateraly, $1.5 \mathrm{KHz}$ was chosen as this frequency appeared to be very sensitive (see results). The contralateral stimulus was administered manually from $0.5-1.0$ sec prior to, till $0.5-1.0 \mathrm{sec}$ after the ipsilaterally administered 50 tone bursts (frequency: $0.25,0.5,1,1.5,2,4$ and $8 \mathrm{kHz}$ and intensity $65-115$ dBSPL). Again, reproducebility was taken into account.

The experiments were performed in ten rats. Control measurements during total muscular relaxation by Pavulon ${ }^{\text {-Vetalar }}{ }^{\text {intubation- }}$ anaesthesia and by tenotomy of the tensor tympani muscle were performed in two rats. Contraction of the tensor tympani muscle was monitored during all experiments by direct inspection using the operation microscope. 


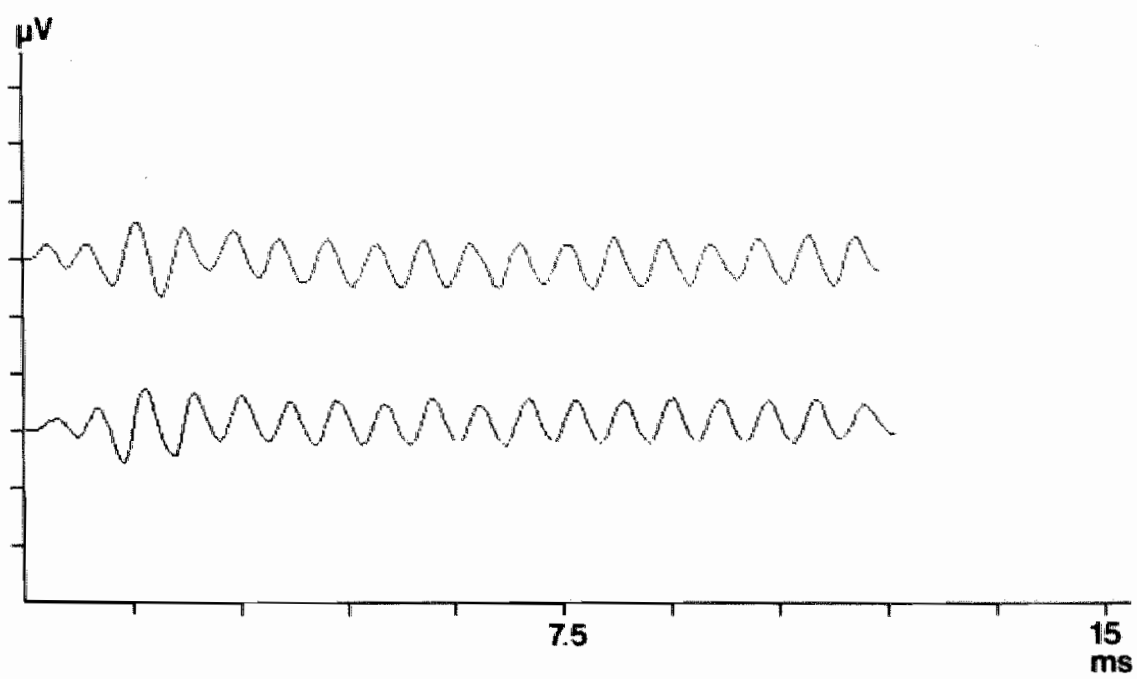

Fig. 6.2 (a,b). Examples of cochlear microphonics in the rat. (a) Averaged CM recording (stimulus duration: $50 \mathrm{msec}$; repetition frequency 3.1 ; number of stimuli: 50) of a stimulus of $67 \mathrm{dBSPL}$ at $1.5 \mathrm{kHz}$; stimulus onset at $t=0$. (b) The same recording as in (a), during Pavulon - Vetalar anaesthesia (see text).

\subsection{Results}

Figure 6.2 (trace a) shows a typical ECoch induced by ipsilateral 1.5 $\mathrm{kHz}$ sinusoidal stimulation at $67 \mathrm{dBSPL}$. In the first two msec the response shows a fast increase in amplitude, which was also seen at higher stimulus intensities. In this time lapse the response predominantly reflects contributions of the nerve action potential and the $\mathrm{CM}$. After a few msec the response amplitude decreases slightly and stabilizes. Than the sinusoidal changes of the potential most likely reflects the CM. It was not to be expected that the rapid change in $\mathrm{CM}$ amplitude in the first 1-2 msec was induced by the middle ear muscles. Nevertheless we checked this by measuring the ECoch during total muscle relaxation by anaesthesia with Pavulon ${ }^{2}$. Regardless the stimulus intensity, the initial response pattern is the same with and without total muscle relaxation (see trace b in Fig. 6.2).

In Figure 6.3a the CM amplitude of a $1.5 \mathrm{kHz}$ stimulus is plotted as a function of the stimulus intensity. The amplitudes were measured at 

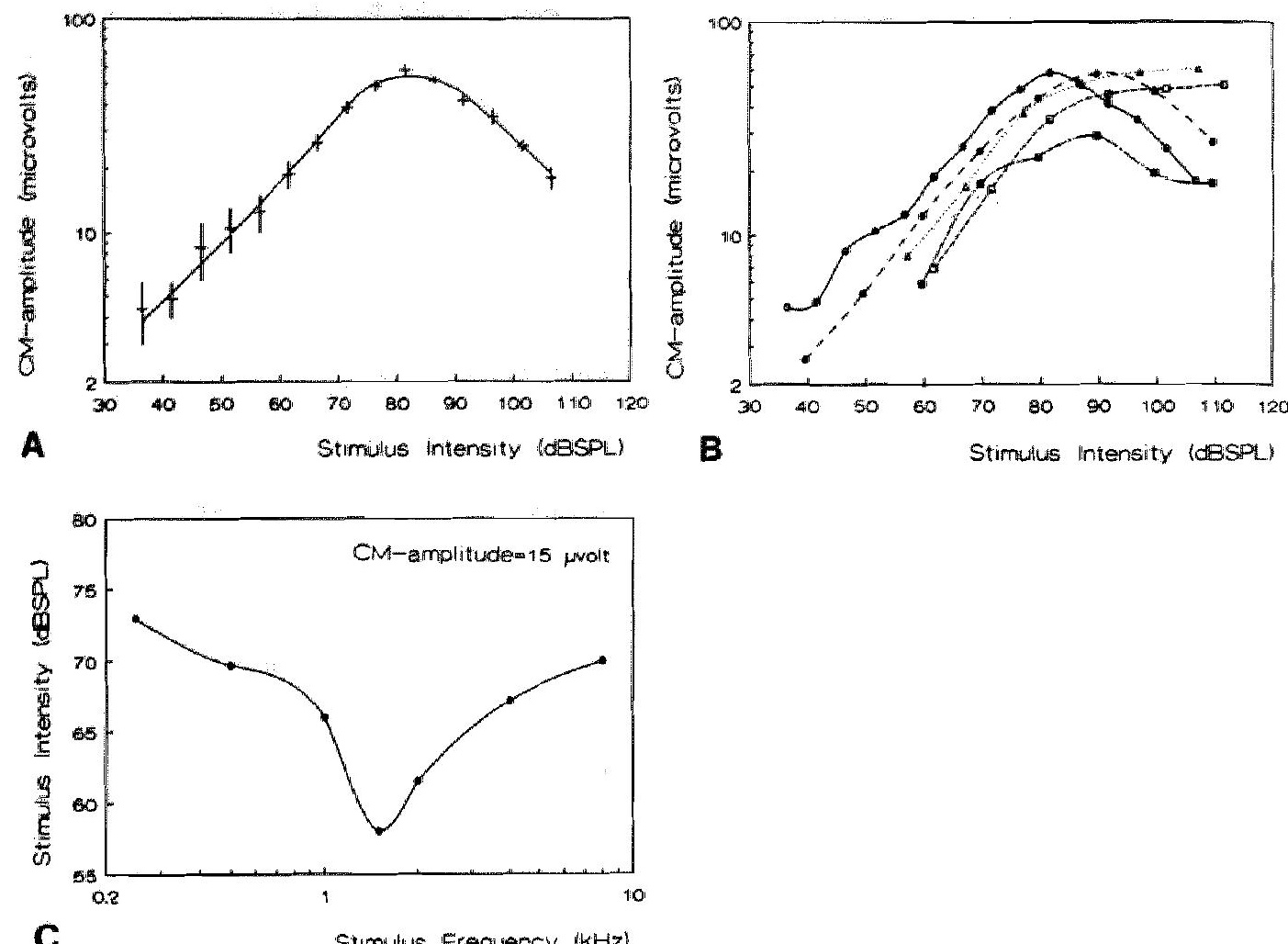

Fig. 6.3 (a-c). Relation between stimulus intensity and $\mathrm{CM}$ amplitude. (a) Mean $\mathrm{CM}$ amplitude of a stimulus of $1.5 \mathrm{kHz}$ as a function of the stimulus intensity. Vertical bars: + $/$ - 1 S.D. (b) The same form as the previous for different frequencies ( $: 0.5 \mathrm{kHz} ; \Delta \cdots \cdots: 1 \mathrm{kHz} ; \ominus-\Theta: 1.5 \mathrm{kHz} ;---2 \mathrm{kHz} ;-\longrightarrow: 4 \mathrm{kHz})$. (c) Sensitivity curve of the $\mathrm{CM}$ amplitude. The curve represents the mean intensity required to induce a $15 \mu \mathrm{V} \mathrm{CM}$ amplitude as a function of stimulus frequency (a-c: $\mathrm{N}=4$ )

$t=4$ msec $(t=0$ is onset of the stimulus). There is a linear rellationship upto $74 \mathrm{~dB}$, whereas above $74 \mathrm{dBSPL}$ a saturation, and above 87 dBSPL a diminuation occurs. There are only slight interindividual differences in amplitudes between the various rats $(N=4)$. The relationship between the $\mathrm{CM}$ response amplitude and stimulus intensity depends on frequency as is shown in Figure 6.3b. Figure 6.3c shows the sensitivity curve of the $\mathrm{CM}$ amplitude. The intensity required to induce 


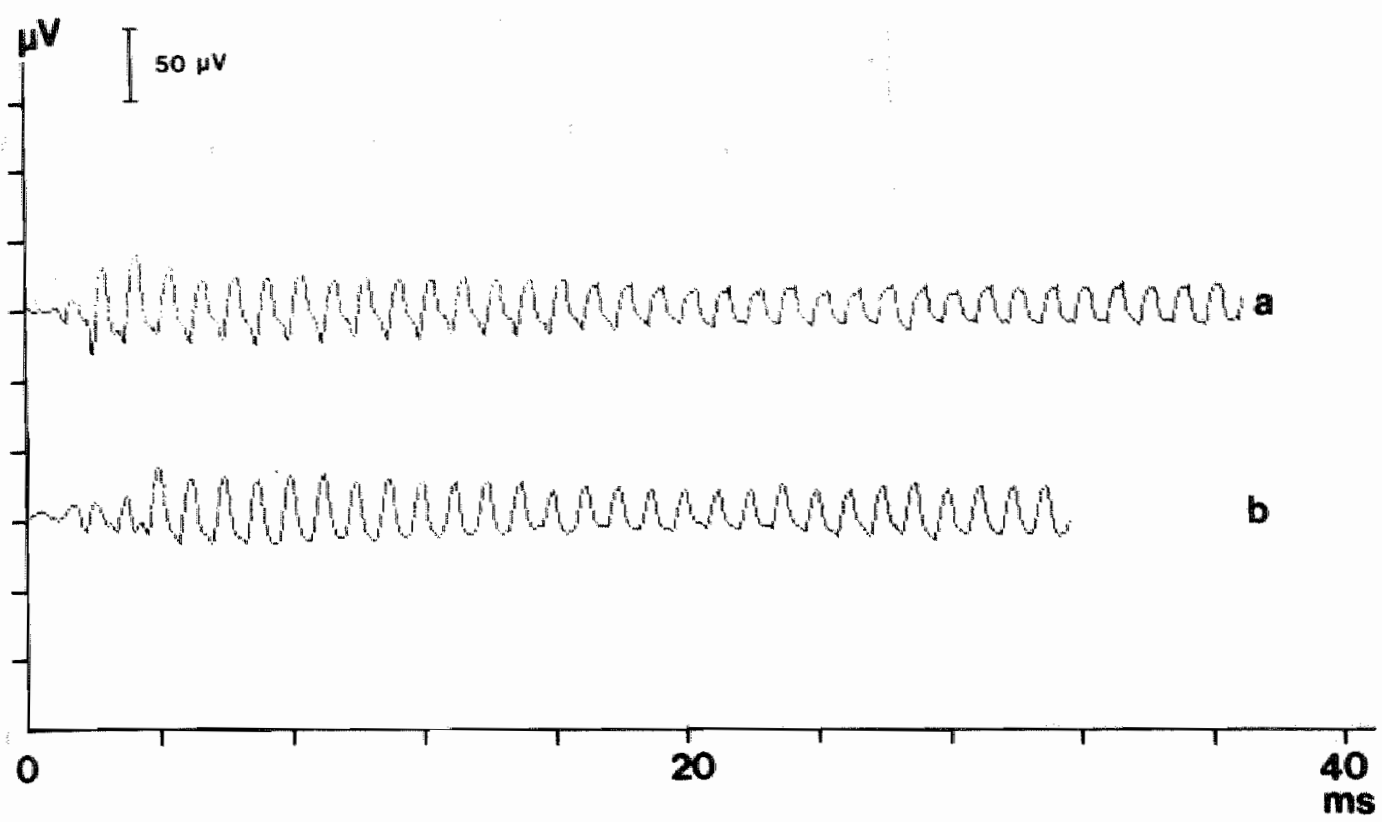

Fig. 6.4 (a,b). (a) Averaged CM recording of a $107 \mathrm{dBSPL}, 1 \mathrm{kHz}$ stimulus. (stimulus duration: $50 \mathrm{msec}$; repetition frequency 3.1 ; number of stimuli: 50 ). (b) The same form as the previous, however, tensor tympani muscle tenotomized (see text).

an $\mathrm{CM}$ amplitude of $15 \mu \mathrm{V}$ is plotted as a function of the stimulus frequency. It can be seen that the maximal sensitivity is found at 1.5 $\mathrm{kHz}$. At stimulus intensities above $77 \mathrm{dBSPL}$ the response pattern appears to be less sinusoidal for most frequencies. Furthermore, at these higher stimulus intensities (Fig 6.4., trace a) the amplitude of the response appears to decrease after about $15-30 \mathrm{msec}$ depending on the stimulus intensity. The decrease itself takes about $5-15 \mathrm{msec}$. This response pattern is the same at low $(0.3 \mathrm{~Hz})$ and at higher $(3.1 \mathrm{~Hz})$ stimulus repetition rates. The time lapse between the beginning of the stimulus and the beginning of the decrease of the $\mathrm{CM}$ amplitude represents the latency of the middle ear muscle reflex. Figure 6.4 trace $a$, depicts the $C M$ with both muscles intact. Trace b shows the CM recorded following tenotomy of the tensor tympani muscle. In both situations the amplitude of the CM starts to decrease at about $15 \mathrm{msec}$. However, the amplitude of the CM decreases more with both muscles 


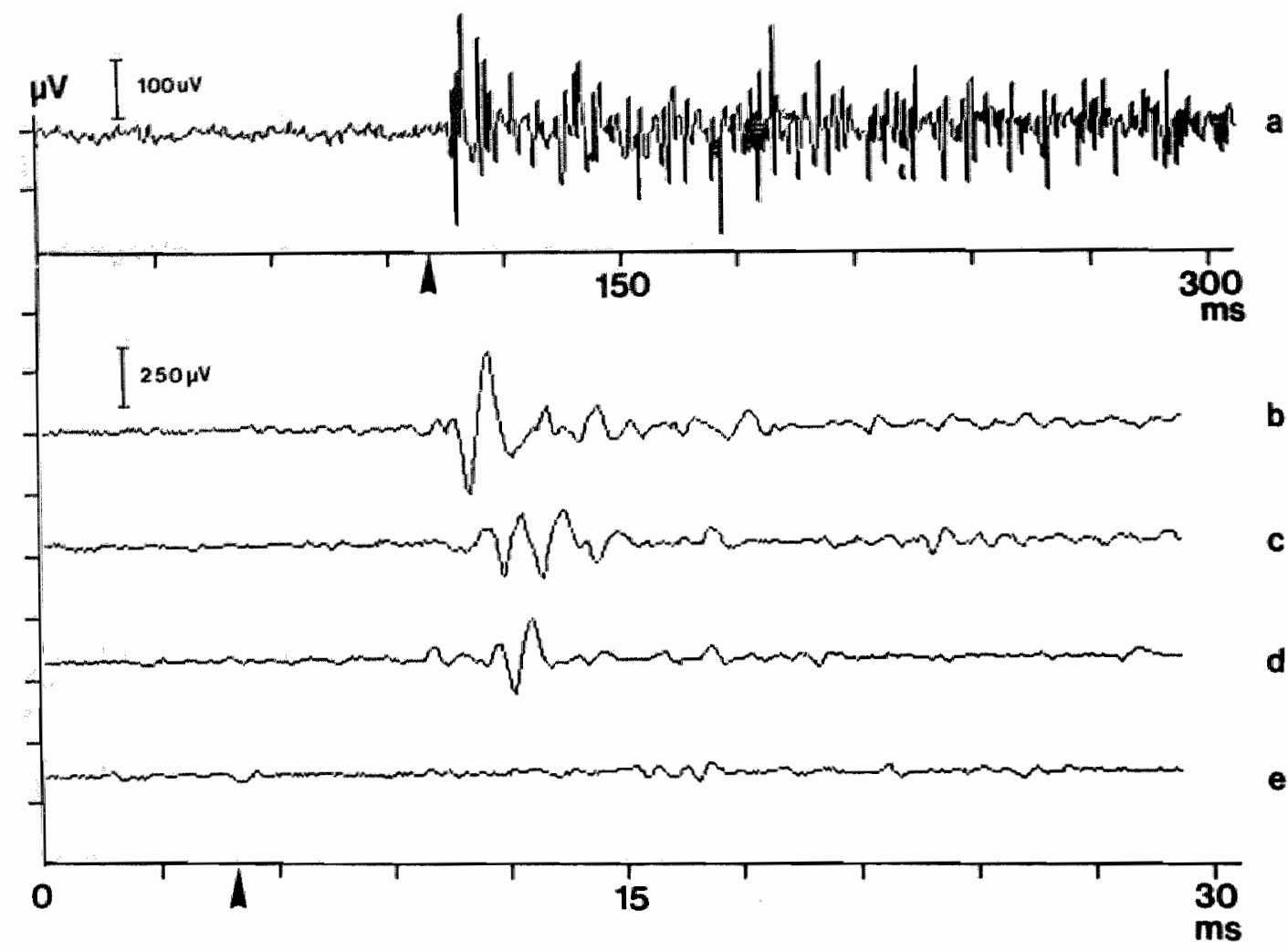

Fig. 6.5 (a-e). EMG recordings of the tensor tympani muscle. (a) Example of EMG response following a $107 \mathrm{dBSPL}$ stimulus at $2 \mathrm{kHz}$. (b-e) EMG responses at a shorter time scale at decreasing stimulus intensity following a tone burst of $2 \mathrm{kHz}$. (b) 107 dBSPL. (c) $97 \mathrm{dBSPL}$. (d) $87 \mathrm{dBSPL}$. (e) $77 \mathrm{dBSPL}$. Arrow: beginning of the stimulus (see text).

intact. Furthermore with the tensor tympani muscle tenotomized the decrease is followed by a slight increase of the CM amplitude at about $15 \mathrm{msec}$. In order to estimate the beginning of the muscular potentials of the tensor tympani muscle EMG recordings were made. Figure 6.5 shows the recordings of the EMG of the tensor tympani muscle at two different time scales (traces a and b-d respectively). The muscle potentials could be induced by both ipsi- and contra lateral auditory stimulation. We recorded these potentials when the recording electrode was 


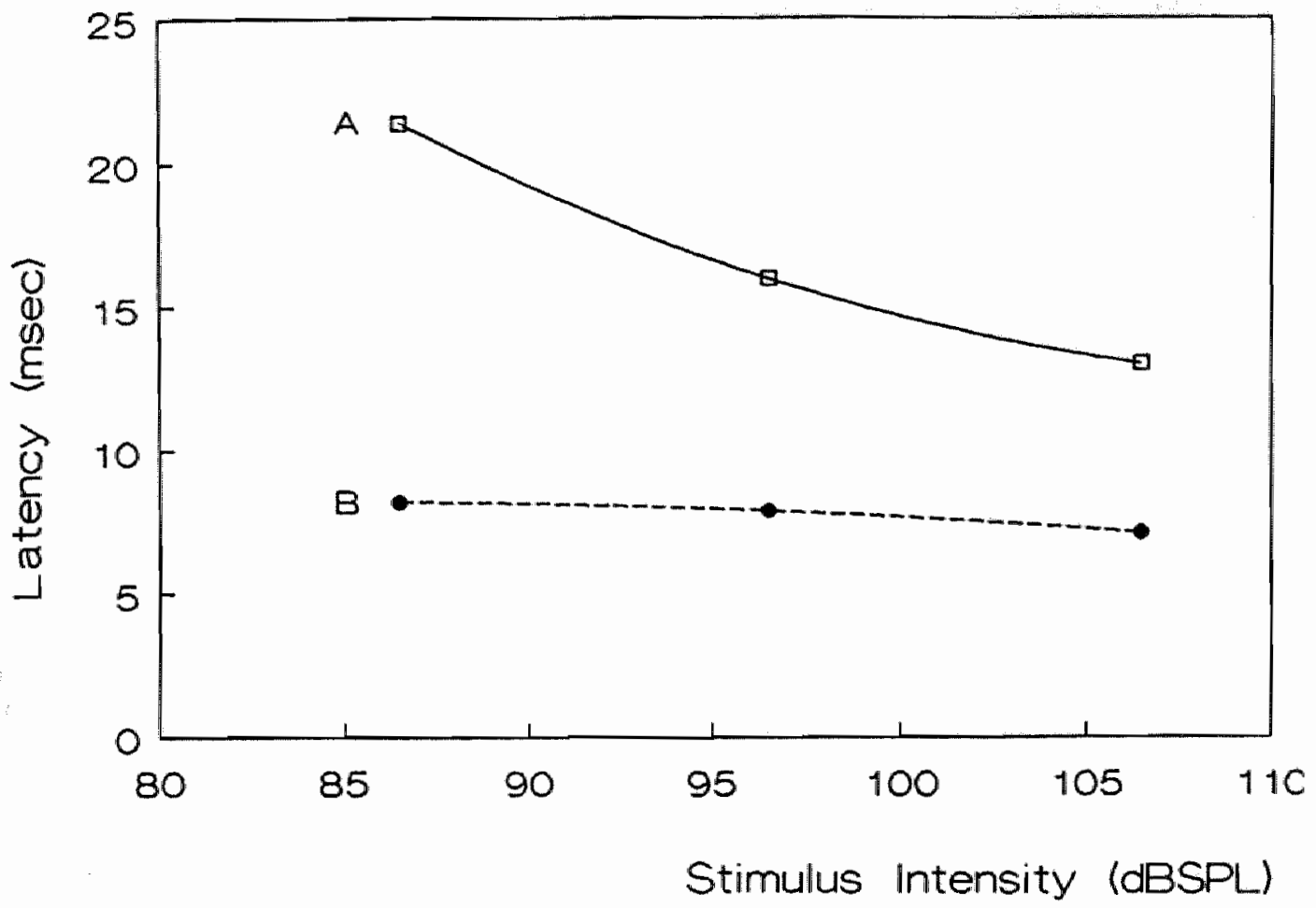

Fig. 6.6. Latency of the middle ear muscle reflex. Curve a: mean latency determined by $\mathrm{CM}$ recordings as a function of stimulus intensity $(\mathrm{N}=5)$. Curve $\mathrm{b}$ : mean latency of the EMG response of the tensor tympani muscle $(\mathrm{N}=2)$ (see text).

placed on the belly of the tensor tympani. No such potentials could be detected when this electrode was placed on the promontory. This confirms that these potentials are generated in the tensor tympani muscle and not in the muscles surrounding the bulla. The amount of EMG activity increases with increasing stimulus intensity. Figure $6.5 \mathrm{~b}-\mathrm{d}$ show that the latency of the muscle responses decreases only slightly with increasing stimulus intensity. In contrast, a marked decrease of the latency is estimated from the CM recordings measurements. This is depicted in Figure 6.6, which shows the latency of the reflex as a function of stimulus intensity determined by $\mathrm{CM}$ recordings (curve a) and the latency of the tensor tympani muscle determined by EMG recordings (curve b). Furthermore, the curves show that the 


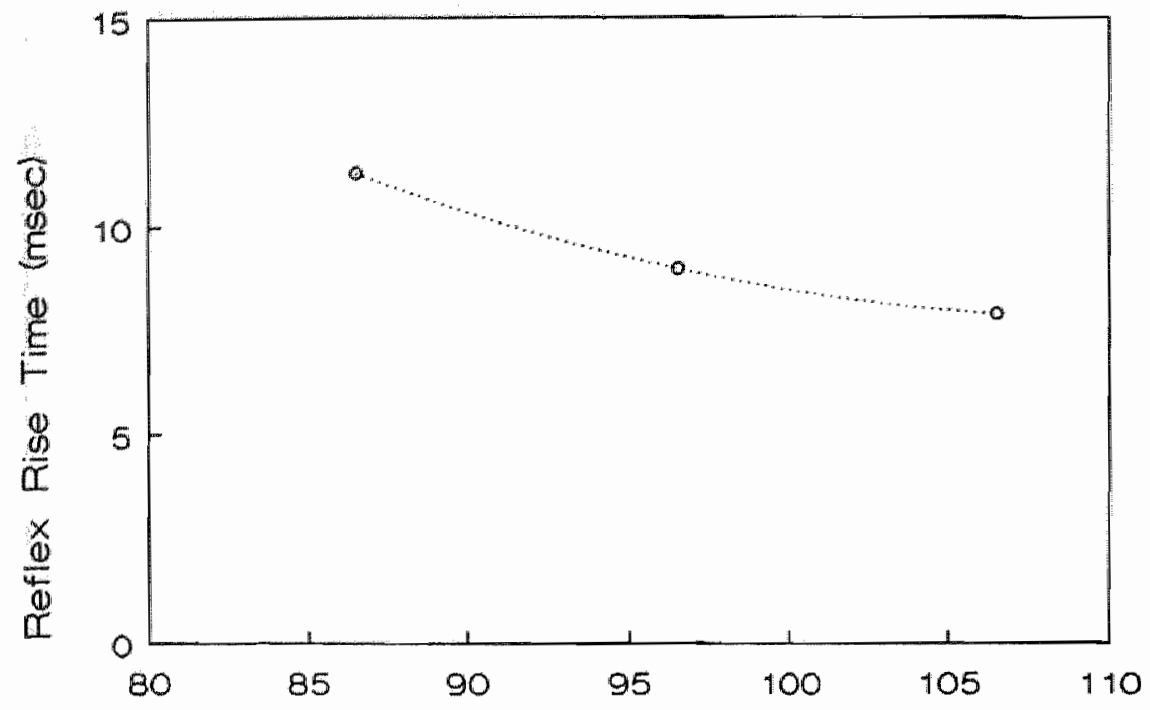

Stimulus Intensity (dBSPL)

Fig. 6.7. Mean rise time of the middle ear muscle reflex as a function of stimulus intensity $(\mathrm{N}=5)$ (see text).

change in CM amplitude-latency is longer than the EMG-latency at every stimulus intensity. The latency decreases with increasing stimulus intensity.

Figure 6.7 shows the mean time lapse between the beginning to the end of the decrease of the $\mathrm{CM}$ amplitude (rise time of the middle ear muscle reflex) as a function of stimulus intensity with both middle ear muscles intact. The rise time varies from 6.6 to $11.7 \mathrm{msec}$ and decreases at higher stimulus intensities.

In Figures 6.8 and 6.9 the effect of the contralaterally induced middle ear muscle reflex on the $\mathrm{CM}$ amplitude of tones of various frequencies is shown. Examples of CM recordings with and without contralateral continuous stimulation are shown in Figure 6.8 (traces a and b). These show that contralateral stimulation with a stimulus of $97 \mathrm{dBSPL}$ at 1.5 $\mathrm{kHz}$ causes a decrease of the CM amplitude of the ipsilaterally administered stimulus ( $67 \mathrm{dBSPL}, 1.5 \mathrm{KHz}$ ). The lower two traces (c and d) show the same stimulus situation during total muscle relaxation by Pavulon ${ }^{(2)}$-Vetalar ${ }^{\circledR}$ anaesthesia. Contralateral stimulation (trace d) did 


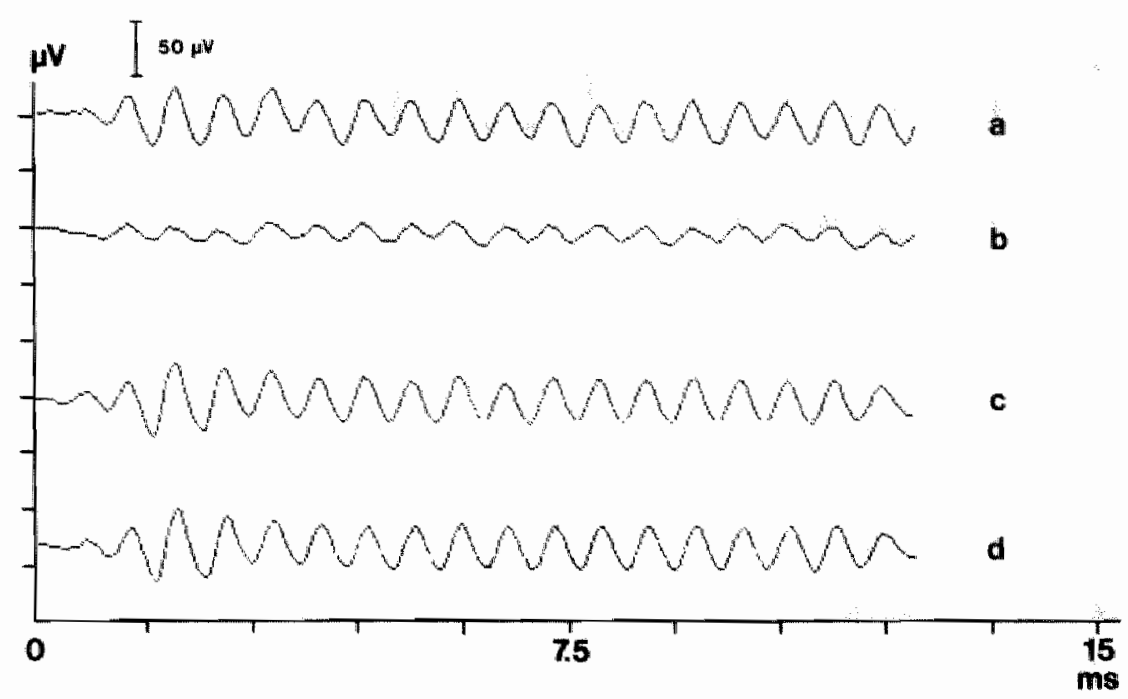

Fig. 6.8 (a-d). The effect of a contralaterally induced middle ear muscle reflex on the $\mathrm{CM}$ amplitude of an ipsilaterally administered stimulus, without and with total muscular relaxation. (a) CM response of a $67 \mathrm{~dB}$ SPL $1.5 \mathrm{kHz}$ tone (averaged. response of 50 tone bursts administered at a repetition rate of $3.1 \mathrm{~Hz}$, stimulus rise time: $1 \mathrm{msec}$; single stimulus duration: $15 \mathrm{msec}$ ), (b) CM response of the same stimulus as in (a), during contralateral stimulation with a $97 \mathrm{dBSPL}$ and $1.5 \mathrm{kHz}$ tone. (c-d) The same stimulus situation as in a-b respectively, however, during Pavulon ${ }^{-}$-Vetalar ${ }^{\oplus}$ anaesthesia. Note the decrease in $\mathrm{CM}$ amplitude during contralateral stimulation (b versus a). This effect disappears during total muscular relaxation (c-d).

not affect the CM amplitude anymore. Inspection of the tensor tympani muscle with the operation microscope did not reveal any sign of contraction in this situation.

In Figure 6.9a the mean change in CM amplitude of ipsilateral stimuli of $67 \mathrm{dBSPL}$ at various frequencies (+/- 1 standard deviation (S.D.)) caused by $97 \mathrm{dBSPL}$ contralateral stimulation (1.5 kHz) is shown. As can be seen in the figure, for most intensities, the maximal change was found at $1 \mathrm{kHz}$, whereas lower and higher frequencies decreased less. The S.D. is relatively large. Figure $6.9 \mathrm{~b}$ shows the curves at various intensities of the contralateral stimulus. Here too, the maximal decrease in $\mathrm{CM}$ amplitude occurs at $1 \mathrm{kHz}$. This is shown in another way 

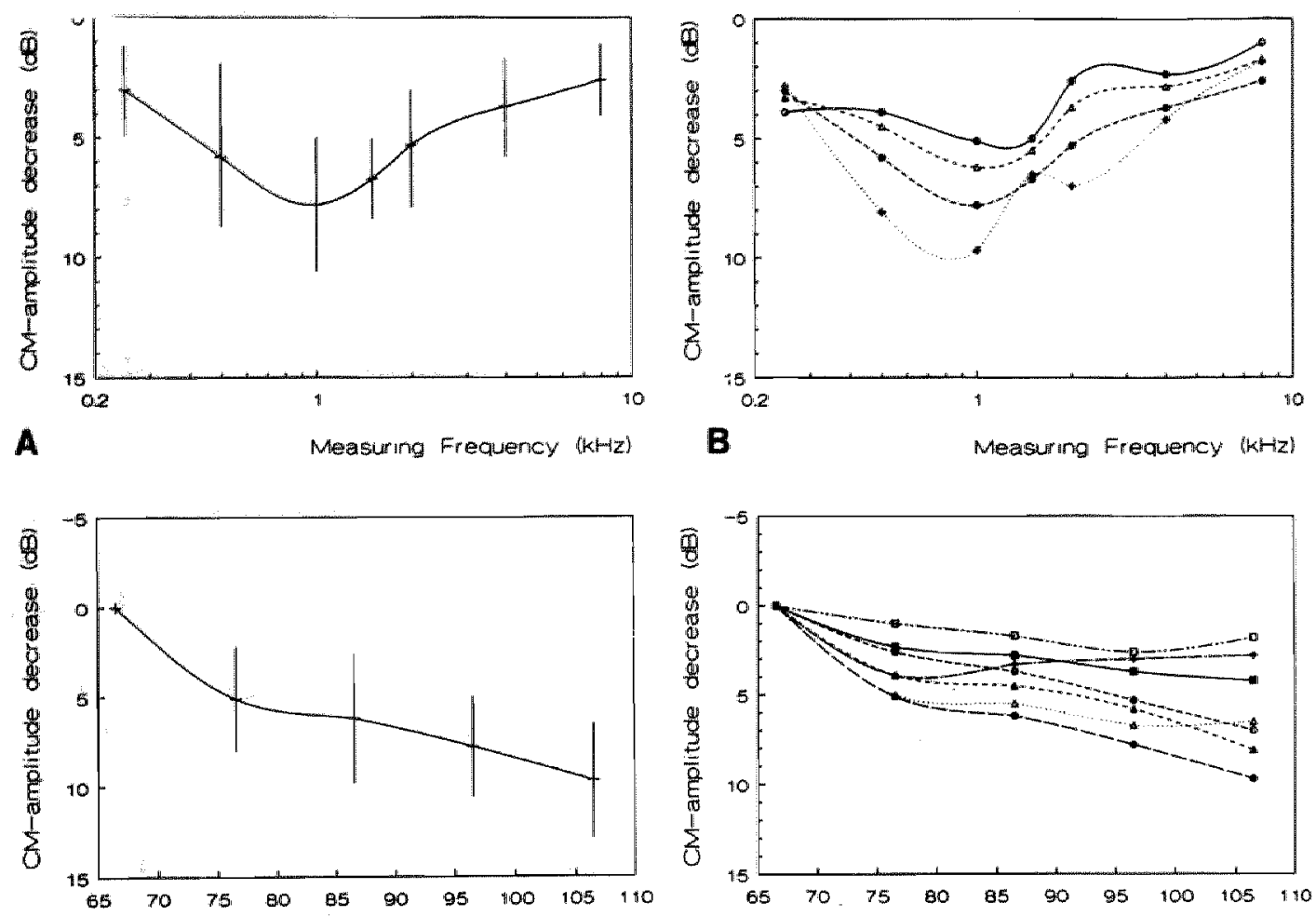

C

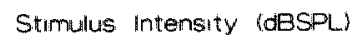

D
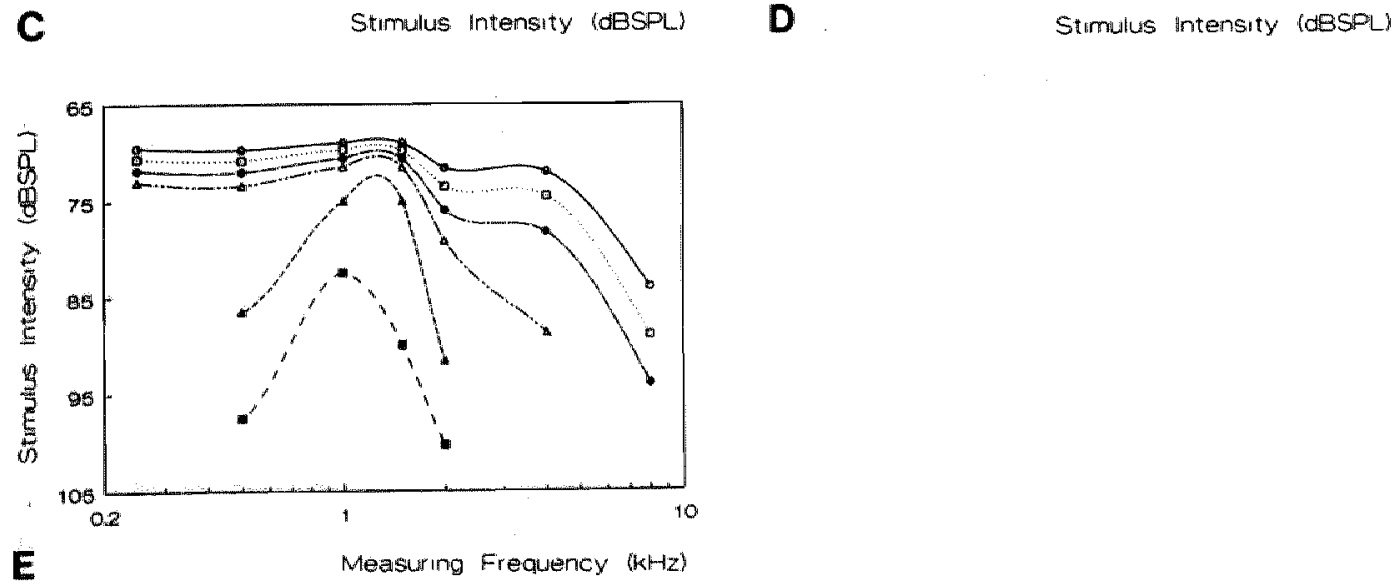
in Figure 6.9e: the curves are drawn through points of equal change in $\mathrm{CM}$ amplitude. For $1 \mathrm{kHz}$ relatively low stimulus levels are required to obtain maximal decrease in CM amplitude. In Figure $6.9 \mathrm{c}$ and $9 \mathrm{~d}$ the change in CM amplitude of various frequencies is plotted versus the intensity of the contralateral stimulus. For $1 \mathrm{kHz}$ (Fig. 6.9c), the CM amplitude decreases with increasing stimulus intensity. The mean maximal decrease in $\mathrm{CM}$ amplitude at this frequency is $9-10 \mathrm{~dB}$. Figure $6.9 \mathrm{~d}$ shows the intensity dependance at other frequencies.

Figure 6.10 shows the influence of the frequency and the intensity of contralateral (middle ear muscle reflex eliciting) stimulus on the $\mathrm{CM}$ amplitude of the $67 \mathrm{~dB}, 1.5 \mathrm{kHz}$ ipsilateral stimulus. Figure $6.10 \mathrm{a}-\mathrm{b}$ illustrate that the frequencies above $2 \mathrm{kHz}$ are the most effective stimulus frequencies in inducing a middle ear muscle reflex. This trend of lower frequencies being less effective then higher frequencies is found for all stimulus intensities. Furthermore, the CM amplitude decreases somewhat more with increasing stimulus intensity. This is more clearly shown in Figure $6.10 \mathrm{c}-\mathrm{d}$, where attenuation is plotted against stimulus intensity. The effectiveness of the contralateral stimulus is shown in another way in Figure 6.10e. The iso-change in CM amplitude-curves show that the stimulus is most effective around 2.5 $\mathrm{kHz}$.

Fig. 6.9 (a-e). The effect of contralaterally induced contraction of the middle ear muscles on CM amplitudes of ipsilaterally administered tones. (a) The effect of contralateral stimulation ( $97 \mathrm{dBSPL}, 1.5 \mathrm{kHz})$ on the mean CM amplitudes $(+\% 1$ S.D.) of ipsilaterally administered $67 \mathrm{~dB}$ tones with various frequencies, (b) The same form as the previous; with increasing contralateral stimulus intensity (77-107 dBSPL) $(\Theta-\Theta: 77 \mathrm{dBSPL} ; \mathrm{A}--\mathrm{A}: 87 \mathrm{dBSPL} ;-\ldots$ - $97 \mathrm{dBSPL} ;+\cdots . .+$ $: 107 \mathrm{dBSPL})$. (c), The same stimulus situation as in $(\mathrm{a}-\mathrm{b})$; decrease in $\mathrm{CM}$ amplitude of $\mathbb{k H z}$ tones plotted as a function of contralateral stimulus intensity $(+/-1 \mathrm{~S} . \mathrm{D}$.).

(d) The same form as (c), for different frequencies $(0.25-8 \mathrm{kHz}) .(+\rightarrow: 0.25$ $\mathrm{kHz} ;-\cdots: 0.5 \mathrm{kHz} ;-\longrightarrow: 1 \mathrm{kHz} ; \Delta \cdots \cdot \Delta: 1.5 \mathrm{kHz} ; 0--\mathrm{O}: 2 \mathrm{kHz}$; - $4 \mathrm{kHz} ; \square-. \square: 8 \mathrm{kHz}$. (e), iso-decrease in CM amplitude curves; frequency (ipsilateral) as a function of stimulus intensity (contralateral). $\ominus-\Theta: 1.5 \mathrm{~dB}$;

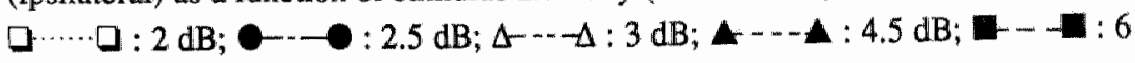
dB. $\left(a-e^{*} N=6\right)$. 

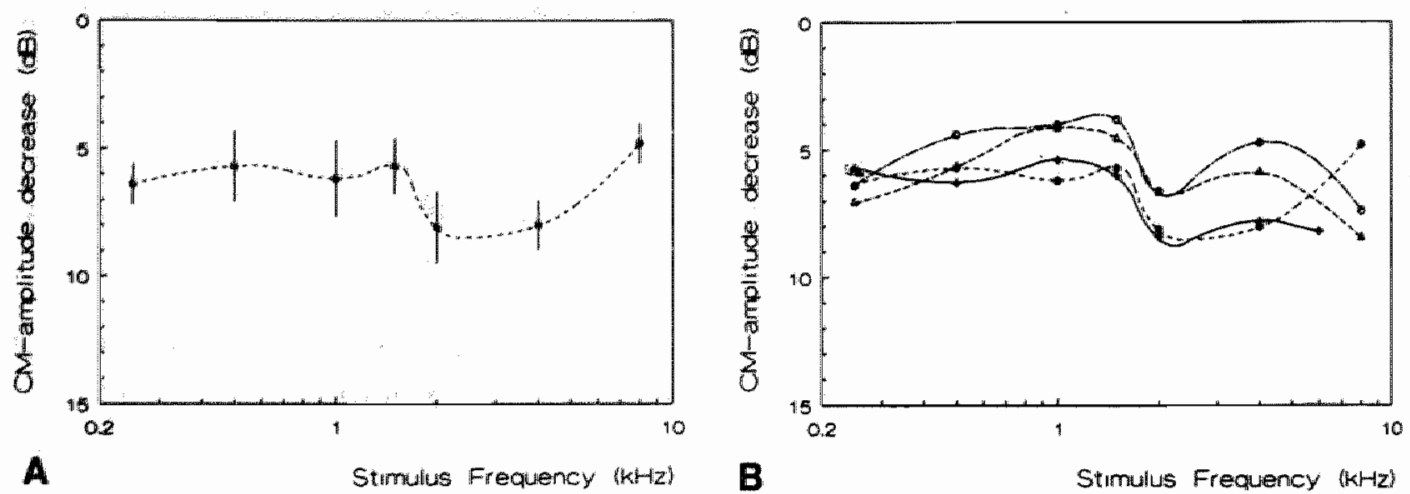

B

Sitımulus Frequency ("6hz)
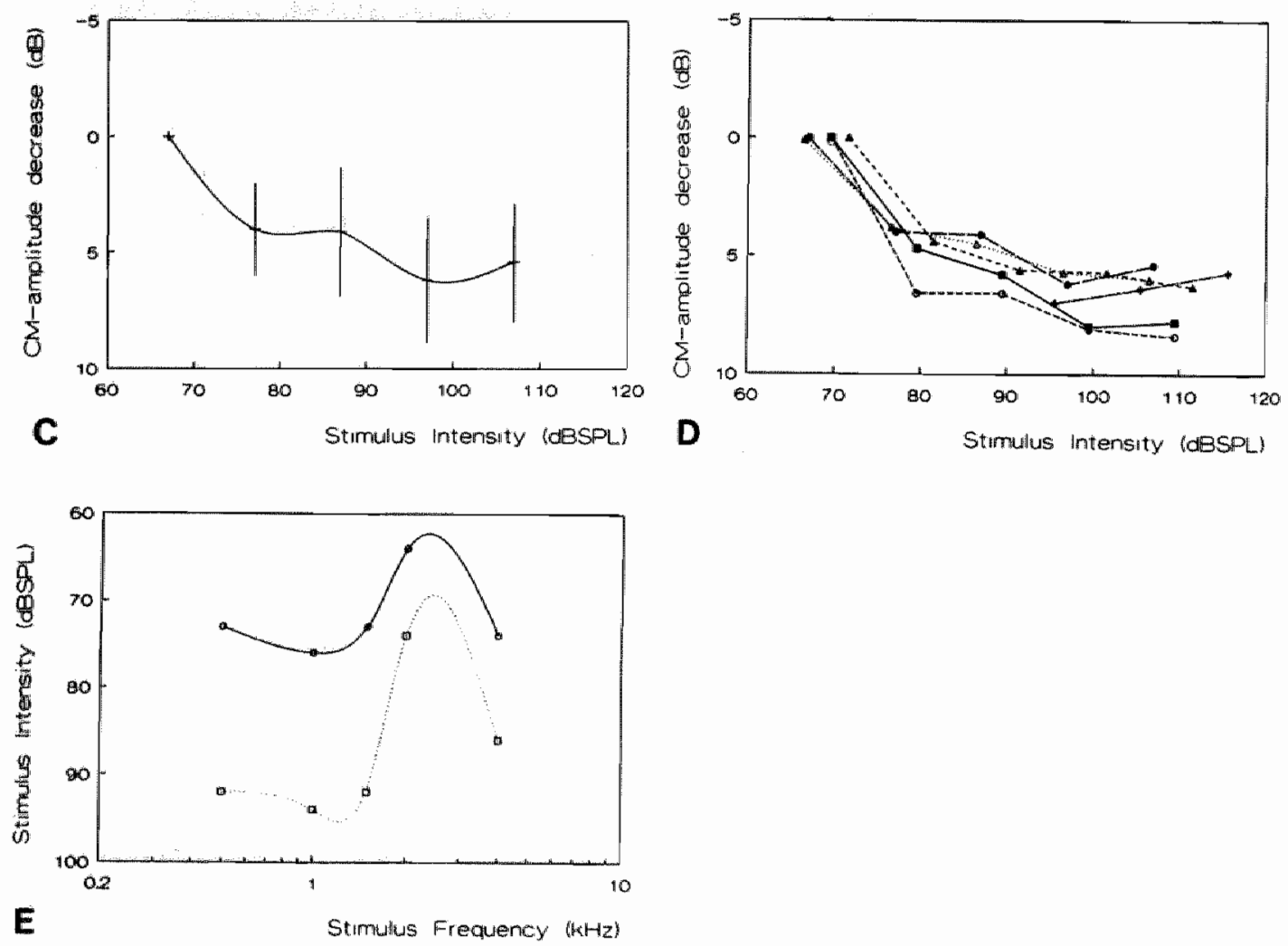


\subsection{Discussion}

The aim of this study was to investigate the latency of the middle ear muscle reflex, the rise time of the reflex and the effect of the middle ear muscle reflex on sound transmission.

The latency of the acoustic reflex can be measured by various methods. However, the most direct methods are EMG and the recording of the CM. From the recordings of the CM it was shown that reflex latency in the rat is very short. While it was shown that both muscles take part in the acoustic reflex in the rat, no differentiation in latency of the two muscle was revealed. When the tensor tympani muscle was cut, the rise time of the reflex was shorter and the attenuation smaller. However, the latency did not change. This would indicate that the latency of the stapedius muscle reflex is at least the same, but possibly shorter than that of the tensor tympani muscle reflex. In most mammals the latency of the stapedius muscle is shorter than that of the tensor tympani muscle, while in man only the stapedius muscle is believed to be active in the acoustic reflex (Borg, Counter and Rösler, 1984). The EMG's of the tensor tympani muscle shows that the reflex latency of the muscle detected by EMG is shorter than the latency of the reflex detected by $\mathrm{CM}$ recordings. This difference can be ascribed to the time needed for the build up of the muscle contraction, the increase of stifness of the ossicular chain and the ultimately resulting decrease of the CM amplitude. Compared to most other mammals the

Fig. 6.10 (a-e). The influence of the frequency and the intensity of contralateral acoustic stimuli in eliciting the middle ear muscle reflex. (a) Mean change in CM amplitude ( $+1-1$ S.D.) of a $67 \mathrm{dBSPL} 1.5 \mathrm{kHz}$ tone (averaged response of 50 tone bursts administered at a repetition rate of $3.1 \mathrm{~Hz}$, stimulus risetime: $1 \mathrm{msec}$; single stimulus duration: $15 \mathrm{msec}$ ) as a function of the contralateral stimulus frequency at 97 dBSPL (eliciting a middle ear muscle reflex). (b) The same form as the previous, at $77-107$ dBSPL. $(\Theta-\Theta: 77-84$ dBSPL; $\triangle---\Delta: 87-94 \mathrm{dBSPL}$; 97-104 dBSPL; $++: 107-114 \mathrm{dBSPL}$ ). (c) The change in CM amplitude plotted as a function of (contralateral) stimulus intensity at $1 \mathrm{kHZ}(+/-1$ S.D.). (d) The same form as the previous, at $0.25-8 \mathrm{kHz}$. $-+0.25 \mathrm{kHz} ; \triangle--\perp: 0.5 \mathrm{kHz}$;

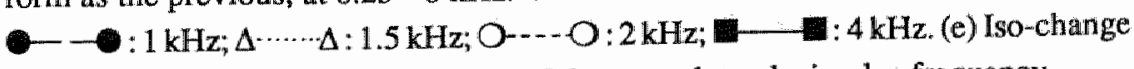
in $\mathrm{CM}$ amplitude curves as a function of the contralateral stimulus frequency, $\ominus-\theta: 3 \mathrm{~dB} ; \square \cdots \cdots \cdot \square: 6 \mathrm{~dB}$. (a-e: $\mathrm{N}=6$ ). 
latency of the tensor tympani response in the rat measured by EMG is relatively short (See Wersäll, 1958; Fisch \& Schulthess, 1963). Only the latency of tensor tympani response in the mouse and cat, which were also measured by EMG, were shown to be as short as about 4 and 7 msec respectively (Horner, 1986; Eliasson, 1955). One should be careful to compare all these results as the latency depends on various stimulus characteristics as rise time, frequency and intensity of the activating stimulus (Bosatra et al., 1984). Furthermore, as was shown in this study, latency depends on the method of measurement (e.g. EMG, ECoch, tympanometry). The latency determined by the diminuation of the amplitude of the CM's seems to be the most relevant one, as it reflects the influence of the muscles on sound transmission at the level of the cochlea.

The change in CM amplitude in time most likely results from the contraction of the middle ear muscles as, firstly, this phenomenon disappeared during total muscular relaxation, secondly, it was influenced by tenotomy of the tensor tympani muscle, and thirdly it was proceeded by muscle activation (EMG). The time lapse between the beginning and the end of the decrease of the $\mathrm{CM}$ amplitude reflects the rise time of the reflex. This time period can be considered as a measure for the contraction time of the muscles. From our results no differentiation could be made between the rise time of the tensor tympani and stapedius muscle reflexes. In the past, measurements of the contraction time have been done by stimulating the motor nerves of the muscles (Wersäll, 1958; Teig, 1972a). Teig (1972a) showed that with supramaximal stimulation of the motor nerves, the contraction time of the muscles in the cat and rabbit was $20-30 \mathrm{msec}$. This confirmed findings of Wersall (1958) who found a contraction time of the stapedius muscle in the rabbit of about $20 \mathrm{msec}$. The rise time of about 7-12 msec for both muscles together in our study is very short and supports the results of morphological studies which showed that both muscles are composed of mainly fast twitch muscle fibres (Berge \& Wirtz, 1989a; Berge \& Wirtz, 1989b). This, together with the relatively short latency of the reflex suggests that the acoustic reflex in the rat has a very fast reaction pattern.

As regards the effect on sound transmission it became clear that the mean decrease of $\mathrm{CM}$ amplitude in the rat is maximally about $10 \mathrm{~dB}$ at $1 \mathrm{KHz}$. From the slope of the stimulus intensity versus $\mathrm{CM}$-amplitude curve of $1 \mathrm{KHz}$ (Fig. 6.3b), it can be calculated that this corresponds 
with an attenuation of sound transmission of about $15 \mathrm{dBSPL}$. This is less in comparison with findings in the cat and rabbit (Teig, 1972a; Teig, 1973) and in man (Borg, 1968; Borg \& Zakrisson, 1974). However several aspects have to be considered. First of all, in this study measurements were performed in a closed loop system, whereas in most other studies an open loop system was employed and attenuation was calculated from indirect methods like monaural masking in patients with stapedial paralysis (Borg \& Zakrisson, 1974) and contraction force studies (Teig, 1972a). The physiological closed loop situation implicates, in this case, that when the middle ear muscles are activated, attenuation occurs, resulting in a diminished sound level. As a result the action of the muscles might be adjusted to this lower level as was shown in Figure 6.4 curve b, ultimately resulting in a steady state. Secondly, measurements were performed only up to $107 \mathrm{dBSPL}$ for most frequencies. This was done because measurements took many hours and had appeared to result in inner ear damage at higher sound levels in pilot studies. Finally, our data were derived from contralateral activation of the middle ear muscle reflex. Activation of the reflex might occur at lower intensities and can result in higher attenuation when stimulated ipsilaterally or bilaterally.

As regards the stimulus intensity-attenuation curves, it was shown that the largest effect occurred between 65-77 dBSPL. Further increase of the stimulus intensity did not result in a larger increase of attenuation. This could possibly be explained by finding of Teig (1973) who showed in the cat that stronger contractions gave less reduction of sound transmission per gram tension. In summary it seems that the maximum possible attenuation is about $15 \mathrm{dBSPL}$.

The finding that tones of $1 \mathrm{kHz}$ are attenuated most is difficult to explain. In most animals attenuation is maximal at lower frequencies and decreases towards higher frequencies. Probably, for the rat, $1 \mathrm{kHz}$ is a frequency that needs attenuation, possibly to avoid masking of higher tones. In addition it appeared that the higher tones were the most effective elicitor of the middle ear muscle reflex. This might indicate the importance of high tones for the rat. Sensitivity studies of the CM in the rat have shown a maximum sensitivity at $3 \mathrm{kHz}$ and 40 $\mathrm{kHz}$ (Crowley \& Hepp-Reymond, 1966). However in the Lewis rat we found a maximum sensitivity at $1.5 \mathrm{kHz}$ (Fig. 6.3c). This seems to be paradoxal since attenuation is most at $1.0-1.5 \mathrm{KHz}$. In summary, the acoustic reflex in the rat shows to be fast reactive both in latency and 
latency of the tensor tympani response in the rat measured by EMG is relatively short (See Wersäll, 1958; Fisch \& Schulthess, 1963). Only the latency of tensor tympani response in the mouse and cat, which were also measured by EMG, were shown to be as short as about 4 and 7 risec respectively (Homer, 1986; Eliasson, 1955). One should be careful to compare all these results as the latency depends on various stimulus characteristics as rise time, frequency and intensity of the activating stimulus (Bosatra et al., 1984). Furthermore, as was shown in this study, latency depends on the method of measurement (e.g. EMG, ECoch, tympanometry). The latency determined by the diminuation of the amplitude of the CM's seems to be the most relevant one, as it reflects the influence of the muscles on sound transmission at the level of the cochlea.

The change in CM amplitude in time most likely results from the contraction of the middle ear muscles as, firstly, this phenomenon disappeared during total muscular relaxation, secondly, it was influenced by tenotomy of the tensor tympani muscle, and thirdly it was proceeded by muscle activation (EMG). The time lapse between the beginning and the end of the decrease of the $\mathrm{CM}$ amplitude reflects the rise time of the reflex. This time period can be considered as a measure for the contraction time of the muscles. From our results no differentiation could be made between the rise time of the tensor tympani and stapedius muscle reflexes. In the past, measurements of the contraction time have been done by stimulating the motor nerves of the muscles (Wersäll, 1958; Teig, 1972a). Teig (1972a) showed that with supramaximal stimulation of the motor nerves, the contraction time of the muscles in the cat and rabbit was $20-30 \mathrm{msec}$. This confirmed findings of Wersatl (1958) who found a contraction time of the stapedius muscle in the rabbit of about $20 \mathrm{msec}$. The rise time of about 7-12 msec for both muscles together in our study is very short and supports the results of morphological studies which showed that both muscles are composed of mainly fast twitch muscle fibres (Berge \& Wirtz, 1989a; Berge \& Wirtz, 1989b). This, together with the relatively short latency of the reflex suggests that the acoustic reflex in the rat has a very fast reaction pattern.

As regards the effect on sound transmission it became clear that the mean decrease of $\mathrm{CM}$ amplitude in the rat is maximally about $10 \mathrm{~dB}$ at $1 \mathrm{KHz}$. From the slope of the stimulus intensity versus $\mathrm{CM}$-amplitude curve of $1 \mathrm{KHz}$ (Fig. 6.3b), it can be calculated that this corresponds 
with an attenuation of sound transmission of about $15 \mathrm{dBSPL}$. This is less in comparison with findings in the cat and rabbit (Teig, 1972a; Teig, 1973) and in man (Borg, 1968; Borg \& Zakrisson, 1974). However several aspects have to be considered. First of all, in this study measurements were performed in a closed loop system, whereas in most other studies an open loop system was employed and attenuation was calculated from indirect methods like monaural masking in patients with stapedial paralysis (Borg \& Zakrisson, 1974) and contraction force studies (Teig, 1972a). The physiological closed loop situation implicates, in this case, that when the middle ear muscles are activated, attenuation occurs, resulting in a diminished sound level. As a result the action of the muscles might be adjusted to this lower level as was shown in Figure 6.4 curve b, ultimately resulting in a steady state. Secondly, measurements were performed only up to $107 \mathrm{dBSPL}$ for most frequencies. This was done because measurements took many hours and had appeared to result in inner ear damage at higher sound levels in pilot studies. Finally, our data were derived from contralateral activation of the middle ear muscle reflex. Activation of the reflex might occur at lower intensities and can result in higher attenuation when stimulated ipsilaterally or bilaterally.

As regards the stimulus intensity-attenuation curves, it was shown that the largest effect occurred between 65-77 dBSPL. Further increase of the stimulus intensity did not result in a larger increase of attenuation. This could possibly be explained by finding of Teig (1973) who showed in the cat that stronger contractions gave less reduction of sound transmission per gram tension. In summary it seems that the maximum possible attenuation is about $15 \mathrm{dBSPL}$.

The finding that tones of $1 \mathrm{kHz}$ are attenuated most is difficult to explain. In most animals attenuation is maximal at lower frequencies and decreases towards higher frequencies. Probably, for the rat, $1 \mathrm{kHz}$ is a frequency that needs attenuation, possibly to avoid masking of higher tones. In addition it appeared that the higher tones were the most effective elicitor of the middle ear muscle reflex. This might indicate the importance of high tones for the rat. Sensitivity studies of the $\mathrm{CM}$ in the rat have shown a maximum sensitivity at $3 \mathrm{kHz}$ and 40 $\mathrm{kHz}$ (Crowley \& Hepp-Reymond, 1966). However in the Lewis rat we found a maximum sensitivity at $1.5 \mathrm{kHz}$ (Fig. 6.3c). This seems to be paradoxal since attenuation is most at $1.0-1.5 \mathrm{KHz}$. In summary, the acoustic reflex in the rat shows to be fast reactive both in latency and 
rise time. The attenuation of $0.25-8 \mathrm{kHz}$ in a closed loop system with an opened bulla using contralaterall stimulus intensities upto 115 dBSPL is limited to a mean maximum of $15 \mathrm{dBSPL}$. The tones above $1.5 \mathrm{kHz}$ appear to be the best elicitor of the middle ear muscle reflex. However, relevant interindivudual differences appear to exist. $1 \mathrm{kHz}$ appears to be attenuated the most in the rat, the reason of which remains obscure. Besides this phenomenon, interesting aspects for further research into the function of the middle ear muscles would be the separate measurement of the contributions of the stapedius and tensor tympani muscles, the fatiguability of the reflex, as well as the activity of the muscles following noise exposure.

\section{Acknowledgements}

We thank V. Bongers \& G. ter Riet for their contributions to the experiments and J. Huntjes for the technical assistance.

This study was supported by the Heinsius-Houbolt foundation. 


\subsection{References}

Berge, H. van den \& Wirtz, P. (1989a). Detailed morphology of the tensor tympani muscle of the rat. An integrated lightmicroscopical, morphometrical, histochemical, immunohistochemical and electron microscopical study in relation to function. Journal of Anatomy 164, 215-228.

Berge, H. van den \& Wirtz, P. (1989b). Detailed morphology of the stapedius muscle of the rat. An integrated lightmicroscopical, morphometrical, histochemical, immunohistochemical and electron microscopical study in relation to function. Journal of Anatomy 166, 157-166.

Berge, H. van den \& Wal, J.C. van der (1990). The innervation of the middle ear muscles of the rat. Journal of Anatomy (in press).

Borg, E. (1968). A quantitave study of the effect of the acoustic stapedius reflex on sound transmission through the middle ear of man. Acta Otolaryngologica $66,461-472$

Borg, E. \& Zakrisson, J.-E. (1974). Stapedius reflex and monaural masking. Acta Otollaryngologica $78,155-161$.

Borg, E., Counter, S.A. \& Rösler, G. (1984). Theories about middle ear muscle function. In: The acoustic reflex; Basic principles and clinical applications (ed. S. Silman). Otlando, Florida: Academic Press.

Bosatra, A., Russolo, M. \& Silverman, C.A., (1984). Acoustic-reflex latency: State of the art. In: The acoustic reflex; Basic principles and clinical applications (ed. S. Silman). Orlando, Florida: Academic Press.

Crowly, D.E. \& Hepp-Reymond, M.C. (1966). Development of cochlear function in the ear of the infant rat. Journal of Comparative and Physiological Psychology $62,427-432$.

Eliasson, S. \& Gisselsson, L. (1955). Electromyographic studies of the middle ear muscles of the cat. EEG Clinical Neurophysiology 7, 399-406.

Fisch, U. \& Schulthess, G. von (1963). Electromyographic studies on the human stapedial muscle. Acta Otolaryngologica 56, 287-297.

Horner, K.C. (1986). The tensor tympani muscle reflex in the mouse. Hearing Research 24, 117-123.

Metz, O. (1946). The acoustic impedance measured on normal and pathological ears. Acta Otolaryngologica, Suppl. 63, 1-254.

Møller, A.R. (1965). An experimental study of the acoustic impedance of the middle ear and its transmission properties. Acta Otolaryngologica 60, 129-149.

Teig, E. (1972a). Force and contraction velocity of the middle ear muscles in the cat and the rabbit. Acta Physiologica Scandinavica 84, 1-10. 
Teig, E. (1972b). Tension and contraction time of motor units of the middle ear muscles in the cat. Acta Physiologoica Scandinavica 84, 11-21.

Teig. E. (1973). Differential effect of graded contraction of middle ear muscles on the sound transmission of the ear. Acta Physiologica Scandinavica 88, 382391.

Wersall, R. (1958). The tympanic muscles and their reflexes. Acta Otolaryngologica, Suppl: $139,1-112$.

Wever, E.G \& Bray C.W. (1937). The tensor tympani muscle and its relation to sound conduction. Annals of Otology 46, 947-961.

Wever, E.G \& Bray C.W. (1942). The stapedius muscle in relation to sound conduction. Journal of experimental Psychology $31,35-43$.

Zakrisson, J.-E. (1979). The effect of the stapedius muscle reflex on attenuation and poststimulatoy fatigue at different frequencies. Acta Otolaryngologica, Suppl. 360, 118-121. 


\section{CHAPTER 7}

\section{General discussion and conclusions}

The general theory is that the function of the middle ear muscles in the auditory system is to prevent desensitivation, interference and injury. For man, the two most important aspects deduced from this theory are considered to be the protection of the inner ear against noise, and the improvement of the perception of speech in noise and during own vocalisation. However, several questions concerning these theories are not yet solved, such as:

- How do the middle ear muscles exert their function in the biomechanical system of the middle ear?

- What is the effect of contraction of the muscles on sound transmission?

- Are the muscles able to exert their function fast?

- Are the muscles able to exert their function for longer periods of time?

To answer these questions an integrated insight into the form and function of the middle ear muscles was desired. The aim of this study was to create such an integrated insight for the middle ear muscles of the rat. In this chapter, the results of the anatomical studies (Chapter 2-5) and the electrophysiological study (Chapter 6) will be discussed in the light of these successive questions. In addition, the possible consequences for the function of the muscles in the protection against noise and improvement of the perception of speech in man will be discussed. 
How do the muscles exert their function in the biomechanical system of the middle ear?

The microscopical structure and the gross anatomy of the muscles have shown that both muscles exert an almost isometric contraction pattern (Chapter 3 and 4). Several observations support this concept. In the tensor tympani muscle the muscle fibres are attached to the tendon obliquely (unipennate), which will diminish the amplitude of motion at the insertion side. Electron microscopically, bundles of myofilaments which interconnect with other bundles were observed, a feature not found in other skeletal muscles. It seems therefore that on contraction of the muscle, in addition to longitudinal forces, transverse forces are also being developed. In addition, since the main part of the muscle is not covered by bone and a large part of the muscle is connected to the bony semi-canal by a loose connective tissue, the angle between the muscle fibres and the tendon will become more obtuse upon contraction. This feature, which is observed in vivo, will result in less motion at the insertion site. Finally, the low mobility of the ossicular chain and the tympanic membrane restricts the possible amplitude of motion too.

The stapedius muscle, which is situated in a bony cavity, showed to be an circumpennate muscle with a tendon that is situated paracentrally. This configuration will also limit the range of action and will also result in a nearly isometric contraction pattern. Considering the fragile position of the stapes in the oval window niche an isometric contraction pattern is indicated.

On the basis of the three-dimensional reconstruction of the tympanic membrane / ossicular chain / middle ear muscles complex (Chapter 2) it was deduced that on contraction of the tensor tympani muscle a medially oriented force on the malleus will be developed, probably resulting in a compression in the incudo-stapedial joint. On contraction of the stapedius muscle the stapes will be tilted in the oval window niche, resulting in a translation in the incudo-stapedial joint and a compression in the malleo-incudal joint. This analysis strongly suggests that the muscles will act synergistically in increasing the stiffness of the ossicular chain and thereby in attenuating sound transmission. 
What is the effect of contraction of the muscles on sound transmission?

The electrophysiological study (Chapter 6) showed that the effect on sound transmission, as a result of the increased stiffness of the ossicular chain, is an attenuation of a mean maximum of $15 \mathrm{~dB}$, with relatively large interindividual differences. This attenuation was shown to be the result of contraction of both muscles. Compared to prior studies in man, in which only the stapedius muscle is thought to be active in the acoustic reflex, an attenuation of $15 \mathrm{~dB}$ seems to be relatively small, since in these studies attenuation up to 20-30 dB have been found. An important difference with this study in the rat is; however, that measurements were done in a closed loop system, in contrast to the measurements in most human studies, where measurements were done in an open loop system. In the, more physiological, closed loop system a regulation of the contraction of the middle ear muscles by the cochlea is still possible. When loud sound reaches the inner ear and the middle ear muscles contract, the percepted sound will be attenuated which will result in an adjustment of the contractions of the muscles to a lower level. In this way the ultimate attenuation could be less than in an open loop system, which exists for example with paralysis of the muscles. One would like to know what the role of the muscles themselves is in this process of adjustments. As in normal. skeletal muscle one would expect the muscles to be able to influence contraction by proprioceptive information from the muscles themselves or from (connective) tissue directly surrounding the muscles. However, in the study of the innervation of the muscles and the complete tympanic bulla (Chapter 5) no substrate for any sensory innervation was found, neither in the muscles themselves or in the surrounding connective tissue, or in the connective tissue elements around the ossicular chain. This would indicate that there is no afferent information from the middle ear muscles themselves or from the surrounding tissues that contributes to the acoustic reflex. The input for the afferent loop of the acoustic reflex is sound, in contrast to the situation in normal skeletal muscle reflexes, where proprioceptive information from the muscles themselves forms the afferent loop. Furthermore the absence of a sensory substrate implicates that the reflex cannot be modulated either by proprioceptive information from the muscles, or from surrounding tissues. Thus the muscles themselves 
do not seem to have a role in the above mentioned process of adjustments in the extent of the contraction of the muscles.

The influence of contraction of the muscles on the transmission of various frequencies appeared to be selective. It was shown that the effect of contraction was mainly attenuation of lower tones, i.e. around $1 \mathrm{kHz}$ and below, while the best elicitor of the reflex proved to be the higher tones. This frequency-selective attenuation of lower tones might be important for the prevention of the masking effect of these tones on higher ones. This might be important for the hearing of the rat. However to interprete this phenomenon, one would like to know more about the importance of various frequencies for hearing in the rat. In man, in whom a similar frequency-selectivity has been demonstrated, it has already been suggested that in this way the understanding of speech could be improved. This would especially occur in the understanding of speech during own speech and in (low frequency) noise. This would maintain the sensitivity of the ear for sounds during own vocalisation, swallowing etc.

Are the muscles able to exert their function fast?

On the basis of the histochemical study of the muscle fibres of both muscles (Chapter 3-4) it was shown that the muscles are able to contract fast. In both muscles the majority of the muscle fibres could be classified as fast twitch fibres (IIA fibres). Only a small proportion of the muscle fibres proved to be slow oxidative glycollytic fibres. With the immunohistochemical stainings with anti heavy chain myosin antibodies, it was also shown that the majority of the fibres were of the fast twitch type, but unlike normal adult skeletal muscles, e.g. of the extremities, many of the fibres reacted positively with both the anti IIA and anti IIB antibodies. Moreover, about one third of the fibres reacted positively with the anti neonatal antibody and one third reacted positively with the type I antibody (=slow-twitch). In addition, it was shown that several heavy chain myosins were present within one muscle fibre, even in what would appear to be a rather well differentiated striated muscle fibre of the tensor tympani. Thus, the fibres do contain the adult myosin types, but in contrast to skeletal muscles of the extremities they are found together in one fibre. Supposedly, genes coding for the various myosin heavy chains continue to be activated, 
and possibly do so in different nucleil that are contained in the syncytium. During normal postnatal development gene activation and inactivation is a regular feature which, among others, regulates the successive production of myosin isotypes such as embryonic, neonatal, slow and fast. But in this case the co-occurrence of several myosin iso-types in a muscle fibre merely indicates a transitional situation. There are no indications that such a situation exists in the middle ear muscle we studied. The biological significance of the coexpression of different myosin fibres in well differentiated muscle fibres therefore remains enigmatic. Despite this atypical observation it is likely that on the basis of the enzyme histochemical and immunohistochemical study the muscles are able to contract fast.

Electrophysiologically, the speed of contraction can be expressed by the rise time of the reflex, here defined as the time between the beginning of the contraction of the muscles and the maximal effect on the transmission of sound, measured at the level of the cochlea. The electrophysiological study (Chapter 6) has shown that the rise time of the reflex was very short, i.e. 6.6 tot $11.7 \mathrm{msec}$. These values represent the rise time of both muscles together, since both the tensor tympani and the stapedius muscle were shown to be active in the acoustic reflex in the rat. These short rise times of the reflex confirm the histochemical concept of the middle ear muscles being able to contract fast.

Another important factor that determines how fast the muscles can exert their function is the latency of the reflex. The study of the innervation of the muscles (Chapter 5) has shown that the motor innervation of the muscles is well organised. The motor endplates, which in both muscles are organised in a regular pattern, are connected to relatively short small nerve fibres. Electron microscopically, the surface area of the post-synaptic membrane of the stapedius muscle proved to be much larger than that of the tensor tympani muscle and its post-synaptic area contained more mitochondria. This could indicate a faster activation of the muscle fibres and possibly a shorter refractory period, because of a larger amount of acetylcholine esterase for the stapedius muscle. Indeed, the latency of the stapedius muscle has shown to be shorter than that of the tensor tympani muscle in various mammals.

The electrophysiological study (Chapter 6) has shown that the latency of the middle ear muscle reflex, measured at the level of the cochlea by cochlear microphonics (CM), is relatively short, i.e. varying from 
about $13 \mathrm{msec}$ to $22 \mathrm{msec}$, depending on the stimulus intensity. The latency of the tensor tympani muscle determined by EMG recordings proved to be as short as 7 msec at higher stimulus levels. The different values in the two methods of measurement can be explained by the time needed for the muscles to influence the biomechanical system of the ossicular chain. The values are much lower than the latency of $50-100$ msec measured by impedance recordings in human. One would therefore like to know the latency of the reflex measured by electrocochleography in man, to find out whether this effect is due to methodological differences or to interspecies variability.

In summary, the morphological observations indicate that the muscles are prepared for fast functioning. They should both be able to react fast and to contract fast. Both features were confirmed by the electrophysiological study.

Are the muscles able to exert their function for longer periods of time?

The enzyme histochemical study of the muscles (Chapter 3 and 4) showed that all muscle fibres of both muscles contain relatively large amounts of Gpox, indicating a high fatigue resistance. The distribution of the formazan stain in the Gpox staining showed to be atypically patchy, which proved to be caused by an irregular distribution of mitochondria on electron microscopical investigation of the muscle fibres. In several fibres large subsarcolemmal mitochondria were distributed often in clusters. Also long and elaborate interfilamentous mitochondria were found that easily spanned the length of a sarcomere, while other regions of the fibres were almost lacking in mitochondria. Electron microscopy furthermore showed numerous blood vessels indicating rich blood supply. This, together with the high amount of GPox in all muscle fibres, suggests that the muscles are prepared for long term activity. In man, however, there has been evidence of a certain fatiguebility of the acoustic reflex. This phenomenon would occur especially when the ear is exposed to continuous tones for longer periods of times. Small alterations of stimulus intensity or frequency of the sounds would reactivate the reflex. In the rat, we could not find evidence of fatiguebility during the electrophysiological experiments, which most times lasted for many hours. However, in the electrophysiological study (Chapter 6) the ear was not exposed continuously to 
loud sound. On the basis of the morphological findings in the rat the process of fatigue is more likely to be caused by neural factors, rather than by factors in the muscles themselves. Specific studies investigating this aspect and the effect of noise on the functioning of the reflex in the long term are desirable.

In summary, the muscles are likely to influence sound transmission by increasing the stiffness of the ossicular chain. In doing so, the muscles act synergistically and function as motor end organs, i.e. without the possibility of a proprioceptive feedback loop.

The amount of attenuation seems to be limited in the (physiological) closed loop system. However, the larger amount of attenuation that has been found in man has been determined in an open loop system, which might explain the lower values found in the rat. Therefore, it would be desirable to know the attenuation in man in the (physiological) closed loop situation. The interindividual differences that were found in the amount of attenuation suggest that in certain individuals the protective role of the reflex is better than in others. Regarding this aspect, it has already been suggested that before allowing persons to work in an noisy environment with the risk of a noise induced hearing loss, as well as audiometry, the individual function of the middle ear muscle reflex should be assessed and checked regularly.

The selective attenuation of frequencies supports the theory that the middle ear muscles act to maintain the sensitivity of the ear during own vocalisation etc. This from a evolutionary point of view attractive theary could explain the difference in function of the reflex between the various species. The middle ear muscle reflex would be adjusted to the special needs of the species. On the basis of this evolutionary point of view the noise protection theory has been rejected by several investigators. The main argument for this was that in nature sounds are not that loud and therefore protection is not needed. However, it should be noted that noise made by the animal or man themselves, or noise very close to the outer ear can be very loud $(130 \mathrm{~dB})$ and a protection of the inner ear can be useful.

The latency and rise time of the reflex are other important characteristics for the functioning of the middle ear muscle reflex. These characteristics would especially be important for a protective role of the reflex against noise, but also this might be important in various species in maintaining the sensitivity of the inner ear for environmen- 
tal sounds which warn them of danger. This morphological and electrophysiological study of the middle ear muscles of the rat showed that the muscles are able to react and contract fast with great endurance which make them very suitable to play an important role in both functions. However, for man, in this industrial era there are dangerous sounds, which are very loud and have very fast rise times, so that even this ingenious input control mechanism might not be able to protect the inner ear fast enough. To evaluate this, a study that investigates the effectiveness of the middle ear muscle reflex in different types of noise and the effect of noise on the middle ear muscle reflex itself in the long term, would be desirable. 


\section{CHAPTER 8}

\section{Summary}

In the first Chapter a historical review and the current theories concerning the function of the middle ear muscles are presented. From the studies in the past it became clear that the middle ear muscle reflex is an input control mechanism for the inner ear. In most mammals the tensor tympani and stapedius muscles are activated reflexively by sufficiently loud acoustic stimuli. Next to the acoustic stimuli, other stimuli such as yawning, certain tactile stimuli and the intention of production of speech have proven to elicit the middle ear muscle reflex. However, the acoustic stimuli seem to be the main elicitor of the muscles, hence the term acoustic reflex. On contraction of the muscles the biomechanical system of the ossicular chain is influenced, resulting in an attenuation of sound transmission to the inner ear. This mechanism would prevent the inner ear from over stimulation. In the past this has led to two interesting theories about the function of the middle ear muscles. They would prevent the inner ear from noise damage and they would improve the perception of speech especially during vocalisation and in noise. However, several objections have been made. The reflex would be to slow to protect against impact noise. Secondly, a process of fatigue of the reflex would occur rapidly. Finally, the amount of attenuation would be small and limited to the lower frequencies.

This problem has led to several concrete questions such as: How do the muscles exert their function in the biomechanical system of the middle ear? What is the effect of contraction of the muscles on sound transmission? Are the muscles able to exert their function fast? Are the muscle able to exert their function for longer period of time? 
To find clues to these questions an integrated study in morphology and function of the muscles was desired, the first results of which are presented in this thesis concerning the rat.

In Chapter 2, graphic three dimensional reconstructions of the tympanic bulla of the rat were made. This was done to gain insight in the topographical anatomy of the middle ear of the rat and to study the biomechanical system of the ossicular chain middle ear muscle complex in detail. For this purpose 85 drawings (i.e. one drawing every 50 $\mu \mathrm{m}$ ) of sections of complete tympanic bullae were fed into a computer. With the help of the computer the various anatomical structures could be mounted upon each other for reconstruction. In this way the topographical anatomy of the stuctures could be studied from different angles. Finally, plastic graphical representations were made by the medical artist. In this way the topographical anatomy of the tympanic bulla is visualised. It was concluded that on the basis of the topographical anatomy, the muscles are likely to act synergistically in increasing the stiffness of the ossicular chain.

In Chapter 3 various morphological aspects of the tensor tympani were studied. Several atypical characteristics compared to normal skeletal muscles were found. The muscle was composed of relatively small muscle fibres which were shaped irregularly. Electron microscopically, bundles of myofilaments branched to connect to other bundles of myofilaments. The enzyme histochemical stainings proved the muscle to be mainly composed of type IIA fibres. A small part of the muscle fibre population proved to be slow twitch, however, since these fibres showed both high SDH and GPox content they could not be classified as the classical type I fibres. Discrepancies were found when anti heavy chain myosin antibodies were used for fibre typing. Different adult heavy chain myosins isotypes coexisted in one single muscle fibre. In general, the muscle proved to be organised to perform an isometric contraction pattern, with the possibility of a fast contraction pattern and with a high fatigue resistance.

Chapter 4 presents an analogous morphological study of the stapedius muscle. This very small circumpennate muscle proved to be arranged to have an isometric contraction pattern also. Based on the morphological findings, the ultimate contraction force was likely to be smaller than that of the tensor tympani muscle. It is postulated that this does not necessarily implicate a less important influence on sound transmission. The contraction pattern was fast-twitch since the majority of the 
muscle fibres were IIA fibres. All fibres showed high resistance to fatigue. As in the tensor tympani muscle, different adult heavy chain myosins coexcisted within one muscle fibre. In conclusion, this muscle also showed several atypical morphological characteristics compared to normal skeletal muscles. It is equipped to contract fast with high endurance.

Chapter 5 describes the morphological substrate of the innervation of both middle ear muscles. The gross innervation of the muscles and the relations to other nerves in the tympanic bulla are described. It was shown that both muscles are innervated by very thin nerve fibres. These fibres form a well organized elaborate network of nervous tissue in both muscles, with very short branches that connect with the motor endplates. Electron microscopically the endplates in the stapedius muscle seemed to be prepared for a faster activation of the muscle fibres than the tensor tympani muscle. No morphological substrate for any sensory innervation of the muscles could be detected, neither in the muscles themselves, nor in the tissues surrounding the muscles. It is postulated that the muscles act as motor end organs and that afferent information from the muscles themselves is not important for the function of the acoustic reflex.

Chapter 6 presents the results of an electrophysiological study of the middle ear muscle reflex. During Vetalar ${ }^{\text {(3) }}$ anaesthesia the rise time, the latency and the influence of the acoustic reflex on sound transmission were studied. This was done by measurements of the cochlear microphonics (CM) and the electromyograms (EMG) of the tensor tympani muscle. It was shown that both the tensor tympani and the stapedius muscle are active in the reflex. The rise time of the reflex proved to be very short (min. value: $6.6 \mathrm{msec}$ ). The latency of the reflex was short too, compared to other mammals. The shortest latency of the reflex determined by recordings of the $\mathrm{CM}$ was $11.6 \mathrm{msec}$, while the mean latency of the tensor tympani muscles measured by EMG was about $7 \mathrm{msec}$. The attenuation of $0.25-8 \mathrm{kHz}$ tone burst of 115 $\mathrm{dBSPL}$ is limited to a mean maximum of $15 \mathrm{~dB} .1 \mathrm{kHz}$ was shown to be attenuated the most. The tones above $2 \mathrm{kHz}$ appeared to be the best elicitors of the middle ear muscle reflex. Relatively large interindividual differences were found.

In Chapter 7 the results of the five separate studies are integrated and discussed in the light of the questions stated in the introduction (Chapter 1). 


\section{Samenvatting}

In het eerste hoofdstuk wordt een historisch overzicht gegeven van het tot op heden verrichte onderzoek naar de functie van de middenoorspieren. Hieruit blijkt dat de middenoorspier reflex een belangrijk input controle mechanisme van het binnenoor vormt. Bij de meeste zoogdieren worden de musculus tensor tympani en de musculus stapedius reflexmatig geactiveerd door voldoende luide acoustische stimuli. Behalve geluidsprikkels kunnen ook andere prikkels zoals gapen, bepaalde tactiele prikkels en de intentie tot spreken de middenoorspierreflex activeren. De belangrijkste stimulus blijkt echter de acoustische stimulus te zijn. Wanneer de spieren tot contractie worden gebracht wordt het biomechanische systeem van trommelvlies-gehoorbeenketen-complex beinvloed, resulterend in een vermindering van de geluidstransmissie naar het binnenoor. Bepaalde geluidsfrequenties kunnen hierbij zelfs versterkt worden. Dit mechanisme zou het binnenoor beschermen tegen over-stimulatie. In het verleden heeft deze veronderstelling geleid tot twee interessante theorieèn over de functie van de middenoorspieren. Zo zou het binnenoor door de reflex worden beschermd tegen lawaaibeschadiging en zou het spraakverstaan door de reflex worden verbeterd, dit laatste met name tijdens het zelf foneren en in het verkeren in een lawaaierige omgeving. Er zijn echter verscheidene bezwaren tegen deze theorieên aangevoerd. De reflex zou te langzaam zijn om bescherming te kunnen bieden tegen de invloed van plotseling lawaai. Bovendien zou de reflex snel vermoeibaar zijn. Tenslotte zou de mate van demping klein zijn en beperkt blijven tot de lagere tonen. Teneinde meer inzicht hierin te verkrijgen moet een antwoord worden gezocht op de volgende vragen: Hoe beinvloeden de middenoorspieren het biomechanische systeem van het middenoor? Wat is het effect van contractie van de spieren op de geluidstransmissie? Kunnen de spieren snel hun functie vervul- 
len? Kunnen de spieren over langere perioden hun functie vervullen? Om deze vragen te kunnen beantwoorden was een geintegreerde studie in de morfologie en de functie van de spieren in één en dezelfde species gewenst, hetgeen heeft geleid tot de onderhavige studie bij de rat.

In Hoofdstuk 2 wordt de topographische anatomie van de bulla tympanica met nadruk op het biomechanische systeem van gehoorbeenketen en middenoorspieren van de rat beschreven. Dit word gedaan aan de hand van driedimensionale grafische reconstructies. Om deze reconstructies te verkrijgen werden 85 tekeningen van coupes (dwz om de 50 $\mu \mathrm{m})$ van hele bullae ingevoerd in de computer. Op deze wijze konden de verschillende onderdelen van de bulla worden gereconstrueerd en van alle kanten worden bestudeerd door het aanzicht met behulp van de computer te veranderen. Met behulp van deze computer reconstructies konden door de medisch tekenaar plastische presentaties worden gemaakt. De topografische anatomie van de bulla tympanica wordt zo gevisualiseerd. Op grond van de reconstructies lijkt het aannemelijk dat de middenoorspieren een synergistisch effect hebben op het vergroten van de stijfheid van de gehoorbeenketen.

In het derde hoofdstuk worden de resultaten van de gedetaileerde morfologische studie van de musculus tensor tympani van de rat beschreven. De spier blijkt in vergelijking met de normale skeletspieren een aantal bijzondere morfologische kenmerken te bezitten. De musculus tensor tympani is opgebouwd uit relatief kleine, onregelmatig gevormde spiervezels. Uit electronenmicroscopisch onderzoek van de spiervezels blijkt dat bundels myofilamenten zich vertakten en een verbinding vormden met ander bundels myofilamenten. De enzymhistochemische kleuringen tonen dat de spier hoofdzakelijk bestaat uit IIA vezels. Een klein deel van de spiervezels is slow-twitch, maar aangezien deze vezels zowel een hoge activiteit van SDH als GPox toonden, kunnen ze niet worden gerekend tot de klassieke type I vezel. Bij de vezeltypering met behulp van monoclonale anti heavy chain myosine antilichamen werden discrepanties gevonden. Verschillende volwassen heavy chain myosine isotypes komen samen in spiervezels voor, een fenomeen dat in de gewone skeletspier van de rat niet werd gevonden. Samenvattend wordt op grond van dit morfologisch onderzoek geconcludeerd dat de spier waarschijnlijk een isometrisch contractiepatroon heeft, waarbij de spier tot snelle contractie in staat moet worden geacht, gepaard gaande met een relatief grote onvermoeibaarheid. 
In Hoofdstuk 4 worden de resultaten van een analoge studie van de musculus stapedius besproken. Deze bijzonder kleine circumpennate spier vertoont waarschijnlijk eveneens een isometrisch contractiepatroon. Op grond van de morfologische bevindingen zal de contractiekracht kleiner zijn dan die van de musculus tensor tympani. Er worden argumenten gegeven waarom dit niet hoeft te betekenen dat de musculus stapedius dan ook een geringere invloed op de geluidstransmissie heeft. De spiervezels blijken voor het merendeel van het type MA te zijn, een indicatie voor een snel contractiepatroon en een relatieve onvermoeibaarheid. De spier zou dus in staat moeten zijn snel en gedurende langere tijd te kunnnen contraheren. Tenslotte laat ook deze spier verscheidene bijzondere atypische morfologische kenmerken zien vergeleken met gewone skeletspieren, zoals bijvoorbeeld de aanwezigheid van verschillende volwassen typen heavy chain myosines binnen een spiervezel.

In Hoofdstuk 5 worden de resultaten van de studie naar de morfologische grondslag van de innervatie van beide middenoorspieren beschreven. De innervatie van de spieren en de relatie met andere zenuwen in de bulla tympanica worden beschreven. De zenuwvezels vormen in beide spieren een nauw omschreven netwerk van zenuwweefsel. Zeer korte vertakkingen vormen de verbindingen met de motorische eindplaatjes. Electronenmicroscopisch lijken de eindplaatjes van de musculus stapedius een snellere activatie van de spiervezels mogelijk te maken dan bij de tensor tympani. Voor een sensorische innervatie kon geen morfologische basis worden gevonden, noch in de spieren zelf, noch in het bindweefsel direct rond de spieren, noch in de bulla tympanica. Verondersteld wordt dat de spieren dienen als motorische eindorganen en dat aanvoerende informatie van de spieren zelf de middenoorspierreflex beinvloed.

In Hoofdstuk 6 worden de resultaten van een electrofysiologisch onderzoek naar de middenoorspierreflex van de rat besproken. Gedurende algehele narcose door middel van Vetalar werden de contractie tijd, de latentietijd en de invloed van de reflex op de geluidstransmissie onderzocht. Dit gebeurde door middlel van metingen van de cochleaire microfonie (CM) en electromyografie (EMG) van de musculus tensor tympani. Het blijkt dat, in tegenstelling tot wat gedacht wordt bij de mens, zowel de musculus tensor tympani als de musculus stapedius consequent worden geactiveerd door acoustische stimuli. De contractietijd van de spieren samen blijkt zeer kort te zijn, te weten minimaal 6,6 
msec. Ook de latentietijd van de reflex is kort vergeleken bij die van andere zoogdieren. De kortste latentietijd van de reflex, bepaald middels de CM was $11,6 \mathrm{msec}$, terwijl de gemiddelde latentietijd van reflex response van de musculus tensor tympani, gemeten middels EMG ongeveer $7 \mathrm{msec}$ is. De demping van $0,25-8 \mathrm{kHz}$ toon-bursts van $115 \mathrm{dBSPL}$ blijkt bij metingen bij zes ratten maximaal gemiddeld $15 \mathrm{~dB}$ te zijn. Het effect op de geluidstransmissie is het grootste bij $1 \mathrm{kHz}$. De middenoorspierreflex blijkt het beste te worden geactiveerd door frequenties boven de $2 \mathrm{kHz}$. Er blijken relatief grote interindividuele verschillen te bestaan met name ten aanzien van de mate van het dempend effect.

In het laatste hoofdstuk wordt getracht de in de inleiding gestelde vragen te beantwoorden. Hiertoe worden de bevindingen uit de verschillende hoofdstukken geintegreerd en besproken. 


\section{Nawoord}

Met genoegen wil ik hier stilstaan bij al diegenen die hebben bijgedragen aan de totstandkoming van dit proefschrift.

Veel dank ben ik verschuldigd aan mijn promotor Prof. Dr. E.H.M.A. Marres. Beste Ed, ik ben erg trots om als eerste bij jou te mogen promoveren. Je grote belangstelling voor en actieve participatie aan het onderzoek en vooral ook het creëren van een uitermate plezierig werkklimaat heb ik zeer gewaardeerd.

Promotor Prof. Dr. J. Drukker wil ik graag bedanken voor het bieden van de gewenste faciliteiten op de afdeling AnatomieLEmbryologie. Uw constructieve suggesties bij het schrijven van de artikelen en het proefschrift zijn van grote waarde geweest.

Co-promotor Dr. H. Kingma, beste Herman, jij was mijn steun en toeverlaat de afgelopen jaren. Onze wekelijks terugkerende werkbesprekingen tijdens het hardlopen zal ik niet gauw vergeten. Adembenemende ideeën zagen dan het licht en onze discussies scherpten de gedachten. Je niet aflatend optimisme is een grote inspiratie geweest.

Dr. F.I.R.C.S de Jong, amice Felix, jij stond met het "ontdekken" van de middenoorspieren aan de wieg van dit onderzoek en hebt mij met je wetenschappelijk enthousiasme op het goede spoor gezet. In samenwerking met Dr. P. Wirtz (destijds afdeling Cytologie en Histologie, KUN) werd het project van de grond getild. Beste Peter, in die zo belangrijke eerste fase stond jij altijd weer klaar voor het onderzoek ondanks de drukke en moeilijke periode waarin jij toen verkeerde. Bovendien wist je steeds opnieuw die belangrijke analistische ondersteuning te organi- 
seren. Jouw nauwgezette en geduldige adviezen t.a.v. het op papier zetten van de resultaten waren van grote waarde. Ik heb dit alles zeer gewaardeerd. Ik wil hier bovendien graag Hélène Loermans, Luuk Lubbers en Anita van Geest bedanken voor de vele histologische werkzaamheden die zij in die periode verricht hebben. Anita van Geest, histologisch analiste, neemt onder hen een heel bijzondere plaats in. Beste Anita, het werk dat jij in een jaar tijd heb weten te verzetten en het initiatief dat je hierbij aan de dag hebt gelegd is buitengewoon geweest. Dr. P. Jap (Afd. Celbiologie, KUN) beste Paul, onze besprekingen over de elektronenmicroscopische bevindingen, alsmede het aanstekelijk enthousiasme dat je hierbij toonde, waren zeer waardevol. Dr. W. Kuipers (Afd. KNO Heelkunde, KUN), beste Wim, veel dank voor je nuttige adviezen en actieve bijdragen die je verschillende malen aan het onderzoek hebt geleverd.

Een groot deel van het onderzoek heeft uiteindelijk plaats gevonden op de afdeling Anatomie en Embryologie van de Rijks Universiteit Limburg (Hoofd Prof. Dr. J. Drukker). Nagenoeg alle medewerkers zijn in meer of mindere mate bij het onderzoek betrokken geraakt. Een ieder ben ik hiervoor zeer erkentelijk. In het bijzonder wil ik jullie, Hans Rensema, medisch morfologisch vormgever, drs. Arno Lataster, conservator, ing. Jacques Beursgens, computerprogrammeur en Paul van Dijk, zoölogisch analist bedanken voor jullie essentiele bijdragen in raad en daad aan het onderzoek. Met name jij, Hans, hebt met jouw zeer fraaie plastische representaties van het middenoor en je vele grafische adviezen een belangrijke bijdrage aan het onderzoek geleverd. Dr. J.C. van der Wal, beste Jaap, jouw algemene bespiegelingen en adviezen inzake de innnervatie van de middenoorspieren waren heel waardevol.

De elektrofysiologische experimenten vergden veel voorbereiding en technische ondersteuning. Veel hulp bij zowel de voorbereiding als de experimenten zelf, heb ik gehad van drs. Carl Kluge, drs. Vivian Bongers en drs. Gerben ter Riet. Ing. J. Huntjens (afd. KNO Maastricht), beste John, jij bent van grote betekenis geweest voor de technische begeleiding van het onderzoek. Ook de medewerkers van de Centrale Proefdier Voorzieningen en de medewerkers van de instrumentele dienst van het Biomedisch Centrum wil ik hier graag bedanken voor hun bijdragen aan het electrofysiologisch deel van het onderzoek.

Mijn KNO-collegae, alsmede de assistentes van de poli, verpleging van $\mathrm{C} 2$ en secretaressen, die mij op de juiste momenten ontzagen en me 
regelmatig uit de brand hielpen wanneer het onderzoek me volledig opeiste ben ik veel dank verschuldigd.

Bij het op papier zetten van de resultaten heb ik vele nuttige aanwijzingen gekregen van Prof. Dr. J.W. Arends (Afd. Pathologie, AZM). Beste Jan Willem, ik wil je hiervoor alsmede voor voor de grote belangstelling die je steeds voor het onderzoek toonde van harte bedanken.

De grote hoeveelheid anatomische illustraties in dit proefschrift waren beslist ondenkbaar geweest zonder de onophoudelijke en enthousiaste inzet van afdeling Medische Fotografie van het Academisch Ziekenhuis Maastricht. Een ieder van deze afdeling wil ik hiervoor zeer bedanken. De firma Duphar Nederland B.V. ben ik zeer erkentelijk voor de financiele steun, waardoor de kleurenillustraties in het proefschrift mogelijk werden gemaakt.

Lieve Mieke, de afgelopen tijd ben ik mij er meer dan ooit van bewust geworden dat het schrijven van een proefschrift geen zaak is van de promovendus alleen. Jouw begrip, geduld en interesse waren een grote steun, zonder welke dit proefschrift niet tot stand zou zijn gekomen. 


\section{Curriculum vitae}

De schrijver van dit proefschrift werd geboren op 12 oktober 1958. In juli 1977 behaalde hij het eindexamen Atheneum B aan de Gemeenschappelijke Scholengemeenschap Woensel te Eindhoven. Zijn medische studie volgde hij aan de Rijksuniversiteit Limburg, welke op 1 juli 1983 werd afgerond met het behalen van het artsexamen. Na ruim een half jaar als arts-assistent (AGNIO) op de afdeling Algemene Heelkunde (Hoofd: Prof. Dr. J.M. Greep) van het toenmalige St. Annadal Ziekenhuis te hebben gewerkt, volgde hij de huisartsopleiding aan de Rijkuniversiteit Limburg (Huisartsopleider: dr. P. Huysmans, te Asten). Deze opleiding werd afgerond in maart 1985. Op 1 April 1985 startte hij de opleiding tot Keel-, Neus- en Oorarts (Opleider: Prof. Dr. E.H.M.A. Marres) in het Academisch Ziekenhuis Maastricht. Gedurende deze periode werkte hij gedurende drie maanden (okt-dec 1988) als senior registrar op de afdeling ENT-Surgery in het Radcliff Infirmary, Academisch Ziekenhuis van de Universiteit van Oxford, Engeland (Hoofd: W.S. Lund, MS, FRCS). Op 1 april 1989 werd de opleiding tot Keel-, Neus- en Oorarts afgerond. Vanaf die datum werkt hij als junior-staflid aan de afdeling Keel-, Neus- en Oorheelkunde van het Academisch Ziekenhuis Maastricht. 